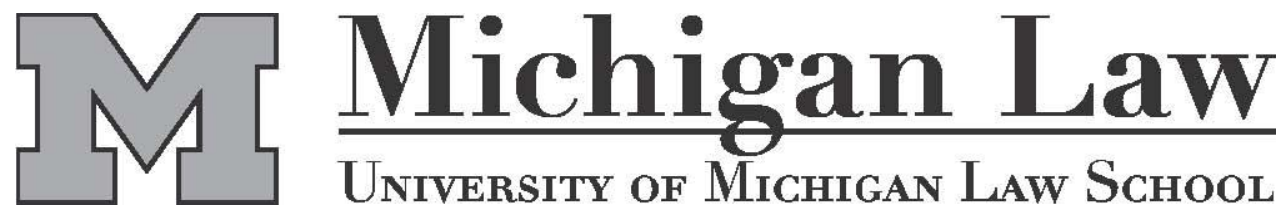

MICHIGAN

ROSS SCHOOL OF BUSINESS

Ross School of Business Working Paper Working Paper No. 1209

PUBLIC LAW AND LEGAL THEORY RESEARCH PAPER

SERIES PAPER NO. 283

SEPTEMBER 2013

\title{
CEO CONNECTEDNESS AND CORPORATE FRAUDS
}

Vikramaditya S. Khanna

\author{
E. Han Kim
}

Yao Lu

THE SOCIAL SCIENCE RESEARCH NETWORK ElECTRONIC PAPER COLLECTION:

HTTP://SSRN.COM/ABSTRACT=2323251

FOR MORE INFORMATION ABOUT THE PROGRAM IN LAW AND ECONOMICS VISIT: 


\title{
CEO Connectedness and Corporate Frauds
}

\author{
Vikramaditya Khanna, E. Han Kim, and Yao $\mathrm{Lu}^{\dagger}$
}

\begin{abstract}
This paper identifies an important factor magnifying the risk of corporate fraud - the connections CEOs develop with top executives and directors through their appointment decisions during their tenure. A sample of publicly listed firms over the period 1996-2006 reveals that appointment-based CEO connectedness within executive suites and boardrooms increases the likelihood of committing frauds and decreases the likelihood of detection. We identify three channels through which the CEO connectedness decreases expected costs of committing fraud - by helping to conceal frauds, by reducing the likelihood of CEO dismissal upon fraud discovery, and by lowering the coordination costs of carrying out illegal activities. Further, except for audit committee independence, standard monitoring mechanisms do not seem to mitigate the adverse effects on frauds. These findings suggest regulators, investors, and governance specialists should pay particular attention to appointment-based CEO connectedness.
\end{abstract}

First Draft: August 22, 2011

This Draft: September 3, 2013

Keywords: Corporate Frauds, Appointment-based CEO connections, Corporate Governance, Social Connections, CEO Power.

JEL Classifications: G30, K20

\footnotetext{
${ }^{\dagger}$ Vikramaditya Khanna is at the University of Michigan Law School, Ann Arbor, Michigan 48109: vskhanna@umich.edu. E. Han Kim is at the University of Michigan Ross School of Business, Ann Arbor, Michigan 48109: ehkim@umich.edu. Yao Lu is at Tsinghua University School of Economics and Management, Beijing, China: luyao@sem.tsinghua.edu.cn. We are grateful for helpful comments and suggestions by Campbell Harvey, the editor, an anonymous associate editor, an anonymous referee, Simon Johnson, Jeffrey Smith, seminar participants at the University of Michigan Law School and Ross School of Business, University of Southern California Law School, University of Miami Law School, Central University of Finance and Economics, Renmin University, Indian School of Business, Hyderabad, and Shanghai University of Finance and Economics and participants at the 2013 American Finance Association Meetings, the 2013 American Law and Economics Association Annual Meeting, the $7^{\text {th }}$ Conference on Empirical Legal Studies. We are indebted to Jonathan Karpoff and Gerald Martin for generously sharing their Federal Securities Regulation (FSR) database. We also thank Joseph Rewoldt, Satoko Kikuta, Guodong Chen, Paul A. Sandy, Alex Pierson, Melan A. Patel, Rudresh Singh, Tamar Groswald Ozery, Shinwoo Kang, and Robert Powell for excellent research assistance. This project received generous financial support from Mitsui Life Financial Research Center at the University of Michigan. Yao Lu acknowledges support from Project 71202020 of National Natural Science Foundation of China.
} 


\section{INTRODUCTION}

Accusations of corporate and securities fraud dominated headlines over the last decade. Corporate wrongdoing damages investor confidence, hurts shareholder value, causes misallocation of capital, and increases financial market instability, ${ }^{1}$ leading a number of scholars to examine factors affecting the likelihood of fraud and its detection. Largely absent from these inquiries, however, is the role played by the CEO's connections with other corporate leaders. ${ }^{2}$ CEOs have substantial "soft" influence along with explicit legal authority within the firm to direct corporate behavior, ${ }^{3}$ of which wrongdoing is but one potential outcome. The "soft" influence is likely to be strengthened by the CEO's internal connections.

CEO connections with other top executives and directors could increase or decrease the incidence of corporate fraud. As with other corporate activities, corporate wrongdoing often requires coordination between, or acquiescence by, top executives and/or board members. The coordination and acquiescence can be in the form of direct involvement in criminal activities or a reluctance to "blow the whistle." CEOs' close connections may help obtain the necessary support and thereby facilitate wrongdoing. However, it may also help deter frauds. The CEO’s familiarity with other top executives may enable him to detect early signs of fraud. Or when a CEO is unaware or uncertain about the illegality of certain activity, a common problem in some areas of white collar crime, closer interpersonal relationships could make it easier for other executives and board members to provide friendly information to the CEO to help avoid wrongdoing. Further, the CEO’s close connectedness could make it easier to stamp out fraud from

\footnotetext{
${ }^{1}$ See Karpoff and Lott (1993); Beatty, Bunsis, and Hand (1998); Bhagat, Bizjak, and Coles (1998); Karpoff, Lee, and Vendrzyk (1999); Bar-Gill and Bebchuk (2002); Karpoff, Lee, and Martin (2008a); Karpoff, Lee, and Martin (2008b); Gande and Lewis (2009); Murphy, Shrieves, and Tibbs (2009); and Karpoff, Lee, and Martin (2010).

${ }^{2}$ A notable exception is Chidambaran, Kedia, and Prabhala (2012), who study how CEO-board network ties are related to fraud likelihood.

${ }^{3}$ Evidence on the importance of CEO influence on firm behavior and performance includes Graham, Harvey, and Puri (2013) who show CEOs' behavioral traits such as optimism, risk-aversion, and time preference are related to corporate financial policies and managerial compensation; Bertrand and Shoar (2003) who find CEO characteristics matter for a wide range of firm policies; Bennedsen, Perez-Gonzalez, and Wolfenzon (2006) who document that CEO deaths are strongly negatively correlated with firm profitability and growth; Cronqvist, Makhija, and Yonker (2012) who show differences in corporate financial leverage can be traced to CEOs' personal leverage; and Jenter and Lewellen (2011) who find CEO age approaching retirement has an important impact on the likelihood of their firms being taken over and the takeover premiums their shareholders receive. See Allen, Kraakman, and Subramanian (2012) for discussion of CEOs' legal authority to contractually bind the firm for ordinary transactions.
} 
which the CEO does not anticipate personal gains. That is, CEO connectedness can cut both ways, and which effect prevails is an empirical question.

We consider two sources of CEO connectedness to top executives and directors: appointment decisions and prior network ties. We also examine CEO power because the power relationship with other corporate leaders may also influence fraud. Of these three possible sources of connections and influence, we find the one warranting particular attention for fraud prevention and detection is the least obvious - the fraction of top corporate leaders appointed during the current CEO’s tenure. It has strikingly strong effects on all aspects of fraud, regardless of whether the connection is built through appointments of top executives or directors. In contrast, network ties and CEO power have considerably weaker effects on fraud.

Appointment-based CEO connectedness is significantly associated with not only greater fraud likelihood, but also with lower expected costs of engaging in fraud: it decreases the likelihood of fraud detection, lengthens the time from fraud commission to its detection, reduces the likelihood of forced CEO turnover upon discovery of fraud, and lowers the coordination costs needed to carry out illegal activities. Moreover, except for audit committee independence, we find little evidence that other standard monitoring mechanisms ameliorate the impact of appointment-based CEO connectedness.

Connectedness built through appointment decisions increases what social psychologists refer to as social influence. It relies on norms of reciprocity, liking, and social consensus to shape group decisionmaking processes (Cialdini, 1984) and, hence, facilitates the acquiescence or coordination required to engage in fraud and keep it from view. When more top executives are appointed during a CEO’s tenure, the CEO’s social influence increases because CEOs are heavily involved in recruiting, nominating, and appointing top executives and in deciding their compensation. Thus, top executives are more likely to share similar beliefs and visions with, and may be beholden to, the CEO who hired or promoted them to current positions than executives appointed during a previous CEO’s tenure (Landier, Sauvagnat, Sraer, and Thesmar, 2013; Kim and Lu, 2013). CEOs also tend to be involved in recruiting board members either directly or indirectly through consultation with the nominating committee; thus, directors recruited during a 
CEO’s tenure may similarly be beholden to the CEO (Morse, Nanda, and Seru, 2011; Coles, Daniel, and Naveen, 2011).

We find CEOs’ prior network connections with top executives and directors do not facilitate fraud as effectively as appointment-based connections. CEOs’ prior network ties with top executives are mostly unrelated to fraud, and no CEO-board network ties are significantly related to the likelihood of detection. On the likelihood of fraud incidence, we find the same mixed effects identified in Chidambaran et al. (2012): Fraud probability decreases with professional connections through past employment overlaps but increases with nonprofessional social ties. We argue appointment-based connections have stronger effects on fraud than network ties because when one is appointed to a top executive position or recommended to the board by a CEO, she may feel a greater sense of loyalty to the CEO. Such a loyalty factor is likely to be weaker when the connection is through network ties. One may even argue sharing similar education or work experiences can breed a sense of competition that may not fit as comfortably with loyalty.

Our measure of CEO power follows the approaches used in previous studies: Whether the CEO chairs the board, is a founder, owns a large number of shares, and/or has served for a long time as CEO. These power variables, or their composite index, are mostly unrelated to fraud. CEO power is about the ability to exert one's own will on others - a mostly one-way influence that is easier to resist if the intended action or inaction is against the law (i.e., wrongdoing). It does not necessarily reflect the ability to encourage voluntary cooperative behavior among a group of individuals, which is often needed for fraud. Social influence arising from appointment-based connectedness, by contrast, is about two-way relationships conducive to voluntary cooperative behavior, including fraud.

Our sample covers 17,797 firm-year observations associated with 2,736 unique firms during the period 1996 through 2006. We gather comprehensive data on alleged corporate frauds and apply carefully designed screens to exclude mistaken or frivolous suits. We identify 315 fraud cases with 886 firm-year fraud observations, in which the CEO is a named respondent and data is available to construct appointment-based CEO connectedness variables. Our primary source of fraud data is the Federal 
Securities Regulation (FSR) database (Karpoff, Koester, Lee, and Martin, 2012) generously provided by Karpoff and Martin. FSR provides the most comprehensive and accurate data on financial misstatements. We include other types of fraud by supplementing FSR with fraud allegations contained in the Securities and Exchange Commission's (SEC’s) Litigation Releases and in the Stanford Securities Class Action Clearinghouse (SSCAC).

Inherent in any fraud sample is the partial observability problem: we observe detected frauds, not the population of frauds. Since observed fraud depends on two distinct but latent processes--commitment of fraud and detection of fraud--we follow Wang, Winton, and Yu (2010) and Wang (2011) and employ the bivariate probit model. We measure CEO connectedness with top executives by the fraction of the top four non-CEO executives appointed (FTA) during the current CEO's tenure; CEO connectedness with directors, by the fraction of directors appointed (FDA) during a CEO’s tenure. These fractions at a particular point in time depend on how long the CEO has been in the office. Thus, our analyses control for CEO tenure throughout the paper. For robustness, we also use abnormal fractions of top executives and directors appointed during the CEO's tenure, AFTA and AFDA, which are the residuals of regressions relating FTA and FDA to CEO tenure and other factors mechanically correlated to them.

Both measures of CEO connectedness are positively related to the likelihood of wrongdoing and negatively related to the likelihood of detection, given wrongdoing. Our estimates indicate that a firm with all four top non-CEO executives appointed during the CEO’s tenure (FTA $=1$ ) has a 29.65\% higher fraud incidence and a $27.68 \%$ lower likelihood of detection given fraud than a firm with none of the top four executives appointed during the CEO’s tenure $(\mathrm{FTA}=0)$. A firm with all directors appointed during the CEO's tenure $(\mathrm{FDA}=1$ ) has a $36.11 \%$ higher fraud incidence and a $34.09 \%$ lower likelihood of detection than a firm with no directors appointed during the CEO’s tenure (FDA $=0$ ).

An important factor in the choice of whether or not to commit fraud is the expected punishment (Becker, 1968). Thus, we also investigate channels through which CEO connectedness affects the expected costs of fraud. Closer CEO connectedness may help conceal fraud by influencing others to 
fabricate or obfuscate internal records, making it harder to detect or prove wrongdoing in court (Arlen and Carney, 1992; Khanna, 2003), or by simply pressuring individuals not to reveal instances of wrongdoing out of loyalty to the CEO who appointed them. Bivariate probit model estimates reveal FTA and FDA are negatively related to detection, given fraud. FTA and FDA also are positively related to fraud detection duration, the period from the commencement of fraudulent activity to the detection date, and negatively related to the Cox-hazard ratio of fraud detection. Our estimates imply a fraud by a firm with FTA $=1$ will take 235 days longer to be detected than a fraud by a firm with FTA $=0$, while a firm with FDA $=1$ will take 331 days longer to be detected than a fraud by a firm with FDA $=0$. CEO connectedness seems to help conceal frauds and delay their detection.

CEO connectedness may also reduce the expected cost of fraud by lowering the probability of CEO dismissal upon discovery of wrongdoing. Detected frauds do not automatically lead to forced CEO turnover. CEOs more connected to their top lieutenants and board members may garner greater support to retain their jobs. We find closer CEO connectedness is associated with lower forced CEO turnover-fraud sensitivity. Our estimates indicate that the probability of forced CEO turnover following a fraud by a firm with FTA $=1$ is $33.85 \%$ lower than that by a firm with FTA $=0$, while the turnover probability is $47.54 \%$ lower for a firm with FDA $=1$ than for a firm with FDA $=0$.

In addition, coordinating illegal activities may be less costly when CEOs are more closely connected with other corporate leaders, as they might be more willing to override internal control mechanisms or push through policies or activities that others may be reluctant to pursue (Khanna, 2003). With lower coordination costs, more people are likely to be involved in a fraud, and charged when detected. This is what we find; the number of people charged with fraud is positively and significantly related to both FTA and FDA.

Since FTA and FDA are endogenous, we estimate two-stage instrumental variable (IV) regressions. Our IVs are the death of the CEO, top executives, and directors, and an indicator of whether a 
firm's headquarters is located in a remote area. ${ }^{4}$ Deaths of the CEO, top executives, and directors automatically change FTA and FDA, but our selection criteria of deaths make them unlikely to be related to fraud. Executives in remote headquarters may turnover more due to their tendency to prefer larger cities, leading to higher FTA, but remoteness is unlikely to be directly related to fraud. The results are robust to two-stage estimations using these IVs. Our results are also robust to alternative bivariate probit model specifications, alternate measures of FTA and FDA, and an alternative fraud sample construction.

We then ask whether the adverse effects of CEO connectedness can be contained by standard governance mechanisms. We re-estimate the bivariate probit model while interacting FTA or FDA with the strength of internal monitoring by the board and the audit committee and with a proxy for external monitoring (institutional ownership concentration). Except for audit committee independence, these mechanisms do not seem effective in reducing the influence of CEO connectedness on wrongdoing.

The prior literature on corporate fraud examines the impact of board structure, ${ }^{5}$ general business conditions, ${ }^{6}$ corporate lobbying, ${ }^{7}$ market- and regulatory-based institutions, ${ }^{8}$ and executive compensation. ${ }^{9}$ We contribute to this literature by identifying an important factor magnifying the risk of corporate frauds - appointment-based CEO connectedness. Our study also helps us understand how different aspects of CEO influence affect fraud. Of three possible sources of CEO influence, the one with the most visible effects on fraud is the least noticeable; social influence enhanced through appointment decisions rather than prior network ties or CEO power.

Before detailing our analyses, a caveat is in order: Our findings do not necessarily imply appointment-based CEO connectedness is bad overall. It has many potential benefits. For example, closely-knit top executives may expedite decision-making and implementation through more effective communication and coordination, resulting in better anticipation of, and reactions to, internal and external

\footnotetext{
${ }^{4}$ We thank an anonymous associate editor for suggesting the geographic remoteness as an IV.

${ }^{5}$ See Beasley (1996), Agrawal and Chadha (2005), and Chidambaran et al. (2012).

${ }^{6}$ See Povel, Singh, and Winton (2007); Wang et al. (2010); and Wang and Winton (2012).

${ }^{7}$ See Yu and Yu (2011).

${ }^{8}$ See Dyck, Morse, and Zingales (2010).

${ }^{9}$ See Burns and Kedia (2006); Peng and Röell (2008); Hertzberg (2005); and Efendi, Srivastava, and Swanson (2007).
} 
challenges. Furthermore, greater FTA and FDA mean there are more newly-appointed top executives and directors. The new blood may help revitalize the top executive team and the board, enhancing the CEO’s productivity itself (Edmans, Goldstein, and Zhu, 2013). Unfortunately, these efficiency-related benefits of appointment-based CEO connectedness are not illuminated here because our inquiry is about a dark side of CEO connectedness - its association with fraud.

The next section contains the empirical design, data description, and summary statistics. Section III provides the main results. The channels through which CEO connectedness influences the expected cost of wrongdoing are explored in Section IV. Section V conducts additional robustness tests. Section VI investigates whether standard monitoring mechanisms ameliorate the impact of CEO connectedness. Section VII examines pre-existing network ties and CEO power. Section VIII concludes.

\section{EMPIRICAL DESIGN, DATA, AND SUMMARY STATISTICS}

\section{II.1 Empirical Methodology}

To address the partial observability issue when estimating the relation between CEO connectedness and fraud, we follow Wang et al. (2010) and Wang (2011) and employ the bivariate probit

model. For each firm $i$, we denote Fraud $_{i t}{ }^{*}$ and Detect $_{i t}{ }^{*}$ as the latent variables determining firm $i$ 's likelihood of committing a fraud in year $t$ and the possibility of detecting it as follows:

$$
\begin{aligned}
& \text { Fraud }_{\mathrm{it}}{ }^{*}=X_{\mathrm{F}, \mathrm{it}} \delta+\mu_{\mathrm{it}} \\
& \text { Detect }_{\mathrm{it}}{ }^{*}=X_{\mathrm{D}, \mathrm{it}} \eta+v_{\mathrm{it}}
\end{aligned}
$$

$X_{F}$,it is a vector of variables explaining firm $i$ 's likelihood of committing a fraud in year $t$, and $X_{D}$,it contains variables explaining the firm's likelihood of being detected. $\mu_{i t}$ and $v_{i t}$ are zero-mean disturbances with a bivariate normal distribution. The correlation between $\mu_{i t}$ and $v_{i t}$ is $\rho$. We define Fraud $d_{i t}=1$, if

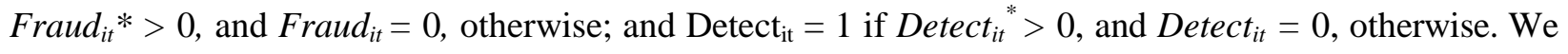
do not directly observe the realizations of Fraud $_{i t}$ and Detect $t_{i t}$; instead, we observe Observe $_{i t}=$ 
Fraud $_{i t}$ Detect $_{i t}$, where Observe ${ }_{i t}=1$ if firm $i$ has committed fraud and has been detected, and Observe $e_{i t}=0$ if firm $i$ has not committed a fraud or has committed fraud but has not been detected.

Let $\Phi$ denote the bivariate standard normal cumulative distribution function. The empirical model for Observe it $_{\text {is: }}$

$$
\begin{aligned}
& \left.\mathrm{P}_{\left(\text {Observe }_{\mathrm{it}}\right.}=1\right)=\mathrm{P}\left(\text { Fraud }_{\mathrm{it}} \text { Detect }_{\mathrm{it}}=1\right)=\Phi\left(\mathrm{X}_{\mathrm{F}, \mathrm{it}} \delta, \mathrm{X}_{\mathrm{D}, \mathrm{it}} \eta, \rho\right) \\
& \left.\mathrm{P} \text { Observe }_{\mathrm{it}}=0\right)=\mathrm{P}\left(\text { Fraud }_{\mathrm{it}} \text { Detect }_{\mathrm{it}}=0\right)=1-\Phi\left(\mathrm{X}_{\mathrm{F}, \mathrm{it}} \delta, \mathrm{X}_{\mathrm{D}, \mathrm{it}} \eta, \rho\right)
\end{aligned}
$$

Thus, the log-likelihood function for the model is:

$$
\mathrm{L}(\delta, \eta, \rho)=\Sigma \log \left(\mathrm{P}\left(\text { Observe }_{\mathrm{it}}=1\right)\right)+\Sigma \log \left(\mathrm{P}\left(\text { Observe }_{\mathrm{it}}=0\right)\right)
$$

This model can be estimated using the maximum-likelihood method.

An important assumption of the bivariate probit model is that $X_{F, i t}$ and $X_{D, i t}$ do not contain the same set of variables such that at least one vector has one or more variables absent in the other vector. This condition is satisfied in our study because some variables affect fraud incidence directly without appreciably affecting the likelihood of detection, yielding variables in $X_{F, i t}$ that are not present in $X_{D, i t}$. Prior studies indicate that the groups responsible for detecting most securities fraud (such as the SEC, employees, and the media; see Dyck et al., 2010) rarely use most of the variables influencing fraud commitment in their detection efforts (Cox, Kiku, and Thomas, 2003; Bowen, Call, and Rajgopal, 2010).

To account for possible correlations among firms in the same industry, robust standard errors are clustered at the industry level (the Fama-French (1997) 48 industry groupings.) We also cluster standard errors at the firm and the CEO-firm level. The results, reported in the Appendix 1, Panel D, are robust.

\section{II.2. Variables}

\section{II.2.1. Fraud}

Our primary source of fraud data is the Federal Securities Regulation (FSR) database described in Karpoff et al. (2012), who carefully study Securities and Exchange Commission (SEC) and Department of Justice (DOJ) publications and compile an exhaustive list of Federal enforcement actions under Section 13(b). Because sometimes there are multiple enforcement actions for a single instance of an alleged 
Section 13(b) violation, they group these actions together so that only one case is identified. For each case, FSR provides detailed relevant information.

The SEC also brings other enforcement actions that go beyond the section 13(b) violations covered by FSR. Thus, we supplement FSR with alleged fraud cases from the SEC's online Litigation Releases (http://www.sec.gov/litigation.shtml), which contain information on civil lawsuits and administrative proceedings brought by the SEC for alleged financial misreporting, insider trading, violations of the Foreign Corruption Practice Act, violations of the Sarbanes-Oxley Act, and other alleged violations of the Federal Securities Laws and accompanying regulations.

Shareholders may also bring private civil suits, independently of the SEC, for infractions beyond those covered in FSR. Thus, we supplement FSR and SEC with data from the Stanford Securities Class Action Clearinghouse (SSCAC) (http://securities.stanford.edu/index.html), which provides information on private securities fraud class actions. It provides a collection of likely discovered fraud cases, including virtually all alleged frauds with more than a de minimis effect on stock price that could generate private litigation. ${ }^{10}$ However, such private suits might include frivolous suits, because private litigants may be using the costs of the legal system as means to extract a monetary settlement (Alexander, 1991; Grundfest, 1995; Choi, 2007; Choi et al., 2009; Dyck et al., 2010). This raises a concern about false detections, which motivated Dyck et al. (2010) to apply careful screening procedures to exclude suits that could potentially be mistaken or frivolous. In particular, they exclude (i) cases that were subsequently dismissed by a court and (ii) settled cases where the settlement amounts are less than $\$ 3$ million. ${ }^{11}$ These screens are the standard treatment in the securities fraud literature when addressing the concern of overinclusion and we also rely on them to screen cases from SSCAC. However, unlike Dyck et al., we do not exclude backdating cases, IPO underwriter allocation cases, mutual fund timing and late trading cases,

\footnotetext{
${ }^{10}$ Filing a securities class action lawsuit is now a largely automated process whereby law firms file a suit whenever there is a negative stock price movement above a certain de minimis level (Choi, Nelson, and Pritchard, 2009).

${ }^{11}$ The threshold of \$3 million originates from previous studies (Grundfest, 1995; Choi, 2007; and Choi et al., 2009), which suggest a settlement amount as an indicator to separate frivolous suits from meritorious ones. They find suits settling below a $\$ 2.5$ - \$1.5 million threshold are on average frivolous. The range reflects the cost to the law firm for its effort in filing. A firm settling for less than $\$ 1.5$ million is almost certainly just paying lawyer fees to avoid negative court exposure.
} 
analyst cases involving false provision of favorable coverage, or cases where defendants claim they are settling to avoid negative publicity if the settlement amount exceeds \$3 million.

For cases from FSR and the SEC’s website, we do not screen cases settled for amounts less than $\$ 3$ million. SEC enforcement actions are less likely to be frivolous or mistaken than private suits because the people making enforcement decisions (the SEC's employees) do not directly receive the monetary remedies (as a private litigant might). Thus, a small settlement amount in a SEC case does not imply a frivolous suit; instead, perhaps the SEC pursued a case involving a small damage because the case raised important legal or enforcement questions or perhaps the SEC demanded a substantial change in financial reporting and/or improvement in corporate governance in lieu of a large settlement. We do, however, exclude suits in FSR and SEC dismissed by the courts.

Our sample period runs from 1996 to 2009. (We started compiling data in 2010.) RiskMetrics provides board data starting in 1996. This is also the first year after the passage of the Private Securities Litigation Reform Act 1995, which was designed to reduce frivolous private securities fraud class actions. Although our sample period ends in 2009, the fraud sample includes only frauds occurring no later than 2006 to allow inclusion of frauds that took place during the sample period but were detected between 2007 and 2009. This reduces bias due to late detection. In our sample, the average duration from the commencement of fraudulent activity to the detection date is 1,073 days. For firms with multiple securities lawsuits, we use the one involving the most number of people charged in the litigation.

Because our inquiry is about the role CEO connectedness plays in fraud, we exclude cases in which the CEO is not a named respondent. Although not being named does not necessarily mean the CEO was uninvolved, CEO culpability is less likely. These screening criteria yield 315 unique fraud cases with 886 fraud firm-year observations that contain sufficient data to construct our measures of appointmentbased CEO connectedness. We also identify 62 unique fraud cases in which the CEO is unnamed. For completeness, we add the CEO-unnamed cases to our fraud sample and re-estimate all key regressions in Appendix 6. 


\section{II.2.2. Appointment-based CEO connectedness}

Our measures of CEO connectedness are the fraction of top four non-CEO executives appointed, $F T A_{i t} ;{ }^{12}$ and the fraction of directors appointed, $F D A_{i t}$, during the tenure of firm i's CEO as of year $t$. We follow ExecuComp and rank executives by the sum of salaries and bonuses. In calculating FDA, we exclude the CEO from both the numerator and denominator if he is on the board. We determine if the executive or the director is appointed during the current CEO’s tenure by comparing the appointment year with the year the current CEO took office. ${ }^{13}$ We assume the year a non-CEO executive first appears on the list of top four non-CEO executives is the year in which she secured the position. The appointment date of each board member is obtained from RiskMetrics. Although RiskMetrics data is available from 1996, information on directors' appointment dates is available only from 1998, therefore the sample period for FDA analyses starts in 1998 instead of 1996.

We also regress FTA and FDA on CEO tenure and other factors and use the residuals as abnormal FTA and FDA. The re-estimation results using the abnormal measures, reported in Appendix 2, are robust.

\section{II.2.3. Control variables}

Estimating the bivariate probit model requires two sets of control variables, one each for the fraud commission and detection equations. They may overlap, but should not be identical. In the baseline model, all variables in the detection equation are included in the commission equation, because the expected cost of committing fraud depends on the probability of detection. However, the commission equation contains additional variables, which do not appear in the detection equation. Factors affecting fraud commission may not have obvious implications for the likelihood of detection, because the parties responsible for detection are unlikely to rely on all factors. For frauds in FSR and SEC Litigation Releases, the primary

\footnotetext{
${ }^{12}$ Landier et al. (2013) use an FTA based on new hires only. We include all top executives added to the list of top four non-CEO executives because similar connections may arise through promotion within the firm and/or compensation increases. We also drop firm-year observations when ExecuComp reports less than five top executives (including CEO) to reduce noise in FTA $A_{i t}$. Kim and Lu (2011) illustrate the importance of keeping constant the number of executives when constructing executive variables. Cross-checking against proxy statements shows that missing executives in ExecuComp are due to omission: The firm-year observations with less than five top executives in ExecuComp show five or more top executives in proxy statements.

${ }^{13}$ When the appointment year of the current CEO and an executive or a director is the same, as in Morse et al. (2011), we do not include the executive or director in calculating FTA or FDA because we cannot determine who is appointed first.
} 
detector is the SEC. ${ }^{14}$ Prior studies show that the SEC does not rely on the fraud incidence variables identified by prior literature in motivating their detection efforts, but rather on financial distress (Cox et al., 2003; Bowen et al., 2010). For frauds in SSCAC the primary detectors are employees, the media and other regulatory bodies (Dyck et al., 2010). The detectors are highly unlikely to rely on all the variables we include in the commission equation. It is also possible that individuals considering engaging in wrongdoing may not fully appreciate all the factors influencing fraud detection; hence, we allow some control variables in the detection equation to be omitted from the commission equation and report the estimation results in Appendix 1, Panel A. The results are robust.

\section{- $\quad$ Fraud Detection}

Internal and external monitoring may play an important role in detecting fraud. Control variables related to internal monitoring by the board include: (1) the percentage of non-independent directors on the board, \%_NonIndepDirectors. The monitoring role played by independent directors has been widely documented; for example, Weisbach (1988) finds CEO turnover following poor performance is positively related to the fraction of outside directors. (2) Log of the number of directors on the board, Ln(BoardSize). Prior research indicates larger boards tend to be less effective monitors (Lipton and Lorsch, 1992; Jensen, 1993; Yermack, 1996; and Eisenberg, Sundren, and Wells, 1998). (3) Log of the number of board meetings in a given year, Ln(BoardMeetings), which may indicate the strength of board oversight and monitoring (Vafeas, 1999). (4) The percentage of non-independent directors on the audit committee, \%_NonIndepDirectors_Audit, and (5) the log of the number of directors on the audit committee, Ln(AuditComSize). Audit committees, charged with the oversight of financial reporting, internal controls, and external audits, play an important role in fraud detection (Deli and Gillan, 2000).

The strength of external monitoring is proxied by institutional ownership concentration (IOC) and analyst coverage (Ln(Analyst)). Previous studies document the important roles institutional investors play

\footnotetext{
${ }^{14}$ The other primary enforcer, the Department of Justice, often relies on information provided by the SEC (Garrett, 2011; Khanna, 1996)
} 
in shaping corporate governance (e.g., Hartzell and Starks, 2003; Cremers and Nair, 2005; Del Guercio, Seery, and Woidtke, 2008; Edmans, 2009; and Kim and Lu, 2011). We follow Hartzell and Starks (2003) and estimate IOC by the percentage shareholdings of the top five institutional investors. Analyst coverage is widely considered an important form of external monitoring as it reduces information asymmetry (e.g., Hong, Lim, and Stein, 2000; Brav and Lehavy, 2003; Chang, Dasgupta, and Hilary, 2006; Das, Guo, and Zhang, 2006; and Kelly and Ljungqvist, 2012). Ln(Analyst) is the logged value of one plus the number of analysts following a firm in a given year.

The securities litigation literature (e.g., Jones and Weingram, 1996; Johnson, Nelson, and Pritchard, 2007) suggests that firm performance and stock return volatility are related to a firm's litigation risk. Firm performance is proxied by Tobin's $Q$ and Ebitda/TA. Tobin's $Q$ is measured as the ratio of the market value of common equity plus the book value of total liabilities to the book value of total assets. Ebitda/TA is measured as earnings before interest, taxes, depreciation, and amortization divided by the book value of total assets. Stock return volatility, StockVolatilities, is measured as the standard deviation of daily stock returns over a given year. In addition, Wang et al. (2010) find stock turnover is positively related to fraud detection because, "High stock turnover implies that more investors are affected by the company's stock price and thus it is easier to identify a class of plaintiff investors” (p.2267). StockTurnover is the number of shares traded in a year divided by the number of shares outstanding.

Litigation intensity can be correlated among firms within an industry, and high industry litigation intensity may increase an individual firm’s litigation risk (Wang et al., 2010). Many firms in an industry may adopt similar practices that fall foul of the laws and, perhaps, enforcement authorities learn through experience how to detect fraud in particular industries. We control for abnormal industry litigation activities with IndustryLitigation, the yearly deviation from the average litigation intensity in an industry. The level of litigation intensity in an industry is measured by the number of lawsuits in the FSR, SEC, and SSCAC databases against publicly-listed firms in an industry in a given year (prior to application of 
any litigation screens) divided by the number of firms covered by Compustat in the same industry in the same year. When a fraud case is covered by more than one data source, it is counted only once.

We also control for firm size, sales growth rate, and leverage. Frauds by larger firms (Wang et al., 2010) and higher growth firms are more likely to be detected because they tend to attract more investor attention. Firms with high financial leverage may be more closely monitored by banks and fixed-income investors. We measure firm size as the log of the book value of total assets, $\operatorname{Ln}$ (TotalAssets); growth rate as the three-year annual growth rate in sales as reported in ExecuComp, SalesGrowth_3Yr; and financial leverage as the sum of short- and long-term debt divided by the book value of total assets, Leverage.

Our controls for CEO characteristics include CEO tenure, CEO_Tenure; whether the CEO chairs the board, CEO_Chair, or is a founder, CEO_Founder; CEO share ownership, CEO_OWN and CEO_OWN ${ }^{2}$; and the log of CEO age, $\ln \left(C E O \_A g e\right)$. We control for CEO tenure because FTA and FDA are related to the current CEO's tenure and a CEO with longer tenure may have more influence. CEOs chairing the board may be more powerful, making it easier to weaken the intensity of internal and external monitoring. A founder CEO may be more knowledgeable about the organization and more powerful. A CEO is considered a founder if he was the CEO five years prior to going public, where the date of going public is assumed to be the first date the firm appears in the CRSP database (Bebchuk, Cremer, and Peyer, 2011). CEO share ownership may affect the incidence of frauds by influencing firm performance and risk taking. We include CEO_OWN ${ }^{2}$ because Kim and Lu (2011) show CEO_OWN is related to firm performance and risk-taking in a hump shaped fashion. CEO age is added because older CEOs tend to be more experienced and cautious.

\section{- $\quad$ Fraud Incidence}

The likelihood of fraud occurring is influenced by (1) variables that affect detection because the likelihood of detection affects the expected costs of committing fraud, and (2) variables that have their own direct influence on the incentives to engage in fraud regardless of whether they also affect detection. For example, Tobin's $Q$ and Ebitda/TA, which are included in the detection equation, may also be directly 
related to fraud incidence, as fraud is more likely when a firm is suffering operating troubles (Arlen and Carney 1992; Alexander and Cohen, 1999). Higher leverage may increase fraud incidence by providing the incentive for firms to inflate reported earnings and other accounting measures to avoid violating debt covenants. Career concerns may discourage younger CEOs from committing frauds. Founder CEOs are more venturesome, a characteristic that may be extended to activities of uncertain legality.

Besides these factors, other variables may directly affect the likelihood of committing frauds without an obvious influence on detection. Wang et al. (2010) argue the incidence of fraud is related to investor beliefs about industry prospects and provide evidence of a hump-shaped relation with industry Tobin’s Q. Product market competition may also affect fraud incidence by reducing managerial slack and strengthening governance (Guadalupe and Wulf, 2010; Giroud and Mueller, 2010, 2011; Kim and Lu, 2011). Competition is measured by industry concentration ratio (ICR), which is the sum of the market share of the four biggest firms in sales among all firms in Compustat in the same industry in a given year. ${ }^{15}$ A lower ratio indicates greater competition.

We include Industry $Q$, (Industry $Q)^{2}$, and ICR in the fraud commission equation, but following Wang et al. (2010), Industry $Q$ and (Industry $Q)^{2}$ are excluded from the detection equation. We also exclude ICR from the detection equation. ${ }^{16}$ There is little reason to believe these factors affect the likelihood of detection because the likely enforcers, such as the SEC, do not seem to rely on these factors in their detection efforts (Cox et al., 2003; Bowen at al., 2010). Table I describes all key variables.

\section{II.3. Sample Construction}

CEO and executive data are taken from ExecuComp; board information, from RiskMetrics; firm characteristics and accounting data, from Compustat; stock return and trading data, from CRSP; analyst

\footnotetext{
${ }^{15}$ The Economic Census uses the largest 4, 8, 20, or 50 companies to compute ICRs. Because Compustat covers only public firms, we rely on the four largest companies to minimize the possibility of excluding private firms.

${ }^{16}$ Wang and Winton (2012) argue industry competition is related to the amount of information collection about individual firms, which may affect fraud detection. We re-estimate the bivariate probit model while including the ICR in both the detection and the commission equations. The results, reported in Appendix 1, Panel B, are robust. We do not include ICR in the detection regression because the detection equation already contains a number of variables correlated with the amount of information about individual firms - the number of financial analysts, stock turnover, institutional investor concentration, and stock volatility.
} 
coverage data, from I/B/E/S from Thomson Reuters; and institutional ownership data, from the CDA Spectrum database. Merging these databases with fraud data provides a large panel dataset from 1996 through 2006.

Table II reports the sample distribution of all firms with data available to construct FTA or FDA and of firms with identified fraud. Panel A shows the sample distribution by year. The total number of sample firms is relatively stable over time, while the number of firms with frauds varies considerably. In the first few observation years, fraud firms are small both in number and percentage, but they increase as the year progresses. The peak is 2001, a year with an unusually large number of business scandals. The year of fraud is defined as the year when fraud took place, not the year of detection. When a fraud lasts more than one year, we have multiple firm-year observations associated with that fraud.

Panel B shows the sample distribution by FTA, FDA, and their abnormal measures. FTA has five values because we consider only top-four non-CEO executives, so we separate FTA and FDA into five groups by 0.25 increments, and AFTA and AFDA into quintiles. Column (4) shows the percentage of firms engaged in wrongdoing decreases initially in FTA but increases from FTA $=0.25$. This bi-modal pattern is accentuated in its abnormal measure, AFTA, which is separated into quintiles, with the percentage of firms with alleged fraud sharply increasing from the middle quintile. FDA shows a similar pattern as FTA, but AFDA does not. The number of observations is smaller for FDA than FTA, because director appointment date is available only from 1998. FTA calculation starts in 1996.

\section{II.4. Summary Statistics}

Table III contains summary statistics for all key variables. The statistics for the full sample are reported in Panel A. The mean Fraud is 0.05 , indicating fraud observations account for 5\% of all firmyear observations. On average it takes 1073 days (about 3 years) from the commencement of fraudulent activity to the fraud detection date. Most frauds in our sample involve accounting related matters (93\%), while $34 \%$ and $42 \%$ of frauds involve real business activities and executives taking advantage of their positions, respectively. The sum exceeds $100 \%$ because a fraud may belong to multiple categories. The 
mean and median FTA is 0.41 and 0.5 , suggesting that at a typical firm-year, about half of the top four non-CEO executives are appointees of the current CEO. The mean and median FDA is 0.37 and 0.33 , indicating that at a typical firm-year, about one-third of directors on the board are appointed during the current CEO's tenure. AFTA and AFDA, the regression residuals, are close to zero.

Panel B reports the mean of each variable separately for the fraud and non-fraud sample in Columns (6) and (7). Columns (8) and (9) show the difference in the means and the P-value of the t-test for the difference. The fraud sample shows significantly higher values for most measures of appointmentbased CEO connectedness than the non-fraud sample. (Including alternative proxies used for robustness tests, there are 14 different appointment-based CEO connectedness measures.) Control variables show, on average, fraud firms are larger and more volatile; have higher Q, lower Ebitda margins, higher leverage, higher sales growth rates, greater stock turnovers, more frequent board meetings, larger audit committees, more financial analysts, and smaller institutional ownership concentration; belong to industries with higher Q and more litigation. Fraud firms also show more founder CEOs, CEOs chairing the board, younger CEOs, and CEOs with longer tenure.

Table IV presents pair-wise correlations between the fraud indicator and FTA and FDA, separately for fraud cases in which the CEO is named (Panel A) and unnamed (Panel B). Both CEO connection measures are significantly and positively correlated to fraud incidence in CEO-named cases, but show no correlation to fraud in CEO-unnamed cases. The table also reports cross-sectional correlations of FTA and FDA with the number of days it took to detect a fraud and the number of people charged. The difference between CEO-named and CEO-unnamed cases is striking. When the CEO is named, all correlations are positive and significant in five out of six. By contrast, when the CEO is unnamed, none of the correlations is positive and significant. This difference suggests that appointmentbased CEO connectedness facilitates fraud only when the CEO is considered culpable. 


\section{FRAUD COMMISSION AND THE LIKELIHOOD OF DETECTION}

\section{III.1. Main Results}

Table $\mathrm{V}$ reports the bivariate probit estimation results. The first two columns rely on FTA as the measure of CEO connectedness; the next two columns, FDA; and the last two columns, an equally weighted combined measure of FTA and FDA, FTA+FDA, which measures CEO connectedness in both executive suites and the board room. FTA and FDA may overlap because an executive appointed during a CEO's tenure may also be appointed to the board before the CEO's tenure ends. In our sample, $16 \%$ of top four non-CEO executives appointed during the CEO tenure serve on the board. Such overlaps increase the CEO's overall connectedness. Odd numbered columns show the estimation results for the commission equation; even numbered columns show the detection equation.

The coefficients on the variables of main interest, FTA, FDA, and FTA+FDA, show the predicted signs and are statistically significant. CEO connectedness with top executives and directors is associated with greater fraud incidence and a lower likelihood of detection. The estimated coefficients of FTA suggest that a firm with all top four executives appointed during the CEO’s tenure (FTA $=1$ ) has 29.65\% higher fraud probability and $27.68 \%$ lower likelihood of detection than a firm with no top four executives appointed during the CEO tenure $(\mathrm{FTA}=0)$. A firm with all directors appointed during the CEO's tenure $(\mathrm{FDA}=1)$ has $36.11 \%$ higher fraud probability and 34.09\% lower likelihood of detection than a firm with none of the directors appointed during the CEO's tenure $(\mathrm{FDA}=0)$.

Several control variables show significant coefficients. Tobin’s Q, stock turnover, and board size are related to fewer fraud incidences and a higher likelihood of detection. Higher growth opportunities, the ease of identifying a plaintiff class of investors, and larger boards seem to have preventive effects on wrongdoing. Larger firms are associated with a significantly higher likelihood of detection, reflecting the greater scrutiny they face. Firms with faster sales growth rates during the past three years show a significantly higher likelihood of committing frauds. Some of the past high sales growth rates could be the result of misleading sales figures. Surprisingly, less independent boards (\%_NonIndepDirectors) are 
associated with a lower incidence of fraud and a higher likelihood of detection. Prior studies show no correlation between board independence and the likelihood of accounting fraud (Beasley, 1996; Agrawal and Chadha, 2005).

The three variables excluded from the detection equation show insignificant coefficients. However, the signs of coefficients on Industry $Q$ and (Industry Q) ${ }^{2}$ in Columns (1) and (3) are consistent with Wang et al. (2010), who show the incidence of fraud is related to industry Q in a hump-shaped fashion. The coefficients on the three variables are insignificant because of their high correlations. Industry $\mathrm{Q}$ is not only highly correlated with (Industry $\mathrm{Q})^{2}$, but is also significantly correlated to ICR (correlation $=-0.1507$, significant at $1 \%$ level). An F-test on the joint significance of Industry $Q$ and $(\text { Industry } Q)^{2}\left(\right.$ F-stats $=6.84$ and Prob $\left.>\mathrm{Chi}^{2}=0.0327\right)$ indicates they are jointly significant. The joint test for Industry Q, (Industry $Q)^{2}$, and ICR, yields F-stat $=8.09$ and Prob $>\mathrm{Chi}^{2}=0.0442$.

Coefficients on variables related to CEO power, CEO-chair, CEO share ownership, CEO tenure, and founder-CEOs, are mostly insignificant. It appears CEO power per se has rather insignificant effects on wrongdoing or its detection. We investigate this issue further in Section VII.2.

\section{III.2. Instrumental Variables Regressions}

Because FTA and FDA are endogenous, their relations with fraud incidence or detection may not be causal. To infer causality, we construct instrumental variables (IVs) related to FTA and FDA that are unlikely to be directly related to wrongdoing. Our IVs are CEO, top four non-CEO executive, director turnovers due to death, and an indicator for headquarters located in a remote area. CEO_Death is an indicator equal to one if the previous CEO leaves the position due to death and zero otherwise. It is defined over the current CEO's entire tenure. Exe_Death and Dir_Death are the number of top four nonCEO executives and directors who left their positions due to death during the current CEO’s tenure up to the current year, so they are defined year by year. These deaths automatically change FTA and FDA. To check whether the deaths are related to fraud, we search media articles from Factiva on the cause of deaths. None can be attributed to suicide. Table III shows, on average, the majority of non-CEO top 
executives (59\%) and directors (63\%) are previous CEOs' appointees, whose turnovers, by definition, should lead to higher FTA and FDA.

Remoteness is equal to one if the population of the county of the firm's headquarters is less than 100,000, and zero otherwise. County information of headquarters is obtained from Compustat, and the population information from the U.S. Census Bureau. Top executives tend to prefer larger metropolitan areas (e.g., New York) to remote places, so turnover rates of executives in remote headquarters are likely to be higher, leading to more appointments during the current CEO’s tenure - higher FTA. Remoteness may also lead to closer social interactions between the CEO and top executives, inducing CEOs to have more of their own appointees with whom they feel comfortable. But remoteness is unlikely to be directly related to fraud. It also is defined year by year.

The first-stage estimation results are reported in Table VI. Columns (1) and (5) correspond to the fraud commission regressions and, hence, include the IV variables and all control variables used in the fraud commission regressions in Table V. Columns (2) and (6) correspond to the fraud detection regressions, including the IV variables and all control variables used in detection regressions. When we estimate the bivariate model in the second stage, the error terms of the fraud commission and detection regressions are allowed to be correlated. As expected, FTA decreases with CEO death and increases with both executive death and remoteness. All these relations are significant. FDA is significantly and negatively related to CEO death. However, FDA's relations to director death and remoteness are positive but insignificant. The insignificant relations are probably due to the fact that a director vacancy does not have to be filled during the same or even later years and that unlike top executives, outside directors often do not live near corporate headquarters. F-statistics (IVs), representing an F-test that all the instrumental variables are jointly zero, are all well above 10 .

The second-stage estimates show predicted values of FTA and FDA, FTA_Hat and FDA_Hat, are positively related to the incidence of fraud and negatively related to detection given fraud. All coefficients of the predicted values are significant. 


\section{EXPECTED COSTS OF COMMITTING FRAUD}

We assume individuals weigh the expected cost of fraud against the expected benefit in deciding whether or not to commit fraud. Thus, if CEO connectedness reduces the cost, it will increase the incidence of fraud. In this section we investigate three possible channels through which CEO connectedness reduces the cost of committing frauds. Because the expected cost depends on penalties for wrongdoing and the likelihood of detection, we examine how CEO connectedness affects the likelihood of the CEO losing his job when tainted with fraud, an important penalty, and how CEO connectedness helps delay or evade detection. We also examine how CEO connectedness is related to the coordination costs required for fraudulent activities. We focus on the cost side, as we do not have testable predictions on how CEO connectedness affects the benefits of engaging in fraud.

\section{IV.1. Forced CEO Turnover-Fraud Sensitivity}

When CEOs' involvement in wrongdoing is detected, they may receive court determined penalties, such as civil and criminal penalties (e.g., jail, monetary sanctions); and market determined penalties, such as reputational loss and dismissals (Khanna, 1996). Unlike court determined fines or jail terms, dismissal of a CEO is largely a firm level decision. The authority to dismiss a CEO belongs to the board and, hence, closer connectedness with board members may help a CEO tainted by fraud retain his job. The board does not make the decision in isolation, however. It also considers the opinions of other top executives and their possible reactions. If, for example, other top executives oppose the dismissal, are likely to leave the firm with the CEO, and are highly valued by the board, then the board may be less inclined to dismiss the CEO. In this section we relate both FTA and FDA to the likelihood of forced CEO turnover given the detection of fraud.

Forced CEO turnover is identified following the procedure in Parrino (1997) and Jenter and Kanaan (2011). If a CEO’s departure is reported by the press as fired, forced out, or retired/resigned due to policy differences or pressure, it is classified as forced. All other departures for CEOs who are 60 years of age or older are classified as voluntary, unless they resign due to litigation or fraud. All departures for CEOs under 
60 years of age are evaluated further and are classified as forced if the article does not report the reason as death, poor health, or acceptance of another position (including the chairmanship of the board); or if the article reports that the CEO is retiring, but does not announce the retirement at least six months before the succeeding CEO takes office. Finally, cases classified as forced are reclassified as voluntary if press reports convincingly explain the departure is due to previously undisclosed personal or business reasons that are unrelated to the firm's activities.

The dependent variable is Forced_CEO_Turnover it, an indicator for forced CEO turnover. We use two alternative estimation methods: the OLS with firm- and year-fixed effects in the first three columns in Table VII and the firm level conditional logit model controlling for year dummies in the last three columns. Robust standard errors are clustered at the firm level. The variable relating a detected fraud to forced CEO turnover in year $t$ is Fraud_t-3-t, which is equal to one if fraud takes place anytime during the four-year period over year t-3 to year t. We construct this variable based on the commission date rather than the detection date, because by the time a fraud is detected the CEO involved in the fraud may already be replaced by a new CEO unassociated with the fraud. The four-year period allows time for the fraud to be detected and for the firm to decide on the fate of the CEO. The variable of main interest is the interaction of Fraud_t-3-t with FTA or FDA. The interaction term measures how CEO connectedness affects the likelihood of dismissing a CEO named in a fraud.

One key control variable is CEO_Jail\&Bar, which equals one if a CEO goes to jail and/or is barred from serving as CEO of public companies. A barred CEO cannot serve as CEO of a public company and a jailed CEO of a public company would, in all likelihood, not retain his position regardless of connectedness. Other control variables include firm performance measures such as Q, Ebitda/TA, and SalesGrowth_3Yr; firm size, Ln(TotalAssets); external monitoring, IOC and Ln(analysts); product market competition, ICR; CEO characteristics, CEO_Founder, CEO_Chair, CEO tenure, and Ln(CEO_Age); board charateristics, \%_NonIndepDirectors, Ln(BoardMeeting), and Ln(BoardSize); and industry litigation intensity, IndustryLitigation. We control for these variables because a CEO tainted by fraud is less likely to 
be dismissed if the firm performs better, is subject to less external monitoring, has a more powerful CEO, and operates in an industry less tainted by litigation. We also control for firm size, board characteristics, and industry competition, because they also may influence the dismissal decision.

The estimation results are reported in Table VII. As expected, the conditional logit estimation shows CEO_Jail\&Bar is significantly and positively related to the likelihood of forced CEO turnover. More important, the interaction of Fraud_t-3-t with FTA, FDA, or FTA+FDA shows significantly negative coefficients under both specifications. The estimated coefficients in Column (4) indicate that the probability of forced CEO turnover following a fraud is $33.85 \%$ lower for a firm with all top four executives appointed during the CEO's tenure $($ FTA $=1$ ) than for a firm with none of the top four executives appointed during the CEO's tenure (FTA = 0.) Column (5) shows the probability of forced CEO turnover is $47.54 \%$ lower when a firm has FDA $=1$ than when FDA $=0$. Control variables with significant estimated coefficients show signs that are mostly consistent with our expectations. ${ }^{17}$

\section{IV.2. Fraud Detection Duration}

CEO connectedness may also reduce the expected costs of wrongdoing by reducing the likelihood of detection. Top executives are often in a position to receive internal information about wrongdoing and do something to interdict it (Dyck et al., 2010; Bowen et al., 2010). If the executives owe their current positions to the CEO, they might be less enthusiastic about revealing information about wrongdoing or may actively help to cover it up. Connected board members may also be less eager to take actions required for detection even when they sense something is wrong. Favors can go the other way as well. When a connected executive or director commits wrongdoing, the CEO may be more forgiving and "look the other way.”

If connectedness hinders fraud detection, the more connected a CEO, the longer it would take to detect a fraud and the lower would be the probability of detection. Thus, we relate CEO connectedness to

\footnotetext{
${ }^{17}$ The control variables indicate that CEOs are subject to greater likelihood of dismissal when they are less connected to top executives and directors; institutional ownership concentration is greater; the industry is under greater litigation risk; and the CEO is older, a founder, and has a shorter tenure.
} 
fraud detection duration, the log of the number of days from the commencement of fraudulent activity to its detection date. The estimation is based on cross-sectional data for each fraud case. Independent variables are the average FTA, FDA, FTA+FDA, and control variables over each fraud period, defined as the beginning to the ending date of fraudulent activities.

Control variables include the total value of settlement, Tot_Settlement, because of its possible correlation with fraud duration. The private attorneys who bring class action suits prefer fraud with longer duration because it is likely to increase the settlement amount, in turn increasing their compensation. ${ }^{18}$ Longer duration increases the likely number of shareholders who might have traded during the fraud thereby increasing the number of plaintiffs. So the attorneys have the incentive to allege that a fraud continued for a long time and prefer bringing suits where there is evidence that the fraud has persisted longer. The enforcement attorneys at the SEC are not directly motivated by monetary compensation, but frauds that have persisted longer are likely to cause more damages and might be instances where the SEC considers it worthwhile to expend its scarce enforcement resources. For these reasons, we also control for variables that are likely to be related to the expected size of settlement and detection duration, such as the stock performance, stock volatility, and stock turnover. The stock performance is measured by the average annual buy-and-hold stock return over the fraud period.

Other controls include Ebitda/TA, firm size, leverage, sales growth rate, industry litigation, the number of financial analysts, CEO-chair, CEO-founder, CEO tenure, and CEO share ownership. Data requirements reduce the sample to 296 unique fraud cases from the original 315 fraud cases. To avoid reducing the sample size any further, we set Tot_Settlement to zero if it is missing and include Tot_Settlement_D, a dummy variable equal to one if Tot_Settlement is not missing. We account for possible correlations among fraud cases in the same industry by clustering robust standard errors at the industry level.

\footnotetext{
${ }^{18}$ We thank an anonymous referee for pointing this out to us.
} 
Table VIII, Panel A, shows that the number of days frauds remain undetected is positively and significantly related to all three measures of CEO connectedness. The estimated coefficients in the regression suggest that a fraud conducted by a firm with all top four executives appointed during the CEO's tenure $(\mathrm{FTA}=1$ ) will take 235 days longer to be detected than a fraud by a firm with FTA $=0$, while a firm with all director appointed during the CEO's tenure (FDA = 1) will take 331 days longer to be detected than a fraud by a firm with none of the directors appointed during the CEO's tenure (FDA = 0). In Panel B, the dependent variable is the hazard ratio for the Cox regression, the probability of detection in the next unit of time. Consistent with the OLS estimate, the hazard ratio is significantly and negatively related to all three measures of CEO connectedness.

FTA show higher levels of statistical significance than FDA for both fraud detection duration and the hazard ratio, consistent with Dyck et al. (2010), who find access to information is the key to fraud detection. Executives have more direct access to relevant information for fraud detection than outside directors, who tend to rely mostly on management for firm-specific information. The estimated coefficients also reveal that frauds are detected sooner with greater industry litigation, more financial analysts, smaller settlements, and weaker stock performance.

\section{IV.3. Coordination Costs and the Number of People Charged}

When wrongdoing requires coordinated action among multiple players, CEO connectedness may facilitate the wrongdoing. With more connected top executives and directors, the environment becomes more conducive for coordinated activities, making it easier to engage in frauds requiring more coordination (such as financial misstatements). We test this hypothesis by relating the log of the number of people charged plus one, Ln(Num_Charged +1), to FTA, FDA, FTA + FDA in Table IX. If coordination costs of wrongdoing are lower in firms with closer CEO connectedness, then it is less costly to involve more people in frauds and, hence, we might witness more people being involved with, and charged in, wrongdoing. We include all employees charged because each top-four connected executive may also have his own lower-tier connected managers and employees, and there are other executives 
appointed by the CEO who are not on the top-four list. That is, some of the non-top-four executives and midlevel managers charged can be connected to the CEO directly or indirectly though top-four non-CEO executives.

The set of control variables for this analysis differs sharply from previous regressions, as the purpose is to control for factors affecting the number of people charged. Some types of misbehavior may require more coordination than others, leading to more people being involved. For example, inflating earnings requires a number of people such as the CEO, CFO, accountants, and lawyers, to agree to the earnings figures (or at least not oppose them), compared to insider trading which the perpetrator requires no help. Thus, we include three indicators to distinguish different types of frauds: Accounting, Operating, and Executive. Accounting frauds are defined as misleading information about financial condition, expected growth, financial statements; misleading information to inflate stock price; violations of GAAP; and restating financial statements. Operating frauds include cases related to real corporate business activities. For example, a pharmaceutical company not disclosing dangerous side effects when announcing and marketing a new drug; a company violating environmental regulations; and a bank misleading customers. Executive frauds are defined as executives taking unlawful advantage of their positions to obtain a profit; for example, insider trading, related party transactions, and so on. Of course, a fraud case may belong to multiple types.

We also control for the total value of settlement, Tot_Settlement, because a large settlement tends to indicate large scale and/or scope in wrongdoing, which may require more participants. Industry dummies are included to account for the variation in the nature of frauds across industries and potential correlation among frauds in the same industry. Other controls include CEO tenure, Tobin’s Q, Ebitda/TA, sales growth, and leverage. The estimation is again based on cross-sectional data. Because this analysis includes fewer control variables than the fraud detection duration analysis, there are fewer missing variables, allowing us to use 308 unique fraud cases. As before, the CEO connectedness variables and the firm level control variables are their averages over each case’s fraud period. 
Table IX reports estimation results, which show the number of people charged is positively and significantly related to all three connectedness variables. The low coordination costs due to close CEO connectedness seem to be an important facilitator of corporate wrongdoing.

\section{Robustness}

This section provides robustness tests to alternative bi-variate probit model specifications, alternative measures of CEO connectedness, and an alternative sample construction. Re-estimation results, reported in Appendices 1 through 6, are summarized below.

\section{V.1. Alternative Bivariate Probit Specifications}

\section{V.1.1. Alternative combinations of control variables}

In our baseline model, all control variables in the detection equation are included in the commission equation. This is not the norm among studies using the bivariate probit model to study fraud, e.g., Wang et al. (2010). We relax this part of our baseline model by including in the commission equation only CEO characteristics, performance variables, firm size, leverage, IndustryQ, IndustryQ ${ }^{2}$, and ICR, while excluding variables mainly related to monitoring. The detection variables remain unchanged. The re-estimation results, reported in Appendix 1, Panel A, are robust.

In Panel B, we keep all the variables the same as in the baseline regression, except that we now include ICR in the detection equation. Wang and Winton (2012) argue industry competition is related to information about an individual firm, which, in turn could affect detection. This change in specification is unlikely to alter the results because the detection equation already includes the number of financial analysts, stock turnover, institutional investor concentration, firm size, and stock volatility, all of which reflect differences in information about individual firms. As expected, the re-estimation results are robust.

\section{V.1.2. Organizational changes}

Our results may be driven by major structural changes such as mergers, acquisitions, spin-offs, and divestitures, which can change the composition of executive suites and the board and thereby affect our measures of CEO connectedness. Mergers may also affect incentives to commit fraud; for example, a 
bad acquisition and ensuing poor performance may lead to unlawful attempts to cover up big losses. Thus, we add to the baseline model the number of mergers and acquisitions, $M A_{i t-1}$, and divestitures and spinoffs, $D S_{i t-1,}$ completed in the previous year. They reflect organizational changes due to acquisition, restructuring, spinoffs, and divestiture. The re-estimation results, reported in Appendix 1, Panel C, are robust.

\section{V.1.3. Clustering standard errors at the firm and the CEO-firm pair level}

In Table V, robust standard errors are clustered at the industry level to account for possible correlations among firms in the same industry. Because observations associated with a firm tend to be correlated, we also cluster standard errors at the firm level and at the CEO-firm pair level because CEO connectedness is a CEO-firm specific variable. Appendix 1, Panel D shows robust re-estimation results.

\section{V.2. Alternative Measures of CEO Connectedness}

We also check robustness to three alternative measures of CEO connectedness by re-estimating the baseline bivariate probit model, forced CEO turnover-fraud sensitivity, fraud detection duration, and the number of people charged. In addition, we separate directors into independent and non-independent directors and estimate the effects of CEO connectedness with each type.

\section{V.2.1. Abnormal measures of FTA and FDA}

FTA and FDA may be correlated with CEO tenure, the average tenure of non-CEO top executives and board members, whether the CEO is recruited from outside, and whether she is in her first year in office. Thus, we estimate the following regression in Appendix 2, Panel A and use the residuals as abnormal measures of FTA and FDA, AFTA and AFDA.

$$
\begin{aligned}
& \text { FTA }_{i t}=a_{0}+\mathrm{a}_{1} \text { CEO_Tenure }{ }_{i t}+\mathrm{a}_{2} C E O \_ \text {Tenure }_{i t}{ }^{2}+\mathrm{a}_{3} \text { Execsen }_{i t}+\mathrm{a}_{4} \text { Outside }_{i t}+\mathrm{a}_{5} \text { Unknown_Exe }_{i t} \\
& +\mathrm{a}_{6} F T A \_1 Y \_E x e_{i t}+\mathrm{a}_{7} F T A \_1 Y \_U n k n o w n \_E x e_{i t}+\text { Year }_{t}+\varepsilon_{i t} \\
& F D A_{i t}=a_{0}+\mathrm{a}_{1} \text { CEO_Tenure }{ }_{i t}+\mathrm{a}_{2} \text { CEO_Tenure }{ }_{i t}{ }^{2}+\mathrm{a}_{3} \text { Dircsen }_{i t}+\mathrm{a}_{4} \text { Outside }_{i t}+\mathrm{a}_{5} F T A \_1 Y_{-} \text {Dir }_{i t}+\text { Year }_{t} \\
& +\varepsilon_{i t}
\end{aligned}
$$

CEO_Tenure $e_{i t}$ is the number of years firm i`s CEO has been in office by year $t$. We include CEO_Tenure ${ }_{i t}{ }^{2}$ to allow for a non-linear relation between CEO tenure and the connected variables because 
the maximum of FTA and FDA is one. ${ }^{19}$ Execsen $_{i t}$ and Dircsen $_{i t}$ are the average number of years firm $i$ 's top four non-CEO executives and directors have held their positions, respectively, by year $t$. Outside $e_{i t}$ is an indicator equal to one if a CEO is from outside the firm. Unknown_Exe $e_{i t}$ is the fraction of executives whose first year on the list of the top four non-CEO executives cannot be identified based on data provided by ExecuComp. ${ }^{20}$ This variable is designed to control for noise in $F T A_{i t}$ and Execsen $_{i t}$ due to ambiguity about the precise year in which some of the top executives were appointed. FTA_1Y_Exe ${ }_{i t}$ (FDA_1Y_Dir $\left.{ }_{i t}\right)$ is the fraction of top executives (directors) appointed during a CEO's first year in office. (A new CEO appointment is sometimes followed by several top executive or director turnovers). FTA_1Y_Unknown_Exe ${ }_{i t}$ is the fraction of top executives for whom we cannot determine whether their appointment occurred during a CEO's first year in office. This controls for noise in FTA_1Y_Exe $e_{i t}$ The regression also controls for year-fixed effects to account for macroeconomic factors affecting appointment and retention decisions of top executives and directors.

We re-estimate Tables V, VII, VIII, IX using these measures of abnormal CEO connectedness in Appendix 2, Panels B through E. All results are robust.

\section{V.2.2. Tenure Weighted FTA and FDA Measures}

In calculating FTA and FDA we treat all top non-CEO executives and directors equally. However, their relative influence may vary with their tenure. For example, a director who has been on the board for a long time may have greater influence than a newly-recruited director. A similar argument can be made for a top executive with long tenure. Thus, we calculate tenure weighted FTA_WT and FDA_WT by weighting each top executive and director (appointed during the CEO’s tenure) by the executive’s and the

\footnotetext{
${ }^{19}$ If a CEO leaves the position and returns later, ExecuComp reports only the latest appointment date. Thus, simply comparing the CEO appointment date reported by ExecuComp with the current year may generate negative CEO tenure. We correct for this problem by backtracking the previous appointment year using the CEO and company names.

${ }^{20}$ ExecuComp provides appointment dates for CEOs, but not for other top executives (except for the CFO beginning in 2006). Hence, if an executive is already one of the top four non-CEO executives when the firm first appears in ExecuComp, we cannot determine when he first obtained the position. For such cases, we use the year the executive first appears in ExecuComp as the year of appointment to the top executive position and compare it with the year the current CEO took office to determine whether the executive was appointed during the CEO's tenure. Since this method underestimates FTA, we include Unknown as a control variable to mitigate the underestimation problem. We do not need similar unknown controls for FDA because the director appointment date is rarely missing after 1998.
} 
director's tenure. (The weight is each individual's tenure divided by the sum of all executives' or directors' tenure). We also calculate their abnormal measures, AFTA_WT and AFDA_WT, using the regression residuals based on FTA_WT and FDA_WT. Re-estimation results using these four different measures of CEO connectedness are reported in Appendix 3. The results are again robust.

\section{V.2.3. Compensation weighted FTA measures}

The top non-CEO executives' relative influence also may vary across rank; for example, a CEO’s connectedness with the second highest-paid executive may matter more than her connectedness with the fourth highest-paid executive. Thus, we weight FTA by executives' salaries and bonuses. FTA_WC is calculated the same way as FTA_WT, except the weight is based on non-CEO executives' salaries and bonuses. AFTA_WC is the regression residual based on FTA_WC. We do not compensation weight FDA or AFDA because of the lack of variation in director compensation. Re-estimation results based on FTA_WC and AFTA_WC are reported in Appendix 4, Panels A through D. The results are robust.

\section{V.2.4. Independent vs. non-independent directors}

FDA covers all board members. However, CEO connectedness with independent directors may have different ramifications on corporate frauds than with non-independent directors. Non-independent directors include top executives and others with a material relationship with the firm, such as major stockholders, former executives, family members of a CEO or a major stockholder, suppliers, clients, strategic alliance partners, and interlocked partners. These directors are likely to have a different relationship with the CEO than independent directors, who are required to have no material relationship with the firm. Thus, we separately calculate the fraction of independent directors appointed (FIDA) during the current CEO's tenure among independent directors and the fraction of non-independent directors appointed (FNIDA) during the CEO’s tenure among non-independent directors. (Because the denominator is different, FIDA and FNIDA do not sum to FDA.)

In Appendix 5 the four key regressions are re-estimated separately for FIDA and FNIDA, and their abnormal measures, AFIDA and AFNIDA. Because of the finer breakdown of FDA, a number of 
variables show weaker statistical significance. However, the overall results are consistent with those based on FDA, revealing that CEO connectedness with independent directors has more or less similar effects as connections with non-independent directors.

\section{V.3. Alternative Sample Construction - Inclusion of CEO-Unnamed Fraud Cases}

All analyses thus far are conducted on a sample of fraud cases in which the CEO is a named respondent, excluding the 62 fraud cases in which the CEO is unnamed. For the CEO-unnamed cases, neither FTA nor FDA is positively correlated to the incidence of fraud, detection duration, and the number of people charged (see Table IV). A sufficient number of CEO-unnamed cases would have allowed us to test whether CEO connectedness helps to prevent and uncover misconduct when the CEO is not involved. Unfortunately, 62 fraud cases are insufficient to conduct a meaningful analysis, especially given the nature of the bi-variate probit model and the numerous control variables. So we do what we can: we combine the CEO unnamed cases with the CEO-named cases and re-estimate the four key regressions to study the net effects. If CEO connectedness helps to prevent and uncover misconduct when the CEO is not involved, given the CEO-unnamed cases constitute $16 \%$ of the fraud sample, we expect substantially weaker results than those based on CEO-named fraud cases alone.

The re-estimation results are reported in Appendix 6. Many coefficients are smaller in magnitude with weaker statistical significance, reflecting the noise introduced by the CEO-unnamed fraud cases. However, the overall qualitative results do not change. This, together with the lack of significant correlations in CEO-unnamed cases (Table IV), seems to suggest that when CEOs are uninvolved, CEO connectedness has more or less neutral effects on misconduct.

\section{INTERACTIVE EFFECTS WITH MONITORING MECHANISMS}

An important purpose of governance mechanisms is to deter and detect frauds; thus, a natural question follows: Do standard governance or monitoring mechanisms mitigate the adverse effects of CEO connectedness? In this section we address this question by estimating the interactive effects of CEO connectedness with internal and external monitoring mechanisms. We proxy for the strength of internal 
monitoring by board and audit committee composition: the fraction of non-independent directors, \%_NonIndepDirectors, and the fraction of non-independent directors on the audit committee, \%_NonIndepDirectors_Audit. Table X, Panels A and B repeat the bivariate probit model estimation in Table $\mathrm{V}$ with interactions of FTA or FDA with \%_NonIndepDirectors and \%_NonIndepDirectors_Audit, respectively.

Panel A reports insignificant coefficients on both interactions of FTA and FDA with \%_NonIndepDirectors, though the signs are in the right direction. Board independence does not seem to significantly help guard against the adverse effects of CEO connectedness on wrongdoing. (Control variables are not reported.) Panel B shows more encouraging results: The interaction of FTA or FDA with \%_NonIndepDirectors_Audit, the inverse of audit committee independence, is significant. It appears that a more independent audit committee helps negate the adverse effects of CEO connectedness on fraud.

Panel C repeats the same exercise for external monitoring mechanisms, the strength of which is proxied by institutional ownership concentration, IOC. The interaction of FTA and IOC is insignificant, indicating external monitoring by institutional investors with concentrated ownership does not counteract CEO connectedness with top executives. However, the interaction of IOC and FDA in the detection equation shows a significant coefficient with a sign suggesting higher institutional ownership concentration exacerbates the negative effects of CEO connectedness with directors on the likelihood of detection. This is an intriguing result that does not render a ready explanation. However, institutional investors may sell stocks when they sense something fraudulent and, hence, may prefer to keep it hidden until they dispose of their holdings.

All we can safely conclude, based on these interactive effects, is that greater audit committee independence helps counteract the adverse influence of CEO connectedness on corporate wrongdoing. The other standard internal and external monitoring measures do not seem to have significant effects, underscoring the importance of CEO connectedness as a factor in assessing the risk of corporate fraud. 


\section{OTHER SOURCES OF CEO CONNECTIONS AND POWER}

\section{VII.1. Pre-existing Network Ties}

Appointment and recruitment are not the only ways CEOs can be connected with their executives and board members. They can also be connected through pre-existing network ties. In this section we examine how CEOs' pre-existing network ties with top executives and board members affect fraud. Chidambaran et al. (2012) find higher fraud probability when CEOs are more connected to board members via nonprofessional social connections, but find lower likelihood of fraud when the network ties are through past employment overlaps. We extend their analyses to account for the partial observability problem in fraud samples by estimating the bivariate probit model. We also investigate how CEO-top executive and CEO-board network tie relationships are related to the likelihood of fraud detection, forced CEO turnover-fraud sensitivity, detection duration, and the number of people charged.

Pre-existing network ties are obtained by manually matching an individual's name and age and company name in ExecuComp and RiskMetrics with those in BoardEx. BoardEx provides information for past employment, education background, and membership in social organizations (e.g., philanthropic and religious organizations, social clubs, and professional organizations). We count the number of network ties established during overlapping years through past employment, education, and membership in social organizations. We use the number of network ties for each category to capture the depth of past connections. We also sum the three types of ties to arrive at the total number of ties. To avoid reverse causality, we include only network ties formed prior to the CEO, the director, and the top executive joining the company. Similar measures of social connections have been used in previous papers (e.g., Cohen, Frazzini, and Malloy, 2008; Fracassi and Tate, 2012; Duchin and Sosyura, 2013).

Information on network ties is often missing or incomplete because BoardEx does not cover all relevant individuals. This problem is especially severe prior to 2000. To avoid reducing the sample size, we do not drop the missing observations; instead, when information on network ties is missing or incomplete, we assume there is no tie, which leads to underestimation of network ties. To offset this problem, we 
include as controls Pct_Known_Exe_Tie or Pct_Known_Dir_Tie, the percent of top executives or directors whose pre-existing network ties to their CEOs are known.

Appendix 7 examines CEO’s network ties with top executives. Four measures of network ties are considered: the number of overlapping ties through employment, Dir_Tie_Emp; ties through education, Dir_Tie_Edu; ties through membership to social organizations, Dir_Tie_Soc; and the sum of the three, Dir_Tie. The control variables are the same as in Tables V, VII, VIII, and IX. Estimation results are reported in Panels A through D without reporting control variables. All coefficients are insignificant, except for education ties in the detection equation in the bivariate model. ${ }^{21}$ It appears that the CEO's connections with top executives through network ties seem to have mostly insignificant effects on the incidence of fraud and the expected costs of wrongdoing.

We also investigate CEOs' network ties with the board by repeating the same estimations for directors. The estimation results are reported in Appendix 8. The commission equation shows estimation results consistent with those reported in Chidambaran et al. (2012): The incidence of fraud is insignificantly related to the total number of ties; significantly and negatively related to network ties through past employment; and significantly and positively related to network ties through membership to social organizations. These results are comforting because they indicate the relations between specific network ties and fraud probabilities are robust to different estimation methodologies and samples.

Nonetheless, our estimates also reveal that none of the CEO-board network ties is significantly related to the likelihood of detection given fraud. Unlike appointment-based connections, network connections do not seem to help hide wrongdoing. Also new is the significant and negative relation between fraud incidence and educational ties. The statistical relation between network ties and forced-CEOturnover-fraud sensitivity is weak; of the four interaction terms, only education ties shows a negative

\footnotetext{
${ }^{21}$ The bivariate estimation result suggests that education ties with top executives help uncover frauds. Perhaps an executive who has gone to school with the CEO knows the CEO better and the familiarity makes detection more likely.
} 
interaction coefficient significant at the $10 \%$ level. The statistical relations with fraud detection duration and the number of people charged are also mostly insignificant.

Overall, it seems safe to conclude that as far as corporate fraud is concerned, appointment-based CEO connectedness within executive suites and the boardroom has markedly different effects from those based on social connections. As hypothesized at the outset of the paper, the loyalty factor in appointmentbased CEO connectedness seems to have much stronger effects on fraud than the familiarity bias arising from sharing common experiences.

\section{VII.2. CEO Power Index}

CEO power affects CEOs’ relationship with other corporate leaders and, hence, may also affect fraud incidence and detection. The bivariate model estimation in Table $\mathrm{V}$ and all alternative bivariate specifications in Appendix 1 show mostly insignificant coefficients on variables related to CEO power. In this section we take a closer look at the overall effects of CEO power by constructing a composite power index and re-estimate the four key regressions using the index as the main explanatory variable.

The index, CEO_Power, captures power associated with official position, title, share ownership, and longevity. It is the sum of four indicator variables: CEO_Founder, CEO_Chair, H_CEO_OWN, and L_CEO_Tenure. H_CEO_OWN equals one if the CEO owns $10 \%$ or more of outstanding shares, and zero otherwise. L_CEO_Tenure equals one if the CEO's current tenure is longer than four years (the sample median), and zero otherwise. Because the power index is the key explanatory variable, CEO_Founder, CEO_Chair, CEO_OWN, and CEO_Tenure are dropped as controls. The remaining control variables are the same as before.

The results are presented in Appendix 9, Panels A through D without reporting control variables. Consistent with earlier results based on individual sources of CEO power, Panel A shows the composite CEO power index has insignificant effects on fraud incidence or the detection likelihood. Panel B also shows insignificant coefficients on the interaction of CEO_Power and Fraud_t-3-t, indicating CEO power does not help prevent dismissal upon discovery of fraud. Panel D shows the number of people charged is 
also insignificantly related to CEO power. Only in the detection duration regression (Panel C) does CEO power have significant effects. Unlike appointment-based connectedness, the impacts of CEO power on the risk of fraud seems to quite weak, although the power helps delay its discovery.

The CEO power index reflects only the ability to exert one's own will on others, not the norms of social influence; reciprocity, liking, and social consensus, which are enhanced through appointment-based connectedness. What facilitates the acquiescence/coordination required for corporate wrongdoing seems to be social influence, not CEO power. The CEO power reflects one-way influence from the CEO to others, which is easier to resist when the intended action or inaction is against the law, i.e., wrongdoing.

\section{CONCLUSION}

The collective behavior of corporate leaders is often critical in corporate wrongdoing, and the CEO often plays the central role. Yet there is no comprehensive study exploring how CEOs and their influence within executive suites and the boardroom impact corporate wrongdoing. This paper focuses on the effects of CEOs' social influence accumulated during the CEO's tenure through top executive and director appointment decisions.

We find appointment-based CEO connectedness is positively related to the likelihood of corporate fraud and negatively related to the likelihood of detection, given fraud. The relation is economically meaningful, statistically significant, and robust to instrumental variables regressions using CEO death, the number of executives' and directors' death during the current CEO's tenure, and geographic remoteness of a firm's headquarters as IVs. The relation is also robust to alternative specifications, several alternative measures of CEO connectedness, an alternate sample construction, and clustering standard errors at different levels.

We also identify likely channels through which appointment-based CEO connectedness facilitates wrongdoing - by delaying detection, lowering the likelihood of CEO dismissal after fraud discovery, and reducing coordination costs of conducting frauds, all of which reduce the expected costs of wrongdoing. 
Furthermore, only audit committee independence helps counteract the adverse effects of CEO connectedness. Other standard internal and external monitoring mechanisms seem rather ineffective.

CEOs can also be connected to their executives and board members by sharing common network ties established through past employment, education, and membership to various social organizations. We investigate the link between these connections and fraud incidence, detection, forced CEO turnover-fraud sensitivity, and the number of people charged in fraud. The estimation results confirm some of the earlier findings by Chidambaran et al. (2012). However, CEOs’ network ties with executives or board members show mostly insignificant relations to fraud detection probability, the ability of CEOs tainted with fraud to retain their job, and the coordination cost of wrongdoing as measured by the number of people charged in frauds.

Taken together, these results imply that the fraction of top executives and board members appointed during a CEO's tenure (1) is a critical factor in assessing a firm's likelihood of engaging in wrongdoing, (2) has effects that are not mitigated by standard monitoring mechanisms, except for audit committee independence, and thus (3) is worth the close attention of investors, regulators, and governance specialists. Further, our results underscore the importance of CEO connections built through personnel decisions in assessing the quality of governance and managing risk, as the connections seem to magnify the risk of corporate fraud. 


\section{References}

Agrawal, Anup and Sahiba Chadha, 2005, Corporate governance and accounting scandals, Journal of Law and Economics 48, 371-406.

Alexander, Cindy R. and Mark A. Cohen, 1999, Why do corporations become criminals? Ownership, hidden actions, and crime as an agency cost, Journal of Corporate Finance 5, 1-34.

Alexander, Janet C., 1991, Do the merits matter? A study of settlements of securities class actions, Stanford Law Review 43, 497 - 598.

Allen, William T., Reinier H. Kraakman, and Guhan Subramanian, 2012, Commentaries and Cases on the Law of Business Organization ( $4^{\text {th }}$ edition). Aspen Publishers, Wolters Kluwer, NY.

Arlen, Jennifer H. and William J. Carney, 1992, Vicarious liability for fraud on securities markets: Theory and evidence, University of Illinois Law Review, 691 - 740.

Bar-Gill, Oren and Lucian A. Bebchuk, 2002, Misreporting corporate performance. Harvard Law and Economics Discussion Paper No. 400. Available at SSRN: http://ssrn.com/abstract=354141 or doi:10.2139/ssrn.354141.

Beasley, Mark S., 1996, An empirical analysis of the relation between the board of director composition and financial statement fraud, Accounting Review 71, 443-465.

Beatty, Randolph P., Howard Bunsis, and John R. M. Hand, 1998, The indirect economic penalties in SEC investigations of underwriters, Journal of Financial Economics 50, 151-186.

Bebchuk, Lucian, Martjin Cremers, and Urs Peyer, 2011, The CEO payslice, Journal of Financial Economics 102, 199-221.

Becker, Gary S., 1968, Crime and punishment: An economic approach, Journal of Political Economy 76, 169-217.

Bennedsen, Morten, Francisco Perez-Gonzalez, and Daniel Wolfenzon, 2006, Do CEOs matter? NYU Working Paper No. FIN-06-032. Available at SSRN: http://ssrn.com/abstract=1293659.

Bertrand, Marianne and Antoinette Schoar, 2003, Managing with style: The effect of managers on corporate policy, Quarterly Journal of Economics 118, 1169-1208.

Bhagat, Sanjai, John Bizjak, and Jeffrey L. Coles, 1998, The shareholder wealth implications of corporate lawsuits, Financial Management 27, 4 - 27.

Brav, Alon and Reuven Lehavy, 2003. An empirical analysis of analysts’ target prices: Short-term informativeness and long-term dynamics. Journal of Finance 58, 1933-1967.

Bowen, Robert, Andrew Call, and Shiva Rajgopal, 2010, Whistle-blowing: Target firm characteristics and economic consequences, Accounting Review 85, 1239-1271.

Burns, Natasha and Simi Kedia, 2006, The impact of performance-based compensation on misreporting, Journal of Financial Economics 79, 35-67. 
Cialdini, Robert B., 1984, Principles of automatic influence. In J. Jacoby \& S. Craig (Eds.), Personal Influence: Theory, research, and practice, 1-28. Lexington, MA: Heath.

Chang, Xin, Sudipto Dasgupta, and Gilles Hilary, 2006, Analyst coverage and financing decisions, Journalof Finance 61, 3009-3048.

Chidambaran, N. K., Simi Kedia, and Naqpurnanand R. Prabhala, 2012, CEO-Director connections and corporate fraud, Fordham University School of Business Research Paper. Available at: $\underline{\text { http://ssrn.com/abstract }=1681472}$

Choi, Stephen J., 2007, Do the merits matter less after the Private Securities Litigation Reform Act? Journal of Law, Economics and Organization 23, 598-626.

Choi, Stephen J., Karen K. Nelson, and Adam C. Pritchard, 2009, The screening effect of the Private Securities Litigation Reform Act, Journal of Empirical Legal Studies 6, 35-68.

Cohen, Lauren, Andrea Frazzini, and Christopher J. Malloy, 2008, The small world of investing: Board connections and mutual fund returns, Journal of Political Economy 116, 951-979.

Coles, Jeffrey L., Naveen D. Daniel, and Lalitha Naveen, 2011, Co-opted boards, Arizona State University Working Paper, available at SSRN: http://ssrn.com/abstract=1699272.

Cox, James D., Dana Kiku, and Randall S. Thomas, 2003, SEC enforcement heuristics: An empirical inquiry, Duke Law Journal 53, 737-779.

Cronqvist, Henrik, Anil K. Makhija, and Scott E. Yonker, 2012, Behavioral consistency in corporate finance: CEO personal and corporate leverage? Journal of Financial Economics 103, 20-40.

Cremers, K.J. Martijn and Vinay B. Nair, 2005, Governance mechanisms and equity prices, Journal of Finance 60, 2859-2894.

Das, Somnath, Re-Jin Guo, and Huai Zhang, 2006. Analysts’ selective coverage and subsequent performance of newly public firms, Journal of Finance 61, 1159-1185.

Del Guercio, Diane, Laura Seery, and Tracie Woidtke, 2008, Do boards pay attention when institutional investor activists “Just Vote No”? Journal of Financial Economics 90, 84-103.

Deli, Daniel N. and Stuart Gillan, 2000, On the demand for independent and active audit committees, Journal of Corporate Finance 6, 427-45.

Duchin, Ran, and Denis Sosyura, 2013, Divisional managers and internal capital markets, Journal of Finance 68, 387-430.

Dyck, I. J. Alexander, Adair Morse, and Luigi Zingales, 2010, Who blows the whistle on corporate fraud? Journal of Finance 65, 2213-2254.

Edmans, Alex, 2009, Blockholder trading, market efficiency, and managerial myopia, Journal of Finance 64, 2481-2514.

Edmans, Alex, Itay Goldstein, and John Zhu, 2013, Contracting with synergies. University of Pennsylvania Wharton School Working Paper. Available at: 
http://papers.ssrn.com/sol3/papers.cfm?abstract_id=1958708.

Efendi, Jap, Anup Srivastava, and Edward Swanson, 2007, Why do corporate managers misstate financial statements? The role of in-the-money options and other incentives, Journal of Financial Economics 85, 667-708.

Eisenberg, Theodore, Stefan Sundren, and Martin T. Wells, 1998, Larger board size and decreasing firm value in small firms, Journal of Financial Economic 48, 35-54.

Fama, Eugene F. and Kenneth R. French, 1997, Industry costs of equity, Journal of Financial Economics 43, 153-193.

Fracassi, Cesare and Geoffrey Tate, 2012, External networking and internal firm governance, Journal of Finance 67, 153-194.

Gande, Amar and Craig M. Lewis, 2009, Shareholder-initiated class action lawsuits: Shareholder wealth effects and industry spillovers. Journal of Financial and Quantitative Analysis 44, 823-850.

Garrett, Brandon L., 2011, Collaborative organizational prosecution. Prosecutors in the Boardroom: Using Criminal Law to Regulate Corporate Conduct, Rachel Barkow and Anthony Barkow (Eds.), 154-176. New York, NYU Press.

Giroud, Xavier and Holger M. Mueller, 2010, Does corporate governance matter in competitive industries? Journal of Financial Economics 95, 312-331.

Giroud, Xavier and Holger M. Mueller, 2011, Corporate governance, product market competition, and equity price, Journal of Finance 66, 563-600.

Graham, John R., Campbell R. Harvey, and Manju Puri, 2013, Managerial attitudes and corporate actions, Journal of Financial Economics, forthcoming. Available at: http://dx.doi.org/10.1016/j.hfineco.2013.01.010

Grundfest, Joseph A., 1995, Why disimplify? Harvard Law Review 108, 740-741.

Guadalupe, Maria and Julie Wulf, 2010, The flattening firm and product market competition: The effect of trade liberalization, American Economic Journal: Applied Economics 2, 105-127.

Hartzell, Jay and Laura T. Starks, 2003, Institutional investors and executive compensation, Journal of Finance 58, 2351-2374.

Hertzberg, Andrew, 2005, Managerial incentives, misreporting, and the timing of social learning: A theory of slow booms and rapid recessions, Northwestern University Working Paper.

Hong, Harrison, Terence Lim, and Jeremy C. Stein, 2000. Bad news travels slowly: Size, analyst coverage, and the profitability of momentum strategies. Journal of Finance 55, 265-295.

Jensen, Michael C., 1993, The modern industrial revolution, exit, and the failure of internal control systems, Journal of Finance 48, 831-880. 
Jenter, Dirk and Katharina Lewellen, 2011, CEO preferences and acquisitions, Stanford University Working Paper. Available at: http://ssrn.com/abstract=1969619.

Jenter, Dirk and Fadi Kanaan, 2011, CEO turnover and relative performance evaluation, Journal of Finance, forthcoming.

Johnson, Marilyn F., Karen K. Nelson, and Adam C. Pritchard, 2007, Do the merits matter more? The impact of the Private Securities Litigation Reform Act, Journal of Law, Economics, and Organization 23, 627-652.

Jones, Christopher and Seth Weingram, 1996, The determinants of 10b-5 litigation risk, Stanford Law School Working Paper.

Karpoff, Jonathan M., Allison Koester, D. Scott Lee, and Gerald S. Martin, 2012, An analysis of database challenges in financial misconduct research, Working Paper available at: http://papers.ssrn.com/sol3/papers.cfm?abstract_id=2112569.

Karpoff, Jonathan M., D. Scott Lee, and Gerald S. Martin, 2008a, The cost to firms of cooking the books, Journal of Financial and Quantitative Analysis 43, 581-612.

Karpoff, Jonathan M., D. Scott Lee, and Gerald S. Martin, 2008b, The consequences to managers for cooking the books, Journal of Financial Economics 88, 193-215.

Karpoff, Jonathan M., D. Scott Lee, and Gerald S. Martin, 2010, Bribery: Business as usual?, Available at SSRN: http://ssrn.com/abstract=1573222.

Karpoff, Jonathan M., D. Scott Lee, and Valaria P. Vendrzyk, 1999, Defense procurement fraud, penalties, and contractor influence, Journal of Political Economy 107, 809-842.

Karpoff, Jonathan M. and John R. Lott, Jr., 1993, The reputational penalty firms bear from committing criminal fraud, Journal of Law and Economics 36, 757-802.

Kelly, Bryan and Alexander Ljungqvist, 2012, Testing asymmetric-information asset pricing models. Review of Financial Studies 25, 1366-1413.

Khanna, Vikramaditya S. 1996, Corporate criminal liability: What purpose does it serve? Harvard Law Review 109, 1477 - 1534.

Khanna, Vikramaditya, 2003, Should the behavior of top management matter? Georgetown Law Journal $91,1215-1256$.

Kim, E. Han and Yao Lu, 2011, CEO ownership, external governance, and risk-taking, Journal of Financial Economics 102, 272-292.

Kim, E. Han and Yao Lu, 2013, The independent board requirement and CEO connectedness, University of Michigan Working Paper. Available at: http://ssrn.com/abstract=2119716.

Landier, Augustin, Julien Sauvagnat, David Sraer, and David Thesmar, 2013, Bottom-up corporate governance, Review of Finance 17, 161-201. 
Lipton, Martin and Jay W. Lorsch, 1992, A modest proposal for improved corporate governance, Business Lawyer 48, 59-77.

Morse, Adair, Vikram Nanda, and Amit Seru, 2011, Are incentive contracts rigged by powerful CEOs? Journal of Finance 66, 1779-1821.

Murphy, Deborah L., Ronald E. Shrieves, and Samuel L. Tibbs, 2009, Determinants of the stock price reaction to allegations of corporate misconduct: Earnings, risk, and firm size effects. Journal of Financial and Quantitative Analysis 43, 581-612.

Parrino, Robert, 1997, CEO turnover and outside succession: A cross-sectional analysis, Journal of Financial Economics, 46, p. 165-197.

Peng, Lin and Ailsa Röell, 2008, Executive pay and shareholder litigation, Review of Finance 12, 141-184.

Povel, Paul, Rajdeep Singh, and Andrew Winton, 2007, Booms, busts, and fraud, Review of Financial Studies 20, 1219-1254.

Vafeas, Nikos, 1999, Board meeting frequency and firm performance, Journal of Financial Economics 53, 113-1142.

Wang, Tracy Y., 2011, Corporate securities fraud: Insights from a new empirical framework, Journal of Law, Economics and Organization, forthcoming. Available at: http://ssrn.com/abstract=561425.

Wang, Tracy Y. and Andrew Winton, 2012, Competition and corporate fraud waves, University of Minnesota Working Paper. Available at: http://ssrn.com/abstract=2103386

Wang, Tracy Y., Andrew Winton, and Xiaoyun Yu, 2010, Corporate fraud and business conditions: Evidence from IPOs, Journal of Finance 65, 2255-2292.

Weisbach, Michael S., 1988, Outside directors and CEO turnover, Journal of Financial Economics 20, 431-460.

Yermack, David L., 1996, Higher market valuation of companies with a small board of directors, Journal of Financial Economics 40, 185-212.

Yu, Frank, and Xiaoyun Yu, 2011, Corporate lobbying and fraud detection, Journal of Financial and Quantitative Analysis, forthcoming. Available at: http://ssrn.com/abstract=954368. 


\begin{tabular}{|c|c|c|}
\hline Variables & Definitions & Sources \\
\hline \multicolumn{3}{|c|}{ Panel A: Fraud Variables } \\
\hline Fraud & Indicator equal to one if a firm-year observation shows an alleged fraud, and zero otherwise. & \multirow{10}{*}{$\begin{array}{l}\text { Federal } \\
\text { Securities } \\
\text { Regulation } \\
\text { (FSR) } \\
\text { Database, } \\
\text { Stanford } \\
\text { Securities } \\
\text { Class Action } \\
\text { Clearinghouse } \\
\text { (SSCAC), and } \\
\text { the SEC } \\
\text { Litigation } \\
\text { Releases } \\
\text { (SEC) }\end{array}$} \\
\hline Fraud_t-3-t & $\begin{array}{l}\text { Indicator equal to one if fraud takes place anytime during the period over year t-3 to year t, and zero } \\
\text { otherwise. }\end{array}$ & \\
\hline Duration & $\begin{array}{l}\text { The number of days from the commencement of fraudulent activity to the fraud detection date. For the fraud } \\
\text { cases covered by FSR database, the fraud detection date is the earliest of the following dates: (1) The date the } \\
\text { target firm first announced it has received an informal request by regulators for information related to the } \\
\text { subsequent enforcement action. (2) The date the target firm first announced it has received a notice of a formal } \\
\text { order of investigation, received a subpoena, or was named a respondent in a warrant issued by regulators } \\
\text { related to the subsequent enforcement action. (3) The date of the first regulatory proceeding filed in the related } \\
\text { enforcement action. (4) The date of the first public announcement of an activity that reveals to investors a } \\
\text { possible enforcement action in the future. This date is identified in the documents associated with regulatory } \\
\text { proceedings; related private civil class action lawsuits; information associated with informal inquires, formal } \\
\text { investigations, and Wells Notices; or information released by the firm. (5) The first date of the announcement } \\
\text { of a receipt of a Wells Notice by an intended respondent to an enforcement action or the date the firm } \\
\text { announces they have reached a settlement in an intended enforcement action. (6) The date on which the first } \\
\text { related private civil class action lawsuit was filed for the same activity described in the enforcement action by } \\
\text { regulators. For alleged fraud cases that are not in the FSR database but were found in either the SEC or } \\
\text { SSCAC database, the earliest date provided by the relevant databases was used unless an earlier date was } \\
\text { discovered in a media source. In the latter case the earlier media date was used. }\end{array}$ & \\
\hline Num_Charged & The number of people charged in the litigation or enforcement action. & \\
\hline Accounting & Indicator equal to one, if a fraud is identified as involving accounting matters. & \\
\hline Operating & Indicator equal to one, if a fraud is identified as involving real business activities. & \\
\hline Executive & $\begin{array}{l}\text { Indicator equal to one if a fraud is identified as involving executives taking unlawful advantage of their } \\
\text { positions for personal benefits. }\end{array}$ & \\
\hline CEO_Jail\&Bar & $\begin{array}{l}\text { Indicator equal to one if a CEO is sentenced to jail and/or barred from serving as a CEO of a publicly listed } \\
\text { firm, and zero otherwise. }\end{array}$ & \\
\hline Tot_Settlement & Value of total settlement. The unit is 10 million dollars. Missing values are replaced by zero. & \\
\hline Tot_Settlement_D & Indicator equal to one, if Tot_Settlement is not missing, and zero otherwise. & \\
\hline \multicolumn{3}{|c|}{ Panel B: CEO Connectedness Variables } \\
\hline FTA & Fraction of top four non-CEO executives appointed during the current CEO’s tenure. & \multirow{6}{*}{ ExecuComp } \\
\hline AFTA & Abnormal fraction of top four non-CEO executives appointed during the current CEO’s tenure. & \\
\hline FTA_WT & $\begin{array}{l}\text { Fraction of top four non-CEO executives appointed during the current CEO’s tenure, weighted by the } \\
\text { executives' tenure. }\end{array}$ & \\
\hline AFTA_WT & $\begin{array}{l}\text { Abnormal fraction of top four non-CEO executives appointed during the current CEO's tenure, weighted by } \\
\text { the executives' tenure. }\end{array}$ & \\
\hline FTA_WC & $\begin{array}{l}\text { Fraction of top four non-CEO executives appointed during the current CEO’s tenure, weighted by the } \\
\text { executives' salaries and bonuses. }\end{array}$ & \\
\hline AFTA_WC & $\begin{array}{l}\text { Abnormal fraction of top four non-CEO executives appointed during the current CEO’s tenure, weighted by } \\
\text { the executives' salaries and bonuses. }\end{array}$ & \\
\hline FDA & $\begin{array}{l}\text { Fraction of directors appointed during the current CEO's tenure, excluding the CEO from both the numerator } \\
\text { and denominator if the CEO is on the board. }\end{array}$ & \multirow{10}{*}{$\begin{array}{l}\text { ExecuComp, } \\
\text { RiskMetrics }\end{array}$} \\
\hline AFDA & Abnormal fraction of directors appointed during the current CEO’s tenure. & \\
\hline FDA_WT & Fraction of directors appointed during the current CEO’s tenure, weighted by the directors’ tenure. & \\
\hline AFDA_WT & Abnormal fraction of directors appointed during the current CEO’s tenure, weighted by the directors' tenure. & \\
\hline FTA+FDA & Sum of FTA and FDA divided by 2. & \\
\hline AFTA+AFDA & Sum of AFTA and AFDA divided by 2. & \\
\hline FIDA & $\begin{array}{l}\text { Fraction of independent directors appointed during the current CEO’s tenure (i.e., the number of independent } \\
\text { directors appointed during the current CEO’s tenure divided by the total number of independent directors). }\end{array}$ & \\
\hline AFIDA & Abnormal fraction of independent directors appointed during the current CEO’s tenure. & \\
\hline FNIDA & $\begin{array}{l}\text { Fraction of non-independent directors appointed during the current CEO's tenure (i.e., the number of } \\
\text { non-independent directors appointed during the current CEO’s tenure divided by the total number of } \\
\text { non-independent directors.) }\end{array}$ & \\
\hline AFNIDA & Abnormal fraction of non-independent directors appointed during the current CEO’s tenure. & \\
\hline Dir_Tie & $\begin{array}{l}\text { The total number of pre-existing network ties a CEO has with directors through past employment (either } \\
\text { working as an employee or serving on the board), educational institutions, and past membership to social and } \\
\text { professional organizations divided by the number of directors on the board. Only network ties established } \\
\text { during overlapping years are included. }\end{array}$ & \multirow{4}{*}{$\begin{array}{l}\text { ExecuComp, } \\
\text { RiskMetrics, } \\
\text { BoardEx }\end{array}$} \\
\hline Dir_Tie_Emp & $\begin{array}{l}\text { The total number of pre-existing network ties a CEO has with directors through past employment (either } \\
\text { working as an employee or serving on the board) divided by the number of directors on the board. Only } \\
\text { network ties established during overlapping years are included. }\end{array}$ & \\
\hline Dir_Tie_Edu & $\begin{array}{l}\text { The total number of pre-existing network ties a CEO has with directors through past educational institutions } \\
\text { divided by the number of directors on the board. Only network ties established during overlapping years are } \\
\text { included. }\end{array}$ & \\
\hline Dir_Tie_Soc & $\begin{array}{l}\text { The total number of pre-existing network ties a CEO has with directors through past membership to social and } \\
\text { professional organizations divided by the number of directors on the board. Only network ties established } \\
\text { during overlapping years are included. }\end{array}$ & \\
\hline
\end{tabular}


Table I. Variable Definitions and Data Sources (Continued).

\begin{tabular}{|c|c|c|}
\hline Variables & Definitions & Sources \\
\hline $\begin{array}{l}\text { Pct_Known_Dir } \\
\text { _Tie }\end{array}$ & The percent of the directors whose pre-existing network ties to their CEOs are known. & \\
\hline Exe_Tie & $\begin{array}{l}\text { The total number of pre-existing network ties a CEO has with the top four non-CEO executives through past } \\
\text { employment (either working as an employee or serving on the board), educational institutions, and past } \\
\text { membership to social and professional organizations divided by } 4 \text {. Only network ties established during } \\
\text { overlapping years are included. }\end{array}$ & \multirow{5}{*}{$\begin{array}{l}\text { ExecuComp, } \\
\text { BoardEx }\end{array}$} \\
\hline Exe_Tie_Emp & $\begin{array}{l}\text { The total number of pre-existing network ties a CEO has with the top four non-CEO executives through past } \\
\text { employment (either working as an employee or serving on the board) divided by } 4 \text {. Only network ties } \\
\text { established during overlapping years are included. }\end{array}$ & \\
\hline Exe_Tie_Edu & $\begin{array}{l}\text { The total number of pre-existing network ties a CEO has with the top four non-CEO executives through past } \\
\text { educational institutions divided by } 4 \text {. Only network ties established during overlapping years are included. }\end{array}$ & \\
\hline Exe_Tie_Soc & $\begin{array}{l}\text { The total number of pre-existing network ties a CEO has with the top four non-CEO executives through past } \\
\text { membership to social and professional organizations divided by } 4 \text {. Only network ties established during } \\
\text { overlapping years are included. }\end{array}$ & \\
\hline $\begin{array}{l}\text { Pct_Known_Exe } \\
\text { Tie }\end{array}$ & The percent of the top four non-CEO executives whose pre-existing network ties to their CEOs are known. & \\
\hline \multicolumn{3}{|c|}{ Panel C: Variables to Construct AFTA and AFDA } \\
\hline Outside & Indicator equal to one, if a CEO comes from outside the firm and zero otherwise. & \multirow{5}{*}{ ExecuComp } \\
\hline Execsen & The average tenure of the top four non-CEO executives. & \\
\hline FTA_1Y_Exe & The fraction of the top four non-CEO executives appointed during a CEO’s first year in office. & \\
\hline Unknown_Exe & $\begin{array}{l}\text { The fraction of executives whose first year on the list of the top four non-CEO executives cannot be } \\
\text { identified. }\end{array}$ & \\
\hline $\begin{array}{l}\text { FTA_1Y } \\
\text { _Unknown_Exe }\end{array}$ & $\begin{array}{l}\text { The fraction of the top four non-CEO executives whose appointment cannot be determined as occurring } \\
\text { during a CEO's first year in office. }\end{array}$ & \\
\hline Dircsen & The average number of years for which each director has been on the board. & \multirow{2}{*}{$\begin{array}{l}\text { ExecuComp, } \\
\text { RiskMetrics }\end{array}$} \\
\hline FDA_1Y_Dir & The fraction of directors appointed during a CEO’s first year in office. & \\
\hline \multicolumn{3}{|c|}{ Panel D: Firm Characteristics and Business Condition Variables } \\
\hline Tobin's Q & $\begin{array}{l}\text { The market value of common equity plus the book value of total liabilities divided by the book value of total } \\
\text { assets. }\end{array}$ & Compustat \\
\hline Ebitda/TA & Earnings before interest, taxes, depreciation, and amortization divided by the book value of total assets. & Compustat \\
\hline StockReturns & Annual buy-and-hold stock returns. & CRSP \\
\hline Leverage & Sum of short- and long-term debt divided by the book value of total assets. & Compustat \\
\hline SalesGrowth_3Yr & The 3-year least squares annual growth rate of sales in percentage. & ExecuComp \\
\hline Ln(TotalAssets) & Logged value of the book value of total assets. & Compustat \\
\hline IndustryQ & $\begin{array}{l}\text { The median Tobin's Q in an industry in a given year. Industries are defined by Fama-French (1997) industry } \\
\text { groupings. }\end{array}$ & Compustat \\
\hline ICR & $\begin{array}{l}\text { Industry concentration ratio, as measured by the sum of the percentage market share (in sales) of the four } \\
\text { biggest firms among all firms in Compustat in each industry in each year. Industries are defined by } \\
\text { Fama-French (1997) industry groupings. }\end{array}$ & Compustat \\
\hline MA & The total number of mergers and acquisitions completed by a firm in the previous year. & SDC \\
\hline DS & The total number of divestitures and spinoffs completed by a firm in the previous year. & SDC \\
\hline \multicolumn{3}{|c|}{ Panel E: Corporate Governance and Monitoring Variables } \\
\hline Ln(BoardSize) & Logged value of one plus the number of directors on the board. & Risk Metrics \\
\hline $\begin{array}{l}\text { \%_NonIndep } \\
\text { Directors }\end{array}$ & $\begin{array}{l}\text { The number of non-independent directors, as defined by IRRC, divided by the total number of directors on } \\
\text { the board. }\end{array}$ & Risk Metrics \\
\hline Ln(BoardMeetings) & Logged value of one plus the number of board meetings held during a given year. & ExecuComp \\
\hline $\begin{array}{l}\text { \%_NonIndep } \\
\text { Directors_Audit }\end{array}$ & $\begin{array}{l}\text { The number of non-independent directors as defined by IRRC on the audit committee, divided by the total } \\
\text { number of audit committee members. }\end{array}$ & Risk Metrics \\
\hline Ln(AuditComSize) & Logged value of one plus the number of audit committee members. & Risk Metrics \\
\hline Ln(Analyst) & Logged value of one plus the number of analysts following a firm in a given year. & $\mathrm{I} / \mathrm{B} / \mathrm{E} / \mathrm{S}$ \\
\hline IOC & The sum of percentage share ownership held by the top five institutional investors. & $\begin{array}{l}\text { CDA } \\
\text { Spectrum }\end{array}$ \\
\hline
\end{tabular}


Table I. Variable Definitions and Data Sources (Continued).

\begin{tabular}{|c|c|c|}
\hline Variables & Definitions & Sources \\
\hline \multicolumn{3}{|c|}{ Panel F: Litigation Risk Variables } \\
\hline StockVolatilities & Standard deviation of a firm’s daily stock returns in a given year. & CRSP \\
\hline IndustryLitigation & $\begin{array}{l}\text { The yearly deviation from the average litigation intensity in an industry. The level of litigation } \\
\text { intensity in an industry is the number of all alleged frauds against publicly-listed firms in an industry in } \\
\text { a given year, divided by the total number of firms in Compustat for the same industry and the same } \\
\text { year. Detection date is defined in the detection duration entry. Industries are defined by Fama-French } \\
\text { (1997) industry groupings. }\end{array}$ & $\begin{array}{l}\text { FSR, } \\
\text { SSCAC, } \\
\text { SEC and } \\
\text { Compustat }\end{array}$ \\
\hline StockTurnover & (Number of shares traded in a year) / (Number of shares outstanding). & CRSP \\
\hline \multicolumn{3}{|c|}{ Panel G: CEO Characteristics Variables } \\
\hline CEO_OWN & The percentage of outstanding common shares held by a CEO. & \multirow{5}{*}{ ExecuComp } \\
\hline CEO_Founder & $\begin{array}{l}\text { Indicator equal to one, if a CEO was the CEO five years prior to the first date when the firm appears in } \\
\text { CRSP or Compustat, and zero otherwise. }\end{array}$ & \\
\hline CEO_Chair & Indicator equal to one when a CEO also chairs the board, and zero otherwise. & \\
\hline Ln(CEO_Age) & Logged value of CEO age. & \\
\hline CEO_Tenure & The number of years a CEO has been CEO. & \\
\hline $\begin{array}{l}\text { Forced_CEO } \\
\text { _Turnover }\end{array}$ & $\begin{array}{l}\text { Indicator for forced CEO turnover, identified by following the procedures used in Parrino (1997) and } \\
\text { Jenter and Kanaan (2011). If a CEO departure is reported by the press as the CEO is fired, forced out, } \\
\text { or retires or resigns due to policy differences or pressure, it is classified as forced. All other departures } \\
\text { for CEOs above and including age } 60 \text { are classified as voluntary (except for the cases due to litigation } \\
\text { or other fraud). All departures for CEOs below age } 60 \text { are evaluated further and are classified as forced } \\
\text { either if the article does not report the reason as death, poor health, or the acceptance of another } \\
\text { position (including the chairmanship of the board); or if the article reports that the CEO is retiring, but } \\
\text { does not announce the retirement at least six months before the succession. Finally, cases classified as } \\
\text { forced are reclassified as voluntary if press reports convincingly explain the departure as due to } \\
\text { previously undisclosed personal or business reasons that are unrelated to the firm's activities. }\end{array}$ & $\begin{array}{l}\text { ExecuComp } \\
\text { and Factiva }\end{array}$ \\
\hline \multicolumn{3}{|c|}{ Panel H: Instrumental Variables for CEO Connectedness Variables } \\
\hline CEO_Death & $\begin{array}{l}\text { Indicator equal to one if the previous CEO leaves the CEO position due to death, and zero otherwise. It } \\
\text { is defined over the current CEO’s entire tenure. }\end{array}$ & $\begin{array}{l}\text { ExecuComp } \\
\text { and Factiva }\end{array}$ \\
\hline Exe_Death & $\begin{array}{l}\text { The number of top four non-CEO executives who left the position due to death during the current } \\
\text { CEO's tenure up to the current year. }\end{array}$ & $\begin{array}{l}\text { ExecuComp } \\
\text { and Factiva }\end{array}$ \\
\hline Dir_Death & $\begin{array}{l}\text { The number of non-CEO directors who left the director position due to death during the current CEO's } \\
\text { tenure up to the current year. }\end{array}$ & $\begin{array}{l}\text { RiskMetrics } \\
\text { and Factiva }\end{array}$ \\
\hline Remoteness & $\begin{array}{l}\text { Indicator equal to one, if the county of the firm's headquarters has a population less than 100,000, and } \\
\text { zero otherwise. This variable is defined year by year. }\end{array}$ & $\begin{array}{l}\text { Compustat, } \\
\text { U.S. Census } \\
\text { Bureau }\end{array}$ \\
\hline
\end{tabular}


Table II. Sample Distribution.

This table describes the sample firm-year observations. Panel A lists the sample distribution by year. Panel B lists the sample distribution by the fraction of executives appointed during a CEO's tenure (FTA), the fraction of directors appointed during a CEO's tenure (FDA), and their abnormal measures (AFTA and AFDA). Table I provides definitions of these variables. Column (2) shows the total number of firms with data available to calculate FTA or FDA. Columns (3) and (4) report the number and the percentage of firms alleged to have committed fraud among the sample firms. The sample covers the period 1996 through 2006.

\begin{tabular}{|c|c|c|c|}
\hline \multicolumn{4}{|l|}{ Panel A: Sample Distribution by Year } \\
\hline Year & \# of Firms & \# of Firms with Frauds & \%_Fraud \\
\hline$(1)$ & (2) & (3) & (4) \\
\hline 1996 & 1,518 & 34 & 2.240 \\
\hline 1997 & 1,551 & 56 & 3.611 \\
\hline 1998 & 1,607 & 58 & 3.609 \\
\hline 1999 & 1,684 & 94 & 5.582 \\
\hline 2000 & 1,670 & 114 & 6.826 \\
\hline 2001 & 1,562 & 118 & 7.554 \\
\hline 2002 & 1,574 & 104 & 6.607 \\
\hline 2003 & 1,630 & 87 & 5.337 \\
\hline 2004 & 1,637 & 79 & 4.826 \\
\hline 2005 & 1,628 & 75 & 4.607 \\
\hline 2006 & 1,736 & 67 & 3.859 \\
\hline Total & 17,797 & 886 & 4.978 \\
\hline \multicolumn{4}{|c|}{ Panel B: Sample Distribution by FTA, FDA, and their Abnormal Measures (AFTA and AFDA) } \\
\hline FTA/AFTA & \# of Firms & \# of Firms with Frauds & \%_Fraud \\
\hline FTA $=0.00$ & 4,988 & 225 & 4.511 \\
\hline $\mathrm{FTA}=0.25$ & 3,586 & 151 & 4.211 \\
\hline $\mathrm{FTA}=0.50$ & 4,033 & 205 & 5.083 \\
\hline FTA $=0.75$ & 3,268 & 178 & 5.447 \\
\hline $\mathrm{FTA}=1.00$ & 1,922 & 127 & 6.608 \\
\hline AFTA $\leq 20$ Percentile & 3,562 & 190 & 5.334 \\
\hline 20 Percentile $<$ AFTA $\leq 40$ Percentile & 3,557 & 167 & 4.695 \\
\hline 40 Percentile $<$ AFTA $\leq 60$ Percentile & 3,560 & 134 & 3.764 \\
\hline 60 Percentile $<$ AFTA $\leq 80$ Percentile & 3,559 & 187 & 5.254 \\
\hline 80 Percentile $<$ AFTA & 3,559 & 208 & 5.844 \\
\hline FDA/AFDA & \# of Firms & \# of Firms with Frauds & \%_Fraud \\
\hline $\mathrm{FDA}=0.00$ & 2,395 & 133 & 5.553 \\
\hline $0.00<$ FDA $\leq 0.25$ & 2,396 & 115 & 4.800 \\
\hline $0.25<$ FDA $\leq 0.50$ & 2,690 & 131 & 4.870 \\
\hline $0.50<$ FDA $\leq 0.75$ & 2,032 & 134 & 6.594 \\
\hline $0.75<$ FDA $\leq 1.00$ & 1,550 & 116 & 7.484 \\
\hline AFDA $\leq 20$ Percentile & 2,213 & 132 & 5.965 \\
\hline 20 Percentile $<$ AFDA $\leq 40$ Percentile & 2,213 & 142 & 6.417 \\
\hline 40 Percentile $<$ AFDA $\leq 60$ Percentile & 2,212 & 120 & 5.425 \\
\hline 60 Percentile $<$ AFDA $\leq 80$ Percentile & 2,213 & 119 & 5.377 \\
\hline 80 Percentile $<$ AFDA & 2,212 & 116 & 5.244 \\
\hline
\end{tabular}


Table III. Summary Statistics of Key Variables for the Full, Fraud, and Non-Fraud Samples.

This table reports summary statistics for key variables. Panel A contains the statistics for the full sample. Panel B reports the mean of each variable separately for the fraud and non-fraud sample. Columns (8) and (9) show for each variable the difference in mean between the fraud and non-fraud sample and the P-value of the difference, respectively. The definitions of all variables are provided in Table I. Coefficients marked with *, **, and *** are significant at $10 \%, 5 \%, 1 \%$, respectively.

\begin{tabular}{|c|c|c|c|c|c|c|c|c|c|}
\hline \multirow[b]{2}{*}{ Variable } & \multicolumn{5}{|c|}{ Panel A: Full Sample } & \multicolumn{4}{|c|}{ Panel B: Fraud and Non-Fraud Firm Samples } \\
\hline & Mean & Median & S.D. & Min & Max & Fraud & Non-Fraud & $(8)=(6)-(7)$ & P-value \\
\hline & (1) & (2) & (3) & (4) & (5) & (6) & (7) & (8) & (9) \\
\hline \multicolumn{10}{|l|}{ Fraud Variables } \\
\hline Fraud & 0.050 & 0.000 & 0.218 & 0.000 & 1.000 & & & & \\
\hline Fraud $_{-t-3-t}$ & 0.058 & 0.000 & 0.234 & 0.000 & 1.000 & & & & \\
\hline CEO_Jail\&Bar & 0.002 & 0.000 & 0.046 & 0.000 & 1.000 & & & & \\
\hline Duration_Day & 1073.051 & 794.000 & 919.153 & 25.000 & 5548.000 & & & & \\
\hline Num_Charged & 4.867 & 3.000 & 3.953 & 1.000 & 24.000 & & & & \\
\hline Tot_Settlement & 5.046 & 0.300 & 44.139 & 0.000 & 762.700 & & & & \\
\hline Tot_Settlement_D & 0.698 & 1.000 & 0.460 & 0.000 & 1.000 & & & & \\
\hline Accounting & 0.927 & 1.000 & 0.261 & 0.000 & 1.000 & & & & \\
\hline Operating & 0.343 & 0.000 & 0.475 & 0.000 & 1.000 & & & & \\
\hline Executive & 0.419 & 0.000 & 0.494 & 0.000 & 1.000 & & & & \\
\hline \multicolumn{10}{|l|}{ CEO Connectedness Variables } \\
\hline FTA & 0.409 & 0.500 & 0.336 & 0.000 & 1.000 & 0.452 & 0.407 & $0.045 * * *$ & $(0.000)$ \\
\hline AFTA & 0.000 & 0.008 & 0.292 & -0.907 & 1.096 & 0.012 & -0.001 & 0.013 & $(0.212)$ \\
\hline FTA_WT & 0.347 & 0.263 & 0.323 & 0.000 & 1.000 & 0.391 & 0.345 & $0.046 * * *$ & $(0.000)$ \\
\hline AFTA_WT & 0.000 & -0.030 & 0.285 & -0.837 & 1.009 & 0.013 & -0.001 & 0.014 & $(0.160)$ \\
\hline FTA_WC & 0.389 & 0.374 & 0.336 & 0.000 & 1.000 & 0.440 & 0.386 & $0.054 * * *$ & $(0.000)$ \\
\hline AFTA_WC & 0.000 & -0.011 & 0.292 & -0.895 & 1.076 & 0.020 & -0.001 & $0.022 * *$ & $(0.032)$ \\
\hline FDA & 0.369 & 0.333 & 0.301 & 0.000 & 1.000 & 0.410 & 0.366 & $0.043 * * *$ & $(0.000)$ \\
\hline AFDA & 0.000 & -0.006 & 0.147 & -1.095 & 0.798 & -0.009 & 0.001 & -0.009 & (0.127) \\
\hline FIDA & 0.435 & 0.400 & 0.359 & 0.000 & 1.000 & 0.474 & 0.433 & $0.041^{* * *}$ & $(0.005)$ \\
\hline AFIDA & 0.000 & -0.005 & 0.172 & -1.228 & 0.960 & -0.011 & 0.001 & $-0.012^{*}$ & (0.093) \\
\hline FDA_WT & 0.220 & 0.113 & 0.254 & 0.000 & 1.000 & 0.257 & 0.218 & $0.039 * * *$ & $(0.000)$ \\
\hline AFDA_WT & 0.000 & -0.022 & 0.145 & -0.831 & 0.783 & -0.006 & 0.000 & -0.006 & $(0.285)$ \\
\hline $\mathrm{FTA}+\mathrm{FDA}$ & 0.420 & 0.429 & 0.260 & 0.000 & 1.000 & 0.449 & 0.418 & $0.031^{* * *}$ & $(0.004)$ \\
\hline AFTA+AFDA & 0.022 & 0.025 & 0.159 & -0.700 & 0.810 & 0.016 & 0.023 & -0.007 & $(0.269)$ \\
\hline Dir_Tie & 0.541 & 0.556 & 0.425 & 0.000 & 3.333 & 0.529 & 0.541 & -0.013 & $(0.388)$ \\
\hline Dir_Tie_Emp & 0.365 & 0.308 & 0.349 & 0.000 & 3.000 & 0.346 & 0.366 & $-0.021 *$ & $(0.085)$ \\
\hline Dir_Tie_Edu & 0.090 & 0.100 & 0.071 & 0.000 & 0.833 & 0.091 & 0.090 & 0.001 & $(0.631)$ \\
\hline Dir_Tie_Soc & 0.085 & 0.091 & 0.066 & 0.000 & 0.778 & 0.092 & 0.085 & $0.007 * * *$ & $(0.002)$ \\
\hline Pct_Known_Dir_Tie & 0.709 & 1.000 & 0.421 & 0.000 & 1.000 & 0.749 & 0.707 & $0.042 * * *$ & $(0.004)$ \\
\hline Exe_Tie & 0.282 & 0.000 & 0.448 & 0.000 & 4.500 & 0.303 & 0.281 & 0.022 & $(0.158)$ \\
\hline Exe_Tie_Emp & 0.273 & 0.000 & 0.443 & 0.000 & 4.500 & 0.287 & 0.272 & 0.015 & $(0.321)$ \\
\hline Exe_Tie_Edu & 0.008 & 0.000 & 0.048 & 0.000 & 0.750 & 0.014 & 0.008 & $0.006 * * *$ & $(0.001)$ \\
\hline Exe_Tie_Soc & 0.001 & 0.000 & 0.017 & 0.000 & 0.500 & 0.002 & 0.001 & $0.001 * *$ & $(0.041)$ \\
\hline Pct_Known_Exe_Tie & 0.823 & 1.000 & 0.295 & 0.000 & 1.000 & 0.851 & 0.822 & $0.030 * * *$ & $(0.003)$ \\
\hline \multicolumn{10}{|c|}{ Firm Characteristics and Business Condition Variables } \\
\hline Tobin's Q & 2.097 & 1.503 & 2.604 & 0.298 & 105.090 & 2.657 & 2.068 & $0.589 * * *$ & $(0.000)$ \\
\hline Ebitda/TA & 0.129 & 0.127 & 0.123 & -2.948 & 0.991 & 0.111 & 0.130 & $-0.018 * * *$ & $(0.000)$ \\
\hline StockReturns & 0.068 & 0.108 & 0.483 & -3.836 & 3.303 & -0.109 & 0.077 & $-0.186 * * *$ & $(0.000)$ \\
\hline Leverage & 0.223 & 0.214 & 0.175 & 0.000 & 0.959 & 0.245 & 0.222 & $0.023^{* * *}$ & $(0.000)$ \\
\hline SalesGrowth_3Yr & 17.325 & 9.929 & 63.582 & -91.136 & 3559.292 & 31.287 & 16.596 & $14.691 * * *$ & $(0.000)$ \\
\hline Log(TotalAssets) & 0.639 & 0.461 & 1.742 & -5.419 & 7.541 & 1.310 & 0.604 & $0.706^{* * *}$ & $(0.000)$ \\
\hline IndustryQ & 1.509 & 1.344 & 0.491 & 0.842 & 3.497 & 1.594 & 1.504 & $0.090 * * *$ & $(0.000)$ \\
\hline ICR & 0.326 & 0.293 & 0.143 & 0.087 & 0.981 & 0.325 & 0.326 & -0.001 & $(0.782)$ \\
\hline MA & 0.854 & 0.000 & 1.792 & 0.000 & 72.000 & 1.317 & 0.830 & $0.487 * * *$ & $(0.000)$ \\
\hline DS & 0.259 & 0.000 & 0.826 & 0.000 & 18.000 & 0.466 & 0.248 & $0.218 * * *$ & $(0.000)$ \\
\hline \multicolumn{10}{|l|}{ CEO Characteristics Variables } \\
\hline CEO_OWN & 0.025 & 0.003 & 0.062 & 0.000 & 0.761 & 0.023 & 0.025 & -0.002 & $(0.333)$ \\
\hline CEO_Founder & 0.137 & 0.000 & 0.344 & 0.000 & 1.000 & 0.200 & 0.134 & $0.066 * * *$ & $(0.000)$ \\
\hline CEO_Chair & 0.494 & 0.000 & 0.500 & 0.000 & 1.000 & 0.538 & 0.492 & $0.046^{* * *}$ & $(0.002)$ \\
\hline Ln(CEO_Age) & 3.313 & 3.367 & 0.290 & 0.000 & 4.159 & 3.246 & 3.317 & $-0.070 * * *$ & $(0.000)$ \\
\hline CEO_Tenure & 6.703 & 4.000 & 7.142 & 0.000 & 55.000 & 7.418 & 6.666 & $0.752 * * *$ & $(0.002)$ \\
\hline Forcē_CEO_Turnover & 0.029 & 0.000 & 0.169 & 0.000 & 1.000 & 0.037 & 0.029 & 0.008 & $(0.159)$ \\
\hline Coporate Governance and Mc & oring Varia & & & & & & & & \\
\hline Ln(BoardSize) & 2.350 & 2.303 & 0.267 & 0.693 & 3.689 & 2.367 & 2.349 & 0.018 & $(0.116)$ \\
\hline \%_NonIndepDirectors & 0.336 & 0.308 & 0.174 & 0.000 & 1.000 & 0.334 & 0.336 & -0.002 & $(0.755)$ \\
\hline Ln(BoardMeetings) & 2.070 & 2.079 & 0.351 & 0.000 & 4.220 & 2.160 & 2.065 & $0.095 * * *$ & $(0.000)$ \\
\hline \%_NonIndepDirectors_Audit & 0.033 & 0.000 & 0.068 & 0.000 & 0.778 & 0.033 & 0.033 & 0.000 & $(0.978)$ \\
\hline Ln(AuditComSize) & 1.262 & 1.386 & 0.604 & 0.000 & 2.485 & 1.385 & 1.255 & $0.130 * * *$ & $(0.000)$ \\
\hline Ln(Analyst) & 1.966 & 2.197 & 1.059 & 0.000 & 3.951 & 2.216 & 1.953 & $0.263 * * *$ & $(0.000)$ \\
\hline IOC & 0.413 & 0.386 & 0.139 & 0.162 & 1.000 & 0.394 & 0.414 & $-0.020 * * *$ & $(0.000)$ \\
\hline Litigation Risk Variables & & & & & & & & & \\
\hline StockVolatilities & 0.028 & 0.024 & 0.016 & 0.000 & 0.231 & 0.033 & 0.027 & $0.006 * * *$ & $(0.000)$ \\
\hline IndustryLitigation & 0.009 & 0.004 & 0.021 & -0.022 & 0.129 & 0.015 & 0.009 & $0.006 * * *$ & $(0.000)$ \\
\hline StockTurnover & 1.842 & 1.272 & 1.852 & 0.000 & 51.324 & 2.776 & 1.793 & $0.983 * * *$ & $(0.000)$ \\
\hline Instrumental Variables for $C$ & Connectedn & ss Variable & & & & & & & \\
\hline CEO_Death & 0.005 & 0.000 & 0.071 & 0.000 & 1.000 & 0.003 & 0.005 & -0.002 & $(0.472)$ \\
\hline Exe_Death & 0.019 & 0.000 & 0.167 & 0.000 & 2.000 & 0.009 & 0.020 & $-0.011^{*}$ & $(0.056)$ \\
\hline Dir_Death & 0.015 & 0.000 & 0.124 & 0.000 & 2.000 & 0.020 & 0.015 & 0.006 & $(0.186)$ \\
\hline Remoteness & 0.029 & 0.000 & 0.169 & 0.000 & 1.000 & 0.009 & 0.030 & $-0.021 * * *$ & $(0.000)$ \\
\hline
\end{tabular}


Table IV. Pair-wise Correlations between Fraud-related Variables and CEO Connectedness Variables.

This table reports the pair-wise correlations between CEO connectedness variables and the fraud indicator, fraud detection duration in days, and the number of people charged in litigation or enforcement actions. Panel A reports the correlations for fraud cases in which the CEO is a named respondent; Panel B, fraud cases in which the CEO is unnamed. The pair-wise correlations between the fraud indicator and FTA or FDA are based on the panel data of all firm-year observations. The pair-wise correlations of FTA or FDA with detection duration and the number of people charged are based on the cross-sectional data at the fraud case level, using the average FTA or FDA over the fraud period. The definitions of all variables are provided in Table I. Coefficients marked with *, **, and *** are significant at $10 \%, 5 \%, 1 \%$, respectively.

\begin{tabular}{|c|c|c|c|}
\hline & & FTA & FDA \\
\hline \multirow{3}{*}{ Panel A: CEO-Named Cases } & Fraud & $0.029 * * *$ & $0.033 * * *$ \\
\hline & Detection Duration Days & $0.107 *$ & 0.1021 \\
\hline & Num_Charged & $0.100 *$ & $0.138 * *$ \\
\hline \multirow{3}{*}{ Panel B: CEO-Unnamed Cases } & Fraud & 0.002 & -0.013 \\
\hline & Detection Duration Days & -0.053 & 0.072 \\
\hline & Num_Charged & -0.034 & $-0.299 *$ \\
\hline
\end{tabular}


This table reports the bivariate model estimation results. Columns (1), (3), and (5) report the estimated relations between appointment-based CEO connectedness and the incidence of fraud, and Columns (2), (4), and (6) report the estimated relations between appointment-based CEO connectedness and the likelihood of detection, given fraud. The sample covers the period 1996 through 2006. Definitions of all variables are provided in Table I. All regressions include year dummies. Robust standard errors clustered at the industry level are reported in parentheses. Industries are classified by Fama-French 48 industry groupings. Coefficients marked with *, $* *$, and $* * *$ are significant at $10 \%, 5 \%, 1 \%$, respectively.

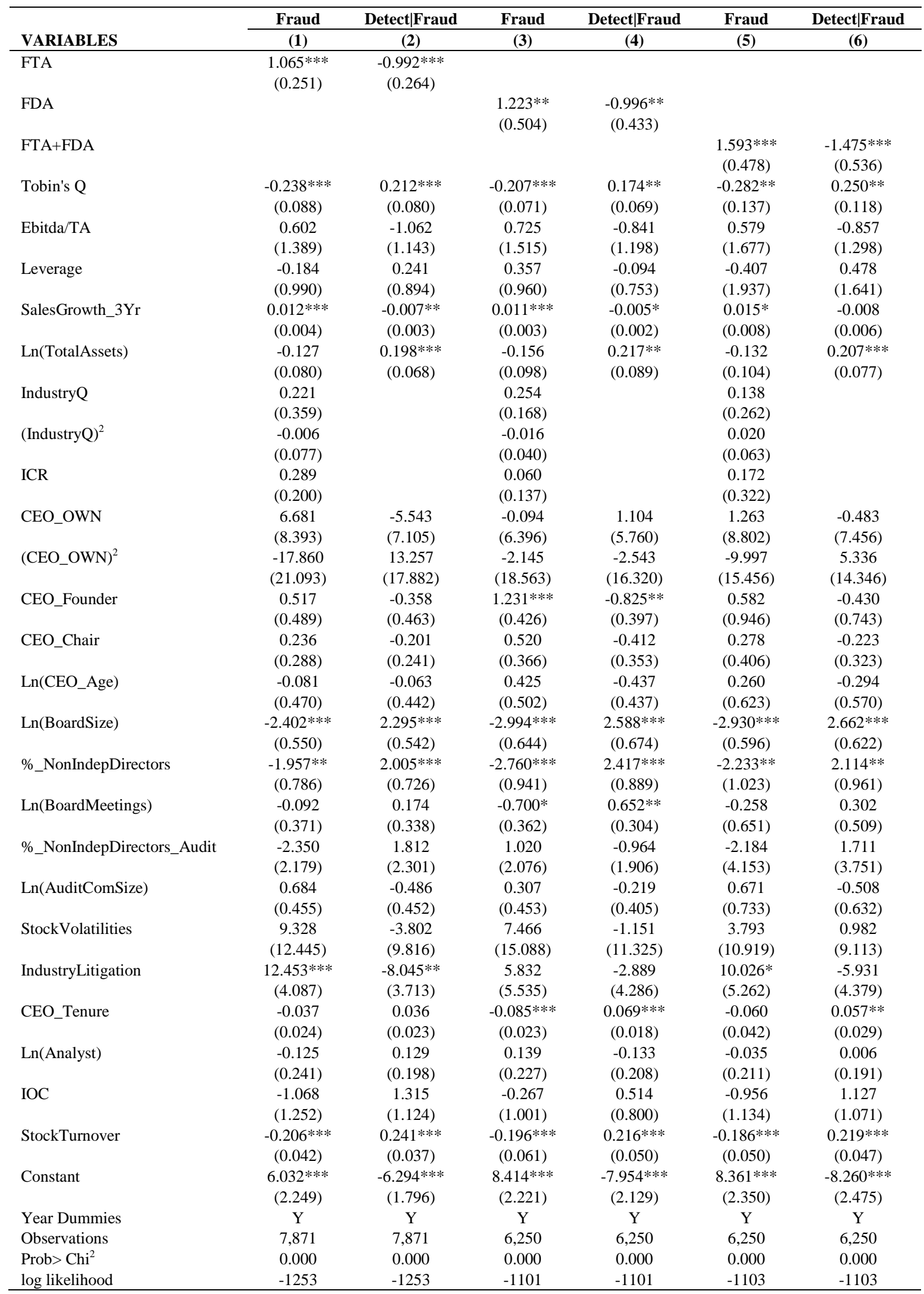


Table VI. Instrumental Variable Regressions for Corporate Fraud and Appointment-based CEO Connectedness.

This table reports the instrumental variable regression estimation results. The endogenous variables are FTA and FDA. The instrumental variables are CEO_Death, Exe_Death and Remoteness for FTA; CEO_Death, Dir_Death and Remoteness for FDA. All regressions control for year dummies. The first-stage regression estimation results are reported in Columns (1)-(2) and (5)-(6); the second-stage regression estimation results are reported in Columns (3)-(4) and (7)-(8). F-test of joint significance of instrumental variables is reported in the first stage regressions. The sample covers the period 1996 through 2006. Definitions of all variables are provided in Table I. Robust standard errors are reported in parentheses. Coefficients marked with *, **, and *** are significant at $10 \%, 5 \%$, and $1 \%$, respectively.

\begin{tabular}{|c|c|c|c|c|c|c|c|c|}
\hline \multirow[b]{3}{*}{ VARIABLES } & \multirow{2}{*}{\multicolumn{2}{|c|}{$\begin{array}{c}\text { 1st Stage } \\
\text { FTA }\end{array}$}} & \multicolumn{2}{|c|}{ 2nd Stage } & \multirow{2}{*}{\multicolumn{2}{|c|}{$\begin{array}{c}\text { 1st Stage } \\
\text { FDA }\end{array}$}} & \multicolumn{2}{|c|}{$\begin{array}{l}\text { 2nd Stage } \\
\end{array}$} \\
\hline & & & \multirow{2}{*}{$\begin{array}{c}\text { Fraud } \\
(3)\end{array}$} & \multirow{2}{*}{$\begin{array}{c}\text { Detect|Fraud } \\
(4)\end{array}$} & & & \multirow{2}{*}{$\begin{array}{c}\text { Fraud } \\
\text { (7) }\end{array}$} & \multirow{2}{*}{$\begin{array}{c}\text { Detect|Fraud } \\
(8)\end{array}$} \\
\hline & (1) & $(2)$ & & & (5) & (6) & & \\
\hline CEO_Death & $\begin{array}{l}-0.081^{*} \\
(0.048)\end{array}$ & $\begin{array}{l}-0.081^{*} \\
(0.048)\end{array}$ & & & $\begin{array}{c}-0.120^{* * *} \\
(0.035)\end{array}$ & $\begin{array}{c}-0.120^{* * *} \\
(0.035)\end{array}$ & & \\
\hline Exe_Death & $\begin{array}{c}0.057 * * * \\
(0.018)\end{array}$ & $\begin{array}{c}0.057 * * * \\
(0.018)\end{array}$ & & & & & & \\
\hline Dir_Death & & & & & $\begin{array}{c}0.015 \\
(0.018)\end{array}$ & $\begin{array}{c}0.015 \\
(0.018)\end{array}$ & & \\
\hline Remoteness & $\begin{array}{c}0.052 * * * \\
(0.018)\end{array}$ & $\begin{array}{c}0.052 * * * \\
(0.018)\end{array}$ & & & $\begin{array}{c}0.015 \\
(0.014)\end{array}$ & $\begin{array}{c}0.015 \\
(0.014)\end{array}$ & & \\
\hline FTA_Hat & & & $\begin{array}{l}11.395^{*} \\
(6.317)\end{array}$ & $\begin{array}{c}-17.288^{* *} \\
(7.115)\end{array}$ & & & & \\
\hline FDA_Hat & & & & & & & $\begin{array}{c}20.497 * * \\
(7.997)\end{array}$ & $\begin{array}{c}-14.912 * * \\
(7.021)\end{array}$ \\
\hline Tobin's Q & $\begin{array}{l}-0.000 \\
(0.002)\end{array}$ & $\begin{array}{l}-0.000 \\
(0.002)\end{array}$ & $\begin{array}{c}-0.087 * \\
(0.050)\end{array}$ & $\begin{array}{c}0.113 \\
(0.087)\end{array}$ & $\begin{array}{c}-0.003 * * \\
(0.002)\end{array}$ & $\begin{array}{c}-0.003 * * \\
(0.002)\end{array}$ & $\begin{array}{c}0.017 \\
(0.036)\end{array}$ & $\begin{array}{l}-0.017 \\
(0.033)\end{array}$ \\
\hline Ebitda/TA & $\begin{array}{l}0.075^{*} \\
(0.041)\end{array}$ & $\begin{array}{l}0.075^{*} \\
(0.041)\end{array}$ & $\begin{array}{c}-4.349 * * * \\
(1.068)\end{array}$ & $\begin{array}{c}5.377 * * * \\
(1.217)\end{array}$ & $\begin{array}{l}-0.028 \\
(0.031)\end{array}$ & $\begin{array}{l}-0.028 \\
(0.031)\end{array}$ & $\begin{array}{l}1.378^{*} \\
(0.709)\end{array}$ & $\begin{array}{c}-1.356 * * \\
(0.534)\end{array}$ \\
\hline Leverage & $\begin{array}{c}0.019 \\
(0.021)\end{array}$ & $\begin{array}{c}0.019 \\
(0.022)\end{array}$ & $\begin{array}{c}-2.020^{* * *} \\
(0.381)\end{array}$ & $\begin{array}{c}3.174 * * * \\
(0.526)\end{array}$ & $\begin{array}{l}0.042^{* *} \\
(0.016)\end{array}$ & $\begin{array}{l}0.042^{* *} \\
(0.016)\end{array}$ & $\begin{array}{c}0.183 \\
(0.443)\end{array}$ & $\begin{array}{c}0.110 \\
(0.360)\end{array}$ \\
\hline SalesGrowth_3Yr & $\begin{array}{c}-0.000 * * * \\
(0.000)\end{array}$ & $\begin{array}{c}-0.000 * * * \\
(0.000)\end{array}$ & $\begin{array}{c}0.010 * * * \\
(0.002)\end{array}$ & $\begin{array}{c}-0.008^{* * *} \\
(0.003)\end{array}$ & $\begin{array}{c}0.000 * * * \\
(0.000)\end{array}$ & $\begin{array}{c}0.000 * * * \\
(0.000)\end{array}$ & $\begin{array}{c}0.002 \\
(0.004)\end{array}$ & $\begin{array}{c}0.005 \\
(0.003)\end{array}$ \\
\hline Ln(TotalAssets) & $\begin{array}{c}0.007 * * \\
(0.003)\end{array}$ & $\begin{array}{c}0.007^{* *} \\
(0.003)\end{array}$ & $\begin{array}{l}-0.003 \\
(0.060)\end{array}$ & $\begin{array}{l}0.130^{*} \\
(0.070)\end{array}$ & $\begin{array}{c}-0.010 * * * \\
(0.003)\end{array}$ & $\begin{array}{c}-0.010 * * * \\
(0.003)\end{array}$ & $\begin{array}{c}0.064 \\
(0.074)\end{array}$ & $\begin{array}{c}0.054 \\
(0.067)\end{array}$ \\
\hline IndustryQ & $\begin{array}{c}0.001 \\
(0.004)\end{array}$ & & $\begin{array}{c}0.337^{* *} \\
(0.151)\end{array}$ & & $\begin{array}{l}-0.000 \\
(0.001)\end{array}$ & & $\begin{array}{c}0.254 \\
(0.195)\end{array}$ & \\
\hline (IndustryQ) $^{2}$ & $\begin{array}{l}-0.000 \\
(0.001)\end{array}$ & & $\begin{array}{l}-0.043 \\
(0.036)\end{array}$ & & $\begin{array}{c}0.000 \\
(0.000)\end{array}$ & & $\begin{array}{l}-0.006 \\
(0.045)\end{array}$ & \\
\hline ICR & $\begin{array}{c}0.001 \\
(0.001)\end{array}$ & & $\begin{array}{c}0.089 \\
(0.072)\end{array}$ & & $\begin{array}{l}-0.000 \\
(0.001)\end{array}$ & & $\begin{array}{c}0.028 \\
(0.124)\end{array}$ & \\
\hline CEO_OWN & $\begin{array}{c}-0.886^{* * *} \\
(0.141)\end{array}$ & $\begin{array}{c}-0.886 * * * \\
(0.142)\end{array}$ & $\begin{array}{c}16.148^{* *} \\
(7.435)\end{array}$ & $\begin{array}{c}-22.357 * * \\
(9.106)\end{array}$ & $\begin{array}{c}0.162 \\
(0.110)\end{array}$ & $\begin{array}{c}0.162 \\
(0.110)\end{array}$ & $\begin{array}{c}0.219 \\
(3.132)\end{array}$ & $\begin{array}{c}1.156 \\
(2.746)\end{array}$ \\
\hline$(\mathrm{CEO}+\mathrm{OWN})^{2}$ & $\begin{array}{c}1.092 * * * \\
(0.377)\end{array}$ & $\begin{array}{c}1.092 * * * \\
(0.379)\end{array}$ & $\begin{array}{c}-31.608 * * \\
(13.032)\end{array}$ & $\begin{array}{c}39.585 * * * \\
(15.355)\end{array}$ & $\begin{array}{c}-0.682 * * \\
(0.284)\end{array}$ & $\begin{array}{c}-0.682 * * \\
(0.284)\end{array}$ & $\begin{array}{c}-4.586 \\
(9.480)\end{array}$ & $\begin{array}{l}-1.977 \\
(8.488)\end{array}$ \\
\hline CEO_Founder & $\begin{array}{c}-0.191 * * * \\
(0.015)\end{array}$ & $\begin{array}{c}-0.191 * * * \\
(0.015)\end{array}$ & $\begin{array}{c}1.296 \\
(1.244)\end{array}$ & $\begin{array}{l}-1.533 \\
(1.459)\end{array}$ & $\begin{array}{c}-0.083^{* * *} \\
(0.012)\end{array}$ & $\begin{array}{c}-0.083 * * * \\
(0.012)\end{array}$ & $\begin{array}{c}3.272 * * * \\
(0.914)\end{array}$ & $\begin{array}{c}-2.145^{* * *} \\
(0.759)\end{array}$ \\
\hline CEO_Chair & $\begin{array}{c}0.029 * * * \\
(0.009)\end{array}$ & $\begin{array}{c}0.029 * * * \\
(0.009)\end{array}$ & $\begin{array}{c}-0.593^{*} \\
(0.355)\end{array}$ & $\begin{array}{c}0.889 * * \\
(0.436)\end{array}$ & $\begin{array}{c}0.047 * * * \\
(0.007)\end{array}$ & $\begin{array}{c}0.047 * * * \\
(0.007)\end{array}$ & $\begin{array}{l}-0.160 \\
(0.421)\end{array}$ & $\begin{array}{c}0.148 \\
(0.364)\end{array}$ \\
\hline Ln(CEO_Age) & $\begin{array}{c}-0.003 \\
(0.014)\end{array}$ & $\begin{array}{c}-0.003 \\
(0.014)\end{array}$ & $\begin{array}{c}-0.624^{* *} \\
(0.302)\end{array}$ & $\begin{array}{l}0.650^{*} \\
(0.390)\end{array}$ & $\begin{array}{c}0.011 \\
(0.011)\end{array}$ & $\begin{array}{c}0.011 \\
(0.011)\end{array}$ & $\begin{array}{l}0.522^{*} \\
(0.267)\end{array}$ & $\begin{array}{c}-0.441^{*} \\
(0.240)\end{array}$ \\
\hline Ln(BoardSize) & $\begin{array}{l}-0.005 \\
(0.017)\end{array}$ & $\begin{array}{l}-0.005 \\
(0.017)\end{array}$ & $\begin{array}{c}-1.059 * * * \\
(0.404)\end{array}$ & $\begin{array}{l}1.455^{* * *} \\
(0.559)\end{array}$ & $\begin{array}{c}0.067 * * * \\
(0.014)\end{array}$ & $\begin{array}{c}0.067 * * * \\
(0.014)\end{array}$ & $\begin{array}{c}-3.594 * * * \\
(0.547)\end{array}$ & $\begin{array}{c}2.723 * * * \\
(0.549)\end{array}$ \\
\hline \%_NonIndepDirectors & $\begin{array}{c}-0.323 * * * \\
(0.025)\end{array}$ & $\begin{array}{c}-0.323 * * * \\
(0.025)\end{array}$ & $\begin{array}{c}4.781^{* *} \\
(1.945)\end{array}$ & $\begin{array}{c}-6.930 * * * \\
(2.105)\end{array}$ & $\begin{array}{c}-0.132 * * * \\
(0.021)\end{array}$ & $\begin{array}{c}-0.132 * * * \\
(0.021)\end{array}$ & $\begin{array}{c}0.421 \\
(1.197)\end{array}$ & $\begin{array}{c}-0.243 \\
(1.063)\end{array}$ \\
\hline Ln(BoardMeetings) & $\begin{array}{c}0.041 * * * \\
(0.011)\end{array}$ & $\begin{array}{c}0.041 * * * \\
(0.011)\end{array}$ & $\begin{array}{l}-0.179 \\
(0.377)\end{array}$ & $\begin{array}{c}0.432 \\
(0.467)\end{array}$ & $\begin{array}{c}0.003 \\
(0.008)\end{array}$ & $\begin{array}{c}0.003 \\
(0.008)\end{array}$ & $\begin{array}{c}-1.035^{* * * *} \\
(0.245)\end{array}$ & $\begin{array}{c}0.804^{* * *} \\
(0.208)\end{array}$ \\
\hline \%_NonIndepDirectors_Audit & $\begin{array}{c}0.368 * * * \\
(0.060)\end{array}$ & $\begin{array}{c}0.367 * * * \\
(0.060)\end{array}$ & $\begin{array}{c}-6.166 * * * \\
(2.332)\end{array}$ & $\begin{array}{c}8.684^{* * *} \\
(2.505)\end{array}$ & $\begin{array}{c}0.131^{* * *} \\
(0.045)\end{array}$ & $\begin{array}{c}0.131^{* * *} \\
(0.045)\end{array}$ & $\begin{array}{l}-1.425 \\
(1.427)\end{array}$ & $\begin{array}{c}0.915 \\
(1.289)\end{array}$ \\
\hline Ln(AuditComSize) & $\begin{array}{c}0.025 \\
(0.017)\end{array}$ & $\begin{array}{c}0.025 \\
(0.017)\end{array}$ & $\begin{array}{c}0.244 \\
(0.286)\end{array}$ & $\begin{array}{c}-0.119 \\
(0.357)\end{array}$ & $\begin{array}{c}-0.028^{* *} \\
(0.012)\end{array}$ & $\begin{array}{c}-0.028 * * \\
(0.012)\end{array}$ & $\begin{array}{c}0.040 \\
(0.350)\end{array}$ & $\begin{array}{c}-0.005 \\
(0.289)\end{array}$ \\
\hline StockVolatilities & $\begin{array}{c}1.169 * * * \\
(0.435)\end{array}$ & $\begin{array}{c}1.171^{* * *} \\
(0.437)\end{array}$ & $\begin{array}{c}7.979 \\
(8.510)\end{array}$ & $\begin{array}{c}1.547 \\
(10.117)\end{array}$ & $\begin{array}{c}0.041 \\
(0.321)\end{array}$ & $\begin{array}{c}0.041 \\
(0.322)\end{array}$ & $\begin{array}{l}18.233^{*} \\
(10.647)\end{array}$ & $\begin{array}{c}-4.894 \\
(7.454)\end{array}$ \\
\hline IndustryLitigation & $\begin{array}{c}0.194 \\
(0.175)\end{array}$ & $\begin{array}{c}0.195 \\
(0.176)\end{array}$ & $\begin{array}{c}0.113 \\
(1.964)\end{array}$ & $\begin{array}{c}3.409 \\
(3.208)\end{array}$ & $\begin{array}{c}0.038 \\
(0.124)\end{array}$ & $\begin{array}{c}0.038 \\
(0.124)\end{array}$ & $\begin{array}{c}2.223 \\
(4.960)\end{array}$ & $\begin{array}{c}0.394 \\
(2.899)\end{array}$ \\
\hline CEO_Tenure & $\begin{array}{c}0.021 * * * \\
(0.001)\end{array}$ & $\begin{array}{c}0.021 * * * \\
(0.001)\end{array}$ & $\begin{array}{l}-0.224^{*} \\
(0.134)\end{array}$ & $\begin{array}{c}0.340 * * \\
(0.153)\end{array}$ & $\begin{array}{c}0.033 * * * \\
(0.001)\end{array}$ & $\begin{array}{c}0.033 * * * \\
(0.001)\end{array}$ & $\begin{array}{c}-0.753 * * * \\
(0.273)\end{array}$ & $\begin{array}{c}0.545^{* *} \\
(0.239)\end{array}$ \\
\hline Ln(Analyst) & $\begin{array}{l}-0.003 \\
(0.005)\end{array}$ & $\begin{array}{l}-0.003 \\
(0.005)\end{array}$ & $\begin{array}{c}0.184 \\
(0.127)\end{array}$ & $\begin{array}{l}-0.187 \\
(0.187)\end{array}$ & $\begin{array}{l}0.012^{* *} \\
(0.005)\end{array}$ & $\begin{array}{c}0.012 * * \\
(0.005)\end{array}$ & $\begin{array}{l}-0.101 \\
(0.130)\end{array}$ & $\begin{array}{c}0.071 \\
(0.113)\end{array}$ \\
\hline IOC & $\begin{array}{c}0.050 \\
(0.035)\end{array}$ & $\begin{array}{c}0.050 \\
(0.035)\end{array}$ & $\begin{array}{l}-1.387 \\
(1.080)\end{array}$ & $\begin{array}{l}2.424^{*} \\
(1.454)\end{array}$ & $\begin{array}{l}-0.023 \\
(0.027)\end{array}$ & $\begin{array}{l}-0.023 \\
(0.028)\end{array}$ & $\begin{array}{c}1.218 \\
(0.816)\end{array}$ & $\begin{array}{l}-0.540 \\
(0.669)\end{array}$ \\
\hline StockTurnover & $\begin{array}{l}-0.001 \\
(0.003)\end{array}$ & $\begin{array}{c}-0.001 \\
(0.003)\end{array}$ & $\begin{array}{c}-0.243^{* * *} \\
(0.063)\end{array}$ & $\begin{array}{c}0.265^{* * *} \\
(0.056)\end{array}$ & $\begin{array}{c}0.015^{* * *} \\
(0.002)\end{array}$ & $\begin{array}{c}0.015^{* * *} \\
(0.002)\end{array}$ & $\begin{array}{c}-0.461^{* * *} \\
(0.144)\end{array}$ & $\begin{array}{c}0.384^{* * *} \\
(0.118)\end{array}$ \\
\hline Constant & $\begin{array}{c}0.222^{* * *} \\
(0.071)\end{array}$ & $\begin{array}{c}0.223^{* * *} \\
(0.071)\end{array}$ & $\begin{array}{c}-5.559 * * * \\
(1.800)\end{array}$ & $\begin{array}{c}6.594^{* * *} \\
(2.154)\end{array}$ & $\begin{array}{c}-0.047 \\
(0.054)\end{array}$ & $\begin{array}{l}-0.047 \\
(0.054)\end{array}$ & $\begin{array}{c}7.850 * * * \\
(1.489)\end{array}$ & $\begin{array}{c}-6.838 * * * \\
(1.328)\end{array}$ \\
\hline Year Dummies & $\mathrm{Y}$ & $\mathrm{Y}$ & $\mathrm{Y}$ & $\mathrm{Y}$ & $\mathrm{Y}$ & $\mathrm{Y}$ & $\mathrm{Y}$ & $\mathrm{Y}$ \\
\hline $\begin{array}{l}\text { Observations } \\
\text { Adjusted R }{ }^{2}\end{array}$ & $\begin{array}{l}7,871 \\
0.160\end{array}$ & $\begin{array}{l}7,871 \\
0.160\end{array}$ & 7,871 & 7,871 & $\begin{array}{l}6,250 \\
0.551\end{array}$ & $\begin{array}{l}6,250 \\
0.551\end{array}$ & 6,250 & 6,250 \\
\hline Prob $>\mathrm{Chi}^{2}$ &. &. & 0.000 & 0.000 &. &. & 0.000 & 0.000 \\
\hline log likelihood & & & -1253 & -1253 & & & -1102 & -1102 \\
\hline F-statistics (IVs) & 21.36 & 21.21 & & & 13.28 & 13.26 & & \\
\hline Prob > F (IVs) & 0.0001 & 0.0001 & & & 0.0041 & 0.0041 & & \\
\hline
\end{tabular}


This table estimates the impact of appointment-based CEO connectedness on forced CEO turnover-fraud sensitivity. The dependent variable is an indicator of forced CEO turnover. The relations are estimated by the OLS in Panel A; and by the conditional logit model in Panel B. OLS regressions control for firm and year fixed effects. Conditional logit regressions control for year dummies. The sample covers the period 1996 through 2006. Definitions of all variables are provided in Table I. Robust standard errors clustered at the firm level are reported in parentheses. Coefficients marked with *, **, and *** are significant at $10 \%, 5 \%, 1 \%$, respectively.

\begin{tabular}{|c|c|c|c|c|c|c|}
\hline \multirow[b]{3}{*}{ VARIABLES } & \multicolumn{6}{|c|}{ Forced_CEO_Turnover } \\
\hline & \multicolumn{3}{|c|}{ Panel A: OLS } & \multicolumn{3}{|c|}{ Panel B: Clogit } \\
\hline & (1) & (2) & (3) & (4) & (5) & (6) \\
\hline Fraud $_{-t-3-\mathrm{t}} *$ FTA & $\begin{array}{c}-0.222^{* * *} \\
(0.061)\end{array}$ & & & $\begin{array}{c}-2.834^{* *} \\
(1.376)\end{array}$ & & \\
\hline FTA & $\begin{array}{c}-0.090^{* * *} \\
(0.015)\end{array}$ & & & $\begin{array}{c}-2.117^{* * *} \\
(0.517)\end{array}$ & & \\
\hline Fraud_t-3-t $*$ FDA & & $\begin{array}{c}-0.186^{* * *} \\
(0.064)\end{array}$ & & & $\begin{array}{c}-8.412^{* * *} \\
(2.930)\end{array}$ & \\
\hline FDA & & $\begin{array}{c}-0.107^{* * *} \\
(0.026)\end{array}$ & & & $\begin{array}{c}-3.140 * \\
(1.643)\end{array}$ & \\
\hline Fraud $_{-\mathrm{t}-3-\mathrm{t}} *(\mathrm{FTA}+\mathrm{FDA})$ & & & $\begin{array}{c}-0.254^{* * *} \\
(0.081)\end{array}$ & & & $\begin{array}{c}-4.773^{* *} \\
(2.320)\end{array}$ \\
\hline FTA+FDA & & & $\begin{array}{c}-0.166^{* * *} \\
(0.027)\end{array}$ & & & $\begin{array}{c}-4.617 * * * \\
(1.163)\end{array}$ \\
\hline Fraud $_{-t-3-t}$ & $\begin{array}{c}0.144 * * * \\
(0.041)\end{array}$ & $\begin{array}{c}0.071^{*} \\
(0.037)\end{array}$ & $\begin{array}{c}0.120 * * * \\
(0.047)\end{array}$ & $\begin{array}{c}1.597 * * \\
(0.722)\end{array}$ & $\begin{array}{c}0.788 \\
(0.571)\end{array}$ & $\begin{array}{l}1.333^{*} \\
(0.807)\end{array}$ \\
\hline Tobin's Q & $\begin{array}{l}-0.001 \\
(0.001)\end{array}$ & $\begin{array}{c}-0.000 \\
(0.001)\end{array}$ & $\begin{array}{c}-0.001 \\
(0.001)\end{array}$ & $\begin{array}{c}0.020 \\
(0.040)\end{array}$ & $\begin{array}{c}0.043 \\
(0.028)\end{array}$ & $\begin{array}{c}0.024 \\
(0.034)\end{array}$ \\
\hline Ebitda/TA & $\begin{array}{l}-0.031 \\
(0.048)\end{array}$ & $\begin{array}{l}-0.014 \\
(0.053)\end{array}$ & $\begin{array}{l}-0.021 \\
(0.054)\end{array}$ & $\begin{array}{c}-0.751 \\
(1.967)\end{array}$ & $\begin{array}{l}-1.131 \\
(2.146)\end{array}$ & $\begin{array}{l}-1.352 \\
(2.405)\end{array}$ \\
\hline SalesGrowth_3Yr & $\begin{array}{c}0.000 \\
(0.000)\end{array}$ & $\begin{array}{c}0.000 \\
(0.000)\end{array}$ & $\begin{array}{c}0.000 \\
(0.000)\end{array}$ & $\begin{array}{c}0.000 \\
(0.001)\end{array}$ & $\begin{array}{c}0.001 \\
(0.001)\end{array}$ & $\begin{array}{c}0.001 \\
(0.002)\end{array}$ \\
\hline Ln(TotalAssets) & $\begin{array}{c}0.004 \\
(0.010)\end{array}$ & $\begin{array}{c}0.010 \\
(0.013)\end{array}$ & $\begin{array}{c}0.010 \\
(0.013)\end{array}$ & $\begin{array}{c}-0.228 \\
(0.473)\end{array}$ & $\begin{array}{c}0.051 \\
(0.473)\end{array}$ & $\begin{array}{l}-0.206 \\
(0.534)\end{array}$ \\
\hline ICR & $\begin{array}{l}-0.035 \\
(0.073)\end{array}$ & $\begin{array}{l}-0.140 \\
(0.110)\end{array}$ & $\begin{array}{l}-0.122 \\
(0.111)\end{array}$ & $\begin{array}{l}-6.313^{*} \\
(3.751)\end{array}$ & $\begin{array}{l}-7.689 \\
(5.331)\end{array}$ & $\begin{array}{l}-8.485 \\
(5.808)\end{array}$ \\
\hline CEO_Founder & $\begin{array}{c}0.084^{* * *} \\
(0.024)\end{array}$ & $\begin{array}{c}0.098 * * * \\
(0.032)\end{array}$ & $\begin{array}{c}0.068 * * \\
(0.032)\end{array}$ & $\begin{array}{c}5.109 * * * \\
(1.837)\end{array}$ & $\begin{array}{c}6.256^{* * *} \\
(2.010)\end{array}$ & $\begin{array}{c}4.513^{* *} \\
(1.796)\end{array}$ \\
\hline CEO_Chair & $\begin{array}{l}-0.006 \\
(0.010)\end{array}$ & $\begin{array}{l}-0.010 \\
(0.014)\end{array}$ & $\begin{array}{l}-0.010 \\
(0.014)\end{array}$ & $\begin{array}{l}-0.294 \\
(0.290)\end{array}$ & $\begin{array}{l}-0.257 \\
(0.341)\end{array}$ & $\begin{array}{l}-0.424 \\
(0.345)\end{array}$ \\
\hline Ln(CEO_Age) & $\begin{array}{c}0.084 * * * \\
(0.026)\end{array}$ & $\begin{array}{c}0.104^{* * *} \\
(0.035)\end{array}$ & $\begin{array}{c}0.109 * * * \\
(0.034)\end{array}$ & $\begin{array}{c}2.081 * * * \\
(0.751)\end{array}$ & $\begin{array}{c}1.577 * * \\
(0.737)\end{array}$ & $\begin{array}{c}1.836 * * \\
(0.760)\end{array}$ \\
\hline Ln(BoardSize) & $\begin{array}{l}-0.022 \\
(0.019)\end{array}$ & $\begin{array}{l}-0.018 \\
(0.024)\end{array}$ & $\begin{array}{c}-0.028 \\
(0.023)\end{array}$ & $\begin{array}{c}-1.335^{*} \\
(0.804)\end{array}$ & $\begin{array}{l}-1.178 \\
(0.890)\end{array}$ & $\begin{array}{l}-1.437 \\
(0.930)\end{array}$ \\
\hline \%_NonIndepDirectors & $\begin{array}{l}-0.019 \\
(0.027)\end{array}$ & $\begin{array}{l}-0.031 \\
(0.032)\end{array}$ & $\begin{array}{c}-0.036 \\
(0.032)\end{array}$ & $\begin{array}{c}0.427 \\
(1.237)\end{array}$ & $\begin{array}{l}-0.809 \\
(1.417)\end{array}$ & $\begin{array}{c}-0.579 \\
(1.577)\end{array}$ \\
\hline Ln(BoardMeetings) & $\begin{array}{c}0.045^{* * *} \\
(0.012)\end{array}$ & $\begin{array}{c}0.045^{* * *} \\
(0.015)\end{array}$ & $\begin{array}{c}0.043^{* * *} \\
(0.014)\end{array}$ & $\begin{array}{c}0.971^{* *} \\
(0.405)\end{array}$ & $\begin{array}{l}0.705^{*} \\
(0.404)\end{array}$ & $\begin{array}{c}0.726^{*} \\
(0.438)\end{array}$ \\
\hline CEO_Tenure & $\begin{array}{c}-0.006^{* * *} \\
(0.001)\end{array}$ & $\begin{array}{c}-0.006^{* * *} \\
(0.002)\end{array}$ & $\begin{array}{l}-0.003 * \\
(0.002)\end{array}$ & $\begin{array}{c}-0.499 * * * \\
(0.138)\end{array}$ & $\begin{array}{c}-0.438 * * \\
(0.174)\end{array}$ & $\begin{array}{c}-0.301^{* *} \\
(0.132)\end{array}$ \\
\hline Ln(Analyst) & $\begin{array}{c}-0.017^{*} \\
(0.010)\end{array}$ & $\begin{array}{l}-0.013 \\
(0.013)\end{array}$ & $\begin{array}{l}-0.013 \\
(0.013)\end{array}$ & $\begin{array}{c}-0.850 * * \\
(0.386)\end{array}$ & $\begin{array}{c}-0.590 * \\
(0.353)\end{array}$ & $\begin{array}{c}-0.491 \\
(0.368)\end{array}$ \\
\hline IOC & $\begin{array}{c}0.084 * * * \\
(0.032)\end{array}$ & $\begin{array}{c}0.084 * * \\
(0.041)\end{array}$ & $\begin{array}{c}0.082 * * \\
(0.041)\end{array}$ & $\begin{array}{c}4.088^{* * *} \\
(1.519)\end{array}$ & $\begin{array}{c}3.585^{* *} \\
(1.500)\end{array}$ & $\begin{array}{l}2.677^{*} \\
(1.608)\end{array}$ \\
\hline IndustryLitigation & $\begin{array}{c}0.323^{* *} \\
(0.141)\end{array}$ & $\begin{array}{c}0.325^{* *} \\
(0.156)\end{array}$ & $\begin{array}{c}0.324 * * \\
(0.155)\end{array}$ & $\begin{array}{c}7.843^{* *} \\
(3.904)\end{array}$ & $\begin{array}{l}6.466^{*} \\
(3.712)\end{array}$ & $\begin{array}{c}7.075^{*} \\
(3.854)\end{array}$ \\
\hline CEO_Jail\&Bar & $\begin{array}{c}0.135 \\
(0.085)\end{array}$ & $\begin{array}{c}0.164 \\
(0.111)\end{array}$ & $\begin{array}{c}0.161 \\
(0.102)\end{array}$ & $\begin{array}{c}12.320^{* * *} \\
(1.601)\end{array}$ & $\begin{array}{c}18.710 * * * \\
(1.916)\end{array}$ & $\begin{array}{c}14.636 * * * \\
(1.670)\end{array}$ \\
\hline Constant & $\begin{array}{c}-0.232^{* *} \\
(0.101)\end{array}$ & $\begin{array}{l}-0.252 * \\
(0.135)\end{array}$ & $\begin{array}{c}-0.218 \\
(0.133)\end{array}$ & & & \\
\hline Firm FE & $\mathrm{Y}$ & $\mathrm{Y}$ & $\mathrm{Y}$ & $\mathrm{N}$ & $\mathrm{N}$ & $\mathrm{N}$ \\
\hline Year FE (Dummies) & $\mathrm{Y}$ & $\mathrm{Y}$ & $\mathrm{Y}$ & $\mathrm{Y}$ & $\mathrm{Y}$ & $\mathrm{Y}$ \\
\hline Observations & 8,265 & 6,546 & 6,546 & 1,325 & 1,001 & 1,001 \\
\hline Adjusted $\mathrm{R}^{2}$ & 0.115 & 0.116 & 0.131 & & & \\
\hline Wald & . & . & . & 327.4 & 331.2 & 328.0 \\
\hline
\end{tabular}


Table VIII. Fraud Detection Duration, the Hazard Ratio and Appointment-based CEO Connectedness.

This table relates appointment-based CEO connectedness to fraud detection duration and the hazard ratio. The sample covers 296 fraud cases over the period 1996 through 2006. Panels A and B report estimation results by the OLS and the Cox regressions, respectively. The dependent variable in Panel A is the logged value of the number of days from the commencement of fraudulent activity to the detection date; in Panel B, the hazard ratio for the Cox regression. All regressions control for industry dummies. CEO connectedness and control variables are their average values over the fraud period. Definitions of all variables are provided in Table I. Robust standard errors clustered at the industry level are reported in parenthesis. Industries are classified by Fama-French 48 industry groupings. Coefficients marked with *, **, and $* * *$ are significant at $10 \%, 5 \%, 1 \%$, respectively.

\begin{tabular}{|c|c|c|c|c|c|c|}
\hline \multirow[b]{2}{*}{ VARIABLES } & \multicolumn{3}{|c|}{ Panel A: Ln(Duration_Day) } & \multicolumn{3}{|c|}{ Panel B:_t } \\
\hline & (1) & $(2)$ & (3) & (4) & (5) & (6) \\
\hline FTA & $\begin{array}{c}0.312 * * \\
(0.146)\end{array}$ & & & $\begin{array}{c}-0.742^{* * *} \\
(0.194)\end{array}$ & & \\
\hline FDA & & $\begin{array}{l}0.439 * \\
(0.241)\end{array}$ & & & $\begin{array}{c}-0.676^{* *} \\
(0.315)\end{array}$ & \\
\hline FTA+FDA & & & $\begin{array}{c}0.624 * * \\
(0.265)\end{array}$ & & & $\begin{array}{c}-1.227 * * * \\
(0.397)\end{array}$ \\
\hline Tot_Settlement & $\begin{array}{c}0.001 * * * \\
(0.000)\end{array}$ & $\begin{array}{c}0.001^{* * *} \\
(0.000)\end{array}$ & $\begin{array}{c}0.001^{* * *} \\
(0.000)\end{array}$ & $\begin{array}{c}-0.001^{* * *} \\
(0.000)\end{array}$ & $\begin{array}{c}-0.001^{* * *} \\
(0.000)\end{array}$ & $\begin{array}{c}-0.001^{* * *} \\
(0.000)\end{array}$ \\
\hline Tot_Settlement_D & $\begin{array}{c}-0.643^{* * *} \\
(0.103)\end{array}$ & $\begin{array}{c}-0.582^{* * *} \\
(0.170)\end{array}$ & $\begin{array}{c}-0.585^{* * *} \\
(0.166)\end{array}$ & $\begin{array}{c}0.892^{* * *} \\
(0.154)\end{array}$ & $\begin{array}{c}0.789 * * * \\
(0.228)\end{array}$ & $\begin{array}{c}0.820 * * * \\
(0.221)\end{array}$ \\
\hline Ln(TotalAssets) & $\begin{array}{c}-0.058 * \\
(0.031)\end{array}$ & $\begin{array}{c}0.048 \\
(0.040)\end{array}$ & $\begin{array}{c}0.033 \\
(0.040)\end{array}$ & $\begin{array}{c}0.061 \\
(0.053)\end{array}$ & $\begin{array}{c}-0.146^{* *} \\
(0.061)\end{array}$ & $\begin{array}{c}-0.129 * * \\
(0.052)\end{array}$ \\
\hline StockReturns & $\begin{array}{c}0.413 * * * \\
(0.078)\end{array}$ & $\begin{array}{c}0.401^{* * *} \\
(0.124)\end{array}$ & $\begin{array}{c}0.374 * * * \\
(0.137)\end{array}$ & $\begin{array}{c}-0.846^{* * *} \\
(0.218)\end{array}$ & $\begin{array}{c}-1.124 * * * \\
(0.345)\end{array}$ & $\begin{array}{c}-1.026 * * * \\
(0.373)\end{array}$ \\
\hline Ebitda/TA & $\begin{array}{c}0.405 \\
(0.591)\end{array}$ & $\begin{array}{l}1.357 * * \\
(0.621)\end{array}$ & $\begin{array}{l}1.300^{*} \\
(0.659)\end{array}$ & $\begin{array}{l}-0.882 \\
(0.991)\end{array}$ & $\begin{array}{c}-2.954^{* * *} \\
(1.054)\end{array}$ & $\begin{array}{c}-2.894 * * * \\
(1.053)\end{array}$ \\
\hline Leverage & $\begin{array}{c}0.328 \\
(0.251)\end{array}$ & $\begin{array}{c}0.361 \\
(0.396)\end{array}$ & $\begin{array}{c}0.431 \\
(0.403)\end{array}$ & $\begin{array}{l}-0.203 \\
(0.398)\end{array}$ & $\begin{array}{l}-0.449 \\
(0.716)\end{array}$ & $\begin{array}{l}-0.489 \\
(0.618)\end{array}$ \\
\hline SalesGrowth_3Yr & $\begin{array}{l}0.000 * \\
(0.000)\end{array}$ & $\begin{array}{l}0.001 * \\
(0.000)\end{array}$ & $\begin{array}{c}0.001 * * \\
(0.000)\end{array}$ & $\begin{array}{c}0.000 \\
(0.000)\end{array}$ & $\begin{array}{c}0.000 \\
(0.000)\end{array}$ & $\begin{array}{l}-0.000 \\
(0.000)\end{array}$ \\
\hline StockVolatilities & $\begin{array}{l}-9.520 * \\
(5.093)\end{array}$ & $\begin{array}{l}-6.360 \\
(7.042)\end{array}$ & $\begin{array}{l}-7.017 \\
(7.164)\end{array}$ & $\begin{array}{c}4.849 \\
(7.073)\end{array}$ & $\begin{array}{c}-5.675 \\
(11.633)\end{array}$ & $\begin{array}{c}-3.119 \\
(11.199)\end{array}$ \\
\hline StockTurnover & $\begin{array}{c}0.015 \\
(0.025)\end{array}$ & $\begin{array}{c}0.036 \\
(0.041)\end{array}$ & $\begin{array}{c}0.041 \\
(0.040)\end{array}$ & $\begin{array}{l}-0.007 \\
(0.041)\end{array}$ & $\begin{array}{l}-0.053 \\
(0.060)\end{array}$ & $\begin{array}{l}-0.058 \\
(0.058)\end{array}$ \\
\hline IndustryLitigation & $\begin{array}{c}-5.865^{* * *} \\
(1.784)\end{array}$ & $\begin{array}{c}-6.097 * * * \\
(1.709)\end{array}$ & $\begin{array}{c}-6.169 * * * \\
(1.768)\end{array}$ & $\begin{array}{c}8.780 * * * \\
(2.477)\end{array}$ & $\begin{array}{c}7.916^{* * *} \\
(2.430)\end{array}$ & $\begin{array}{c}8.443 * * * \\
(2.421)\end{array}$ \\
\hline Ln(Analyst) & $\begin{array}{l}-0.093 \\
(0.065)\end{array}$ & $\begin{array}{c}-0.363^{* * *} \\
(0.098)\end{array}$ & $\begin{array}{c}-0.367^{* * *} \\
(0.097)\end{array}$ & $\begin{array}{l}0.166^{*} \\
(0.092)\end{array}$ & $\begin{array}{c}0.559 * * * \\
(0.127)\end{array}$ & $\begin{array}{c}0.601^{* * *} \\
(0.131)\end{array}$ \\
\hline CEO_Chair & $\begin{array}{c}0.123 \\
(0.128)\end{array}$ & $\begin{array}{c}0.052 \\
(0.132)\end{array}$ & $\begin{array}{c}0.040 \\
(0.130)\end{array}$ & $\begin{array}{l}-0.247 \\
(0.202)\end{array}$ & $\begin{array}{l}-0.244 \\
(0.221)\end{array}$ & $\begin{array}{l}-0.200 \\
(0.218)\end{array}$ \\
\hline CEO_Founder & $\begin{array}{l}-0.182 \\
(0.262)\end{array}$ & $\begin{array}{l}-0.307 \\
(0.383)\end{array}$ & $\begin{array}{l}-0.280 \\
(0.383)\end{array}$ & $\begin{array}{c}0.393 \\
(0.470)\end{array}$ & $\begin{array}{c}0.368 \\
(0.522)\end{array}$ & $\begin{array}{c}0.380 \\
(0.510)\end{array}$ \\
\hline CEO_Tenure & $\begin{array}{l}0.017 * \\
(0.009)\end{array}$ & $\begin{array}{c}0.014 \\
(0.014)\end{array}$ & $\begin{array}{c}0.012 \\
(0.013)\end{array}$ & $\begin{array}{c}-0.036 * * \\
(0.016)\end{array}$ & $\begin{array}{l}-0.026 \\
(0.017)\end{array}$ & $\begin{array}{l}-0.021 \\
(0.016)\end{array}$ \\
\hline CEO_OWN & $\begin{array}{l}-0.846 \\
(2.110)\end{array}$ & $\begin{array}{l}-2.840 \\
(3.492)\end{array}$ & $\begin{array}{l}-2.012 \\
(3.366)\end{array}$ & $\begin{array}{l}-1.944 \\
(3.603)\end{array}$ & $\begin{array}{c}2.229 \\
(4.432)\end{array}$ & $\begin{array}{c}0.593 \\
(4.350)\end{array}$ \\
\hline$\left(\mathrm{CEO} \_\mathrm{OWN}\right)^{2}$ & $\begin{array}{c}3.246 \\
(7.751)\end{array}$ & $\begin{array}{c}7.860 \\
(12.030)\end{array}$ & $\begin{array}{c}5.120 \\
(11.238)\end{array}$ & $\begin{array}{c}4.958 \\
(11.944)\end{array}$ & $\begin{array}{c}-5.072 \\
(15.764)\end{array}$ & $\begin{array}{c}-0.625 \\
(15.170)\end{array}$ \\
\hline Constant & $\begin{array}{c}7.524 * * * \\
(0.263)\end{array}$ & $\begin{array}{c}7.704^{* * *} \\
(0.380)\end{array}$ & $\begin{array}{c}7.627 * * * \\
(0.377)\end{array}$ & & & \\
\hline Industry Dummies & $\mathrm{Y}$ & $\mathrm{Y}$ & $\mathrm{Y}$ & $\mathrm{Y}$ & $\mathrm{Y}$ & $\mathrm{Y}$ \\
\hline Observations & 296 & 228 & 228 & 296 & 228 & 228 \\
\hline Adjusted $\mathrm{R}^{2}$ & 0.287 & 0.279 & 0.287 & & & \\
\hline Wald & & & & 56606 & 16643 & 12816 \\
\hline
\end{tabular}


Table IX: Number of People Charged and Appointment-based CEO Connectedness.

This table estimates the relations between appointment-based CEO connectedness and the number of people charged in litigation or enforcement actions. The dependent variable, Ln(Num_Charged+1), is the logged value of the number of people charged in litigation or enforcement actions plus one. The sample covers 308 fraud cases over the period 1996 through 2006. The CEO connectedness variables and the control variables are their average values over the fraud period. All regressions control for industry dummies. Definitions of all variables are provided in Table I. Robust standard errors clustered at the industry level are reported in parentheses. Industries are classified by Fama-French 48 industry groupings. Coefficients marked with $*$, ${ }^{* *}$, and $* * *$ are significant at $10 \%, 5 \%, 1 \%$, respectively.

\begin{tabular}{|c|c|c|c|}
\hline \multirow[b]{2}{*}{ VARIABLES } & \multicolumn{3}{|c|}{ Ln(Num_Charged+1) } \\
\hline & (1) & (2) & (3) \\
\hline FTA & $\begin{array}{c}0.181^{* *} \\
(0.089)\end{array}$ & & \\
\hline FDA & & $\begin{array}{c}0.558 * * \\
(0.265)\end{array}$ & \\
\hline FTA+FDA & & & $\begin{array}{c}0.600 * * \\
(0.245)\end{array}$ \\
\hline Tobin's Q & $\begin{array}{l}-0.000 \\
(0.005)\end{array}$ & $\begin{array}{l}-0.006 \\
(0.006)\end{array}$ & $\begin{array}{l}-0.005 \\
(0.006)\end{array}$ \\
\hline Ebitda/TA & $\begin{array}{c}0.415 \\
(0.249)\end{array}$ & $\begin{array}{c}0.418 \\
(0.297)\end{array}$ & $\begin{array}{c}0.287 \\
(0.274)\end{array}$ \\
\hline SalesGrowth_3Yr & $\begin{array}{c}0.000 \\
(0.000)\end{array}$ & $\begin{array}{c}0.000^{* * *} \\
(0.000)\end{array}$ & $\begin{array}{c}0.000^{* * *} \\
(0.000)\end{array}$ \\
\hline Leverage & $\begin{array}{c}0.296 \\
(0.223)\end{array}$ & $\begin{array}{l}0.320^{*} \\
(0.182)\end{array}$ & $\begin{array}{c}0.315^{*} \\
(0.180)\end{array}$ \\
\hline Accounting & $\begin{array}{l}0.330 * \\
(0.170)\end{array}$ & $\begin{array}{l}0.264^{*} \\
(0.148)\end{array}$ & $\begin{array}{l}0.292^{*} \\
(0.153)\end{array}$ \\
\hline Operating & $\begin{array}{l}0.183 * * \\
(0.072)\end{array}$ & $\begin{array}{c}0.125 \\
(0.104)\end{array}$ & $\begin{array}{c}0.103 \\
(0.097)\end{array}$ \\
\hline Executive & $\begin{array}{c}0.185 * * \\
(0.079)\end{array}$ & $\begin{array}{c}0.126 \\
(0.100)\end{array}$ & $\begin{array}{c}0.110 \\
(0.099)\end{array}$ \\
\hline CEO_Tenure & $\begin{array}{c}0.002 \\
(0.006)\end{array}$ & $\begin{array}{l}-0.009 \\
(0.006)\end{array}$ & $\begin{array}{l}-0.005 \\
(0.006)\end{array}$ \\
\hline Tot_Settlement & $\begin{array}{c}0.002 * * * \\
(0.000)\end{array}$ & $\begin{array}{c}0.002^{* * *} \\
(0.000)\end{array}$ & $\begin{array}{c}0.002 * * * \\
(0.000)\end{array}$ \\
\hline Tot_Settlement_D & $\begin{array}{c}0.070 \\
(0.086)\end{array}$ & $\begin{array}{c}0.028 \\
(0.096)\end{array}$ & $\begin{array}{c}0.025 \\
(0.091)\end{array}$ \\
\hline Constant & $\begin{array}{c}0.995^{* * *} \\
(0.220)\end{array}$ & $\begin{array}{c}1.090 * * * \\
(0.225)\end{array}$ & $\begin{array}{c}1.012^{* * *} \\
(0.247)\end{array}$ \\
\hline Industry Dummies & $\mathrm{Y}$ & $\mathrm{Y}$ & $\mathrm{Y}$ \\
\hline Observations & 308 & 234 & 234 \\
\hline Adjusted $\mathrm{R}^{2}$ & 0.096 & 0.116 & 0.117 \\
\hline
\end{tabular}


Table X: Interactive Effects of Appointment-based CEO Connectedness and Monitoring on Corporate Frauds.

This table reports the bivariate probit model estimation results of interactive effects of appointment-based CEO connectedness and monitoring mechanisms on corporate frauds. Panels A, B, and C report the estimated interactive effects for board independence, audit committee independence, and institutional investor concentration, respectively. Control variables are identical to those in Table V but their coefficients are not reported. Definitions of all variables are provided in Table I. All regressions include year dummies. Robust standard errors clustered at the industry level are reported in parentheses. Industries are classified by Fama-French 48 industry groupings. Coefficients marked with *, **, and *** are significant at $10 \%, 5 \%, 1 \%$, respectively.

\begin{tabular}{|c|c|c|c|c|}
\hline \multicolumn{5}{|c|}{ Panel A: Interaction with Board Independence } \\
\hline & Fraud & Detect|Fraud & Fraud & Detect|Fraud \\
\hline VARIABLES & (1) & (2) & (3) & (4) \\
\hline FTA & $\begin{array}{c}0.006 \\
(0.227)\end{array}$ & $\begin{array}{l}-0.337 \\
(0.288)\end{array}$ & & \\
\hline FDA & & & $\begin{array}{c}0.684 \\
(0.925)\end{array}$ & $\begin{array}{l}-0.262 \\
(0.806)\end{array}$ \\
\hline FTA*\%_NonIndepDirectors & $\begin{array}{c}0.639 \\
(0.663)\end{array}$ & $\begin{array}{l}-1.390 \\
(0.922)\end{array}$ & & \\
\hline FDA*\%_NonIndepDirectors & & & $\begin{array}{c}2.686 \\
(2.253)\end{array}$ & $\begin{array}{c}-3.180 \\
(2.048)\end{array}$ \\
\hline \%_NonIndepDirectors & $\begin{array}{c}-0.765^{*} \\
(0.423)\end{array}$ & $\begin{array}{c}2.807 * * * \\
(0.650)\end{array}$ & $\begin{array}{c}-4.012 * * * \\
(1.373)\end{array}$ & $\begin{array}{c}3.962 * * * \\
(1.304)\end{array}$ \\
\hline Year Dummies & $\mathrm{Y}$ & $\mathrm{Y}$ & $\mathrm{Y}$ & $\mathrm{Y}$ \\
\hline Observations & 7,871 & 7,871 & 6,250 & 6,250 \\
\hline Prob $>\mathrm{Ch}^{\mathrm{i} 2}$ & 0.000 & 0.000 & 0.000 & 0.000 \\
\hline log likelihood & -1257 & -1257 & -1096 & -1096 \\
\hline \multicolumn{5}{|c|}{ Panel B: Interaction with Audit Committee Independence } \\
\hline FTA & $\begin{array}{c}0.867 * * * \\
(0.286)\end{array}$ & $\begin{array}{c}-0.829 * * * \\
(0.280)\end{array}$ & & \\
\hline FDA & & & $\begin{array}{c}0.806 \\
(0.688)\end{array}$ & $\begin{array}{l}-0.604 \\
(0.547)\end{array}$ \\
\hline FTA*\%_NonIndepDirectors_Audit & $\begin{array}{l}4.508^{*} \\
(2.303)\end{array}$ & $\begin{array}{l}-3.846 * \\
(2.102)\end{array}$ & & \\
\hline FDA*\%_NonIndepDirectors_Audit & & & $\begin{array}{l}9.047^{*} \\
(5.352)\end{array}$ & $\begin{array}{c}-8.776^{*} \\
(4.952)\end{array}$ \\
\hline \%_NonIndepDirectors_Audit & $\begin{array}{l}-3.749 * \\
(2.023)\end{array}$ & $\begin{array}{c}3.058 \\
(2.390)\end{array}$ & $\begin{array}{l}-2.410 \\
(2.685)\end{array}$ & $\begin{array}{c}2.428 \\
(2.696)\end{array}$ \\
\hline Year Dummies & $\mathrm{Y}$ & $\mathrm{Y}$ & $\mathrm{Y}$ & $\mathrm{Y}$ \\
\hline Observations & 7,871 & 7,871 & 6,250 & 6,250 \\
\hline Prob $>$ Chi $^{2}$ & 0.000 & 0.000 & 0.000 & 0.000 \\
\hline log likelihood & -1252 & -1252 & -1097 & -1097 \\
\hline \multicolumn{5}{|l|}{ Panel C: Interaction with IOC } \\
\hline FTA & $\begin{array}{c}0.501 \\
(0.743)\end{array}$ & $\begin{array}{l}-0.326 \\
(0.579)\end{array}$ & & \\
\hline FDA & & & $\begin{array}{c}0.160 \\
(0.563)\end{array}$ & $\begin{array}{c}0.235 \\
(0.675)\end{array}$ \\
\hline FTA*IOC & $\begin{array}{c}1.562 \\
(2.173)\end{array}$ & $\begin{array}{l}-1.839 \\
(1.962)\end{array}$ & & \\
\hline FDA*IOC & & & $\begin{array}{c}1.973 \\
(1.366)\end{array}$ & $\begin{array}{c}-4.039 * * \\
(1.432)\end{array}$ \\
\hline IOC & $\begin{array}{l}-1.887 \\
(1.309)\end{array}$ & $\begin{array}{l}2.267 * \\
(1.281)\end{array}$ & $\begin{array}{l}-0.465 \\
(0.683)\end{array}$ & $\begin{array}{c}3.178 * * * \\
(0.957)\end{array}$ \\
\hline Year Dummies & $\mathrm{Y}$ & $\mathrm{Y}$ & $\mathrm{Y}$ & $\mathrm{Y}$ \\
\hline Observations & 7,871 & 7,871 & 6,250 & 6,250 \\
\hline Prob $>\mathrm{Chi}^{2}$ & 0.000 & 0.000 & 0.000 & 0.000 \\
\hline log likelihood & -1252 & -1252 & -1102 & -1102 \\
\hline
\end{tabular}




\section{Appendix}

Appendices 1 through 6 contain estimation results of robustness tests to alternative bivariate probit specifications, alternative measures of appointment-based CEO connectedness, separating directors into independent and non-independent directors, and an alternative sample construction. Appendices 7 through 9 contain re-estimation results employing pre-existing network ties and a CEO power index in place of appointment-based CEO connectedness measures.

Appendix 1: Alternative specifications of the bivariate probit model estimation.

$>$ Panel A: Excluding monitoring variables from the fraud incidence regression.

$>$ Panel B: Controlling ICR in both fraud incidence and detection regressions.

$>$ Panel C: Controlling for firm organizational changes.

$>$ Panel D: Alternative clustering standard errors.

Appendix 2: Abnormal measures of appointment-based CEO connectedness.

Appendix 3: Tenure-weighted appointment-based CEO connectedness variables.

Appendix 4: Compensation-weighted appointment-based CEO connectedness variables.

Appendix 5: Separating directors into independent and non-independent directors.

Appendix 6: Fraud sample including CEO-unnamed fraud cases.

Appendix 7: Pre-existing network ties between the CEO and top executives.

Appendix 8: Pre-existing network ties between the CEO and directors.

Appendix 9: A CEO power index consisting of indicators for CEO-chair, founder-CEO, high CEO share ownership, and long CEO tenure. 
Appendix 1, Panel A: Alternative Specification for the Bivariate Probit Model Estimation - Excluding monitoring variables from the fraud incidence regression.

This table reports re-estimation results of the bivariate probit model while excluding monitoring variables from the fraud incidence regression. Coefficients marked with *, ** and *** are significant at $10 \%, 5 \%, 1 \%$, respectively.

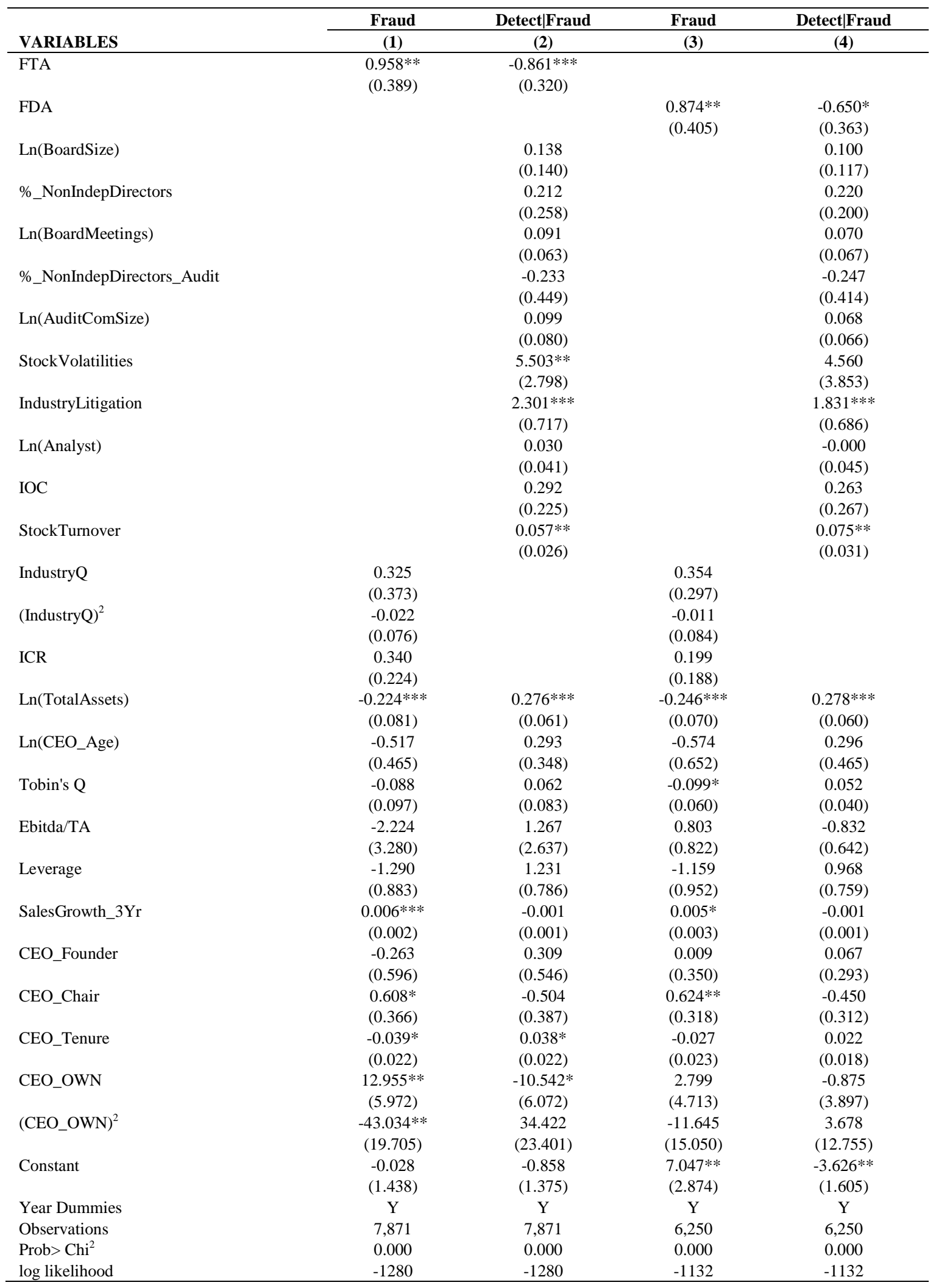


Appendix 1, Panel B: Alternative Specification for Bivariate Probit Model Estimation - Controlling ICR in Both Fraud and Detection Regressions

This table reports re-estimation results of the bivariate probit model while controlling ICR in both fraud incidence and detection regressions. Coefficients marked with *, ** and *** are significant at $10 \%, 5 \%, 1 \%$, respectively.

\begin{tabular}{|c|c|c|c|c|}
\hline & Fraud & Detect|Fraud & Fraud & Detect|Fraud \\
\hline VARIABLES & (1) & (2) & (3) & (4) \\
\hline FTA & $\begin{array}{c}0.915^{* * *} \\
(0.276)\end{array}$ & $\begin{array}{c}-0.898^{* * *} \\
(0.262)\end{array}$ & & \\
\hline FDA & & & $\begin{array}{l}1.332 * \\
(0.684)\end{array}$ & $\begin{array}{c}-1.244 * * \\
(0.553)\end{array}$ \\
\hline Tobin's Q & $\begin{array}{c}-0.245^{* * *} \\
(0.086)\end{array}$ & $\begin{array}{c}0.225 * * * \\
(0.084)\end{array}$ & $\begin{array}{c}-0.345^{* * *} \\
(0.103)\end{array}$ & $\begin{array}{c}0.319 * * * \\
(0.093)\end{array}$ \\
\hline Ebitda/TA & $\begin{array}{c}0.327 \\
(1.404)\end{array}$ & $\begin{array}{c}-0.857 \\
(1.187)\end{array}$ & $\begin{array}{l}2.087^{*} \\
(1.264)\end{array}$ & $\begin{array}{l}-2.258 \\
(1.374)\end{array}$ \\
\hline Leverage & $\begin{array}{c}-0.692 \\
(1.041)\end{array}$ & $\begin{array}{c}0.707 \\
(0.966)\end{array}$ & $\begin{array}{l}-1.297 \\
(1.374)\end{array}$ & $\begin{array}{c}1.287 \\
(1.341)\end{array}$ \\
\hline SalesGrowth_3Yr & $\begin{array}{c}0.013 * * * \\
(0.004)\end{array}$ & $\begin{array}{c}-0.008 * * \\
(0.003)\end{array}$ & $\begin{array}{c}0.015^{* * * *} \\
(0.004)\end{array}$ & $\begin{array}{c}-0.009 * * \\
(0.004)\end{array}$ \\
\hline Ln(TotalAssets) & $\begin{array}{l}-0.079 \\
(0.103)\end{array}$ & $\begin{array}{c}0.163 \\
(0.105)\end{array}$ & $\begin{array}{l}-0.037 \\
(0.134)\end{array}$ & $\begin{array}{c}0.127 \\
(0.133)\end{array}$ \\
\hline IndustryQ & $\begin{array}{c}0.227 \\
(0.385)\end{array}$ & & $\begin{array}{c}0.165 \\
(0.297)\end{array}$ & \\
\hline$(\text { IndustryQ) })^{2}$ & $\begin{array}{l}-0.007 \\
(0.084)\end{array}$ & & $\begin{array}{c}0.012 \\
(0.068)\end{array}$ & \\
\hline ICR & $\begin{array}{c}1.781 \\
(1.325)\end{array}$ & $\begin{array}{l}-1.360 \\
(1.257)\end{array}$ & $\begin{array}{c}2.128 \\
(2.649)\end{array}$ & $\begin{array}{l}-1.781 \\
(2.390)\end{array}$ \\
\hline CEO_OWN & $\begin{array}{c}7.937 \\
(8.897)\end{array}$ & $\begin{array}{l}-6.916 \\
(7.751)\end{array}$ & $\begin{array}{c}0.158 \\
(9.082)\end{array}$ & $\begin{array}{c}0.449 \\
(8.395)\end{array}$ \\
\hline$\left(\mathrm{CEO} \_\mathrm{OWN}\right)^{2}$ & $\begin{array}{l}-19.434 \\
(22.478)\end{array}$ & $\begin{array}{c}15.304 \\
(19.281)\end{array}$ & $\begin{array}{c}1.206 \\
(19.405)\end{array}$ & $\begin{array}{c}-4.619 \\
(17.615)\end{array}$ \\
\hline CEO_Founder & $\begin{array}{c}0.304 \\
(0.467)\end{array}$ & $\begin{array}{c}-0.188 \\
(0.444)\end{array}$ & $\begin{array}{c}0.323 \\
(0.784)\end{array}$ & $\begin{array}{l}-0.240 \\
(0.697)\end{array}$ \\
\hline CEO_Chair & $\begin{array}{c}0.121 \\
(0.310)\end{array}$ & $\begin{array}{l}-0.105 \\
(0.257)\end{array}$ & $\begin{array}{c}0.111 \\
(0.426)\end{array}$ & $\begin{array}{l}-0.092 \\
(0.346)\end{array}$ \\
\hline Ln(CEO_Age) & $\begin{array}{l}-0.081 \\
(0.444)\end{array}$ & $\begin{array}{l}-0.069 \\
(0.430)\end{array}$ & $\begin{array}{c}0.044 \\
(0.637)\end{array}$ & $\begin{array}{l}-0.120 \\
(0.610)\end{array}$ \\
\hline Ln(BoardSize) & $\begin{array}{c}-2.527 * * * \\
(0.566)\end{array}$ & $\begin{array}{c}2.496 * * * \\
(0.664)\end{array}$ & $\begin{array}{c}-3.177 * * * \\
(0.530)\end{array}$ & $\begin{array}{c}3.059 * * * \\
(0.592)\end{array}$ \\
\hline \%_NonIndepDirectors & $\begin{array}{c}-1.675^{*} \\
(0.890)\end{array}$ & $\begin{array}{l}1.817 * * \\
(0.806)\end{array}$ & $\begin{array}{l}-2.256^{*} \\
(1.353)\end{array}$ & $\begin{array}{l}2.318^{* *} \\
(1.171)\end{array}$ \\
\hline Ln(BoardMeetings) & $\begin{array}{l}-0.029 \\
(0.382)\end{array}$ & $\begin{array}{c}0.125 \\
(0.372)\end{array}$ & $\begin{array}{l}-0.257 \\
(0.467)\end{array}$ & $\begin{array}{c}0.322 \\
(0.413)\end{array}$ \\
\hline \%_NonIndepDirectors_Audit & $\begin{array}{l}-3.120 \\
(2.133)\end{array}$ & $\begin{array}{c}2.597 \\
(2.483)\end{array}$ & $\begin{array}{l}-2.227 \\
(2.970)\end{array}$ & $\begin{array}{c}1.785 \\
(2.947)\end{array}$ \\
\hline Ln(AuditComSize) & $\begin{array}{c}0.783 \\
(0.517)\end{array}$ & $\begin{array}{l}-0.590 \\
(0.556)\end{array}$ & $\begin{array}{c}0.813 \\
(0.619)\end{array}$ & $\begin{array}{l}-0.665 \\
(0.597)\end{array}$ \\
\hline StockVolatilities & $\begin{array}{c}5.306 \\
(11.678)\end{array}$ & $\begin{array}{l}-0.460 \\
(9.484)\end{array}$ & $\begin{array}{c}4.707 \\
(10.909)\end{array}$ & $\begin{array}{l}-0.275 \\
(9.581)\end{array}$ \\
\hline IndustryLitigation & $\begin{array}{c}13.515^{* * * *} \\
(4.592)\end{array}$ & $\begin{array}{c}-9.327^{* *} \\
(4.316)\end{array}$ & $\begin{array}{l}10.098^{*} \\
(5.631)\end{array}$ & $\begin{array}{l}-6.738 \\
(4.991)\end{array}$ \\
\hline CEO_Tenure & $\begin{array}{l}-0.024 \\
(0.023)\end{array}$ & $\begin{array}{c}0.026 \\
(0.022)\end{array}$ & $\begin{array}{c}-0.039 \\
0.189\end{array}$ & $\begin{array}{c}0.040 \\
-0.191\end{array}$ \\
\hline Ln(Analyst) & $\begin{array}{l}-0.073 \\
(0.237)\end{array}$ & $\begin{array}{c}0.093 \\
(0.200)\end{array}$ & $\begin{array}{l}(0.280) \\
-0.698\end{array}$ & $\begin{array}{c}(0.257) \\
0.972\end{array}$ \\
\hline IOC & $\begin{array}{l}-1.137 \\
(1.147)\end{array}$ & $\begin{array}{c}1.455 \\
(1.049)\end{array}$ & $\begin{array}{c}(1.021) \\
-0.186 * * *\end{array}$ & $\begin{array}{c}(0.938) \\
0.228 * * *\end{array}$ \\
\hline StockTurnover & $\begin{array}{c}-0.199 * * * \\
(0.039)\end{array}$ & $\begin{array}{c}0.245^{* * * *} \\
(0.033)\end{array}$ & $\begin{array}{c}(0.060) \\
0.189\end{array}$ & $\begin{array}{c}(0.068) \\
-0.191\end{array}$ \\
\hline Constant & $\begin{array}{l}5.696 * * \\
(2.506)\end{array}$ & $\begin{array}{c}-6.291^{* * * *} \\
(1.945)\end{array}$ & $\begin{array}{c}8.240 * * \\
(3.353)\end{array}$ & $\begin{array}{c}-8.649 * * * \\
(2.779)\end{array}$ \\
\hline Year Dummies & $\mathrm{Y}$ & $\mathrm{Y}$ & $\mathrm{Y}$ & $\mathrm{Y}$ \\
\hline Observations & 7,871 & 7,871 & 6,250 & 6,250 \\
\hline Prob $>\mathrm{Chi}^{2}$ & 0.000 & 0.000 & 0.000 & 0.000 \\
\hline log likelihood & -1251 & -1251 & -1103 & -1103 \\
\hline
\end{tabular}


Appendix 1, Panel C: Alternative Specification for Bivariate Probit Model Estimation - Controlling for Firm Organizational Changes.

This table reports re-estimation results of the bivariate probit model while controlling organizational changes triggered by mergers and acquisitions (MA) and divestitures and spinoffs (DS). $\mathrm{MA}_{\mathrm{t}-1}$ and $\mathrm{DS}_{\mathrm{t}-1}$ are the number of mergers and acquisitions and divestitures and spinoffs completed by a firm in the previous year. Other control variables in the fraud and detection regressions are identical to those in Table V. Coefficients marked with *, ** and *** are significant at $10 \%, 5 \%, 1 \%$, respectively.

\begin{tabular}{|c|c|c|c|c|}
\hline & Fraud & Detect|Fraud & Fraud & Detect|Fraud \\
\hline VARIABLES & (1) & (2) & (3) & (4) \\
\hline FTA & $\begin{array}{c}1.080^{* * * *} \\
(0.234)\end{array}$ & $\begin{array}{c}-1.028^{* * *} \\
(0.251)\end{array}$ & & \\
\hline FDA & & & $\begin{array}{c}1.006^{* * *} \\
(0.204)\end{array}$ & $\begin{array}{c}-1.267^{* * *} \\
(0.173)\end{array}$ \\
\hline $\mathrm{MA}_{\mathrm{t}-1}$ & $\begin{array}{c}-0.005 \\
(0.014)\end{array}$ & $\begin{array}{c}0.028 * * \\
(0.013)\end{array}$ & $\begin{array}{c}0.029 \\
(0.021)\end{array}$ & $\begin{array}{c}0.017 \\
(0.021)\end{array}$ \\
\hline $\mathrm{DS}_{\mathrm{t}-1}$ & $\begin{array}{c}0.039 \\
(0.048)\end{array}$ & $\begin{array}{l}-0.018 \\
(0.046)\end{array}$ & $\begin{array}{l}0.043^{*} \\
(0.025)\end{array}$ & $\begin{array}{c}0.036 \\
(0.026)\end{array}$ \\
\hline Tobin's Q & $\begin{array}{c}-0.237 * * * \\
(0.081)\end{array}$ & $\begin{array}{c}0.215^{* * *} \\
(0.074)\end{array}$ & $\begin{array}{c}-0.212^{* * *} \\
(0.044)\end{array}$ & $\begin{array}{c}0.328 * * * \\
(0.044)\end{array}$ \\
\hline Ebitda/TA & $\begin{array}{c}0.585 \\
(1.299)\end{array}$ & $\begin{array}{l}-1.060 \\
(1.107)\end{array}$ & $\begin{array}{c}0.447 \\
(0.369)\end{array}$ & $\begin{array}{c}-2.290^{* * *} \\
(0.544)\end{array}$ \\
\hline Leverage & $\begin{array}{l}-0.075 \\
(0.954)\end{array}$ & $\begin{array}{c}0.149 \\
(0.874)\end{array}$ & $\begin{array}{c}-0.536^{* * *} \\
(0.186)\end{array}$ & $\begin{array}{c}1.382^{* * * *} \\
(0.279)\end{array}$ \\
\hline SalesGrowth_3Yr & $\begin{array}{c}0.013^{* * *} \\
(0.003)\end{array}$ & $\begin{array}{c}-0.007^{* *} \\
(0.003)\end{array}$ & $\begin{array}{c}0.013 * * * \\
(0.002)\end{array}$ & $\begin{array}{c}-0.004^{* *} \\
(0.002)\end{array}$ \\
\hline Ln(TotalAssets) & $\begin{array}{l}-0.126^{*} \\
(0.074)\end{array}$ & $\begin{array}{c}0.190 * * * \\
(0.067)\end{array}$ & $\begin{array}{c}0.170^{* * *} \\
(0.044)\end{array}$ & $\begin{array}{c}0.184 * * * \\
(0.043)\end{array}$ \\
\hline IndustryQ & $\begin{array}{c}0.145 \\
(0.295)\end{array}$ & & $\begin{array}{c}1.087 * * * \\
(0.230)\end{array}$ & \\
\hline$(\text { IndustryQ) })^{2}$ & $\begin{array}{c}0.009 \\
(0.066)\end{array}$ & & $\begin{array}{c}-0.152^{* * *} \\
(0.051)\end{array}$ & \\
\hline ICR & $\begin{array}{c}0.239 \\
(0.169)\end{array}$ & & $\begin{array}{c}0.686^{* * *} \\
(0.116)\end{array}$ & \\
\hline CEO_OWN & $\begin{array}{c}6.784 \\
(8.396)\end{array}$ & $\begin{array}{c}-5.844 \\
(7.305)\end{array}$ & $\begin{array}{c}2.722 \\
(2.756)\end{array}$ & $\begin{array}{c}1.718 \\
(2.714)\end{array}$ \\
\hline$\left(\mathrm{CEO} \_\mathrm{OWN}\right)^{2}$ & $\begin{array}{l}-18.750 \\
(21.448)\end{array}$ & $\begin{array}{c}14.670 \\
(18.658)\end{array}$ & $\begin{array}{c}-7.991 \\
(10.867)\end{array}$ & $\begin{array}{l}-11.718 \\
(10.422)\end{array}$ \\
\hline CEO_Founder & $\begin{array}{c}0.502 \\
(0.461)\end{array}$ & $\begin{array}{l}-0.371 \\
(0.446)\end{array}$ & $\begin{array}{c}0.178 \\
(0.135)\end{array}$ & $\begin{array}{c}0.124 \\
(0.163)\end{array}$ \\
\hline CEO_Chair & $\begin{array}{c}0.211 \\
(0.288)\end{array}$ & $\begin{array}{c}-0.187 \\
(0.246)\end{array}$ & $\begin{array}{c}0.041 \\
(0.154)\end{array}$ & $\begin{array}{c}-0.119 \\
(0.122)\end{array}$ \\
\hline Ln(CEO_Age) & $\begin{array}{c}-0.058 \\
(0.440)\end{array}$ & $\begin{array}{l}-0.076 \\
(0.433)\end{array}$ & $\begin{array}{c}-0.494^{* * *} \\
(0.162)\end{array}$ & $\begin{array}{c}0.199 \\
(0.176)\end{array}$ \\
\hline Ln(BoardSize) & $\begin{array}{c}-2.419 * * * \\
(0.546)\end{array}$ & $\begin{array}{c}2.356^{* * *} \\
(0.535)\end{array}$ & $\begin{array}{c}-0.944^{* * *} \\
(0.251)\end{array}$ & $\begin{array}{c}2.175^{* * * *} \\
(0.278)\end{array}$ \\
\hline \%_NonIndepDirectors & $\begin{array}{c}-1.854^{* *} \\
(0.748)\end{array}$ & $\begin{array}{c}1.941^{* * *} \\
(0.694)\end{array}$ & $\begin{array}{l}-0.456 \\
(0.426)\end{array}$ & $\begin{array}{c}1.644 * * * \\
(0.474)\end{array}$ \\
\hline Ln(BoardMeetings) & $\begin{array}{l}-0.080 \\
(0.348)\end{array}$ & $\begin{array}{c}0.156 \\
(0.326)\end{array}$ & $\begin{array}{c}0.299 * * \\
(0.138)\end{array}$ & $\begin{array}{c}0.016 \\
(0.118)\end{array}$ \\
\hline \%_NonIndepDirectors_Audit & $\begin{array}{l}-2.604 \\
(2.053)\end{array}$ & $\begin{array}{c}2.119 \\
(2.253)\end{array}$ & $\begin{array}{l}-1.153 \\
(0.858)\end{array}$ & $\begin{array}{c}0.449 \\
(0.956)\end{array}$ \\
\hline Ln(AuditComSize) & $\begin{array}{c}0.651 \\
(0.424)\end{array}$ & $\begin{array}{c}-0.477 \\
(0.431)\end{array}$ & $\begin{array}{c}0.865^{* * *} \\
(0.209)\end{array}$ & $\begin{array}{c}-1.145^{* * *} \\
(0.220)\end{array}$ \\
\hline StockVolatilities & $\begin{array}{c}8.223 \\
(11.833)\end{array}$ & $\begin{array}{l}-3.525 \\
(9.454)\end{array}$ & $\begin{array}{c}19.410^{* * *} \\
(4.841)\end{array}$ & $\begin{array}{l}-7.030^{*} \\
(3.766)\end{array}$ \\
\hline IndustryLitigation & $\begin{array}{c}12.403 * * * \\
(3.790)\end{array}$ & $\begin{array}{c}-8.449 * * \\
(3.371)\end{array}$ & $\begin{array}{c}3.320 * * \\
(1.314)\end{array}$ & $\begin{array}{l}2.055^{*} \\
(1.057)\end{array}$ \\
\hline CEO_Tenure & $\begin{array}{l}-0.036 \\
(0.023)\end{array}$ & $\begin{array}{c}0.036 \\
(0.023)\end{array}$ & $\begin{array}{l}-0.012 \\
(0.009)\end{array}$ & $\begin{array}{c}0.025^{* * *} \\
(0.009)\end{array}$ \\
\hline Ln(Analyst) & $\begin{array}{c}-0.138 \\
(0.227)\end{array}$ & $\begin{array}{c}0.131 \\
(0.193)\end{array}$ & $\begin{array}{c}0.033 \\
(0.080)\end{array}$ & $\begin{array}{l}-0.032 \\
(0.092)\end{array}$ \\
\hline IOC & $\begin{array}{l}-1.052 \\
(1.182)\end{array}$ & $\begin{array}{c}1.351 \\
(1.094)\end{array}$ & $\begin{array}{c}0.334 \\
(0.447)\end{array}$ & $\begin{array}{c}1.067 * * \\
(0.475)\end{array}$ \\
\hline StockTurnover & $\begin{array}{c}-0.200^{* * *} \\
(0.042)\end{array}$ & $\begin{array}{c}0.242^{* * *} \\
(0.038)\end{array}$ & $\begin{array}{c}0.021 \\
(0.031)\end{array}$ & $\begin{array}{c}0.197^{* * * *} \\
(0.034)\end{array}$ \\
\hline Constant & $\begin{array}{c}6.015^{* * *} \\
(2.022)\end{array}$ & $\begin{array}{c}-6.302^{* * *} \\
(1.752)\end{array}$ & $\begin{array}{l}-0.827 \\
(0.903)\end{array}$ & $\begin{array}{c}-7.733^{* * *} \\
(1.153)\end{array}$ \\
\hline Year Dummies & $\mathrm{Y}$ & $\mathrm{Y}$ & $\mathrm{Y}$ & $\mathrm{Y}$ \\
\hline Observations & 7,871 & 7,871 & 6,250 & 6,250 \\
\hline Prob $>$ Chi $^{2}$ & 0.000 & 0.000 & 0.000 & 0.000 \\
\hline log likelihood & -1244 & -1244 & -1100 & -1100 \\
\hline
\end{tabular}


Appendix 1, Panel D: Alternative Specification for Bivariate Probit Model Estimation - Alternative Clustering Standard Errors.

This table reports re-estimation results of the bivariate probit model while clustering standard errors at different levels. Columns (1)-(4) and Columns (5)-(8) cluster standard errors at the firm- and CEO-firm pair level. Fraud incidence and detection regression specifications are identical to those in Table V. Control variables are not reported. All regressions include year dummies. Coefficients marked with *, ** and ${ }^{* * *}$ are significant at $10 \%, 5 \%, 1 \%$, respectively.

\begin{tabular}{|c|c|c|c|c|c|c|c|c|}
\hline & Fraud & Detect|Fraud & Fraud & Detect|Fraud & Fraud & Detect|Fraud & Fraud & Detect|Fraud \\
\hline VARIABLES & (1) & (2) & (3) & (4) & (5) & (6) & (7) & (8) \\
\hline \multirow[t]{2}{*}{ FTA } & $1.065 * * *$ & $-0.992 * * *$ & & & $1.065^{* * *}$ & $-0.992 * * *$ & & \\
\hline & $(0.354)$ & $(0.322)$ & & & $(0.353)$ & $(0.323)$ & & \\
\hline \multirow[t]{2}{*}{ FDA } & & & $1.223^{* *}$ & $-0.996 *$ & & & $1.223^{* *}$ & $-0.996 *$ \\
\hline & & & $(0.572)$ & $(0.528)$ & & & $(0.576)$ & $(0.531)$ \\
\hline Year Dummies & $\mathrm{Y}$ & $\mathrm{Y}$ & $\mathrm{Y}$ & $\mathrm{Y}$ & $\mathrm{Y}$ & $\mathrm{Y}$ & $\mathrm{Y}$ & $\mathrm{Y}$ \\
\hline Cluster by Firms & $\mathrm{Y}$ & $\mathrm{Y}$ & $\mathrm{Y}$ & $\mathrm{Y}$ & $\mathrm{N}$ & $\mathrm{N}$ & $\mathrm{N}$ & $\mathrm{N}$ \\
\hline \multicolumn{9}{|l|}{ Cluster by } \\
\hline CEO-Firm Pair & $\mathrm{N}$ & $\mathrm{N}$ & $\mathrm{N}$ & $\mathrm{N}$ & $\mathrm{Y}$ & $\mathrm{Y}$ & $\mathrm{Y}$ & $\mathrm{Y}$ \\
\hline Observations & 7,871 & 7,871 & 6,250 & 6,250 & 7,871 & 7,871 & 6,250 & 6,250 \\
\hline Prob $>\mathrm{Chi}^{2}$ & 0.000 & 0.000 & 0.000 & 0.000 & 0.000 & 0.000 & 0.000 & 0.000 \\
\hline log likelihood & -1253 & -1253 & -1101 & -1101 & -1253 & -1253 & -1101 & -1101 \\
\hline
\end{tabular}


Appendix 2: Abnormal Measures of Appointment-based CEO Connectedness and Corporate Fraud.

This table re-estimates Tables V, VII, VIII, and IX using abnormal measures of appointment-based CEO connectedness. AFTA, the abnormal fraction of top four non-CEO executives appointed during the current CEO's tenure, is the residual of the regression in Column (1) of Panel A. AFDA, the abnormal fraction of directors appointed during the current CEO's tenure the residual of the regression in Column (2) of Panel A AFTA+AFDA is the sum of AFTA and AFDA divided by 2 . The unreported control variables in Panels B-E are the same as those in Tables V, VII, VIII, and IX, respectively. Definitions of all variables are provided in Table I. Robust standard errors reported in parentheses are clustered at the industry level in Panels B, D, and E, and at the firm level in Panel A and C. Coefficients marked with *, **, and *** are significant at $10 \%, 5 \%, 1 \%$, respectively.

Panel A: Regressions to Construct AFTA and AFDA.

\begin{tabular}{|c|c|c|}
\hline VARIABLES & $\begin{array}{c}\text { FTA } \\
(1)\end{array}$ & $\begin{array}{c}\text { FDA } \\
(2)\end{array}$ \\
\hline CEO Tenure & $0.051^{* * *}$ & $\begin{array}{c}0.065^{* * *} \\
(0.000)\end{array}$ \\
\hline CEO_Tenure $^{2}$ & $\begin{array}{c}-0.001^{* * *} \\
(0.000)\end{array}$ & $\begin{array}{c}-0.001 * * * \\
(0.000)\end{array}$ \\
\hline Outside & $\begin{array}{c}0.021 * * * \\
(0.006)\end{array}$ & $\begin{array}{c}0.016^{* * *} \\
(0.004)\end{array}$ \\
\hline Execsen & $\begin{array}{c}-0.054 * * * \\
(0.001)\end{array}$ & \\
\hline Dircsen & & $\begin{array}{c}-0.029 * * * \\
(0.000)\end{array}$ \\
\hline FTA $1 Y$ Exe & $-0.169 * * *$ & \\
\hline FTA_1Y_Dir & & $\begin{array}{c}-0.349 * * * \\
(0.008)\end{array}$ \\
\hline FTA_1Y_Unknown_Exe & $\begin{array}{c}0.553 * * * \\
(0.061)\end{array}$ & \\
\hline Unknown_Exe & $\begin{array}{c}0.253^{* * *} * \\
(0.020)\end{array}$ & \\
\hline Constant & $\begin{array}{c}0.579 * * * \\
(0.009)\end{array}$ & $\begin{array}{c}0.338 * * * \\
(0.006)\end{array}$ \\
\hline $\begin{array}{l}\text { Year FE } \\
\text { Observations } \\
\text { Adiusted R-sauared }\end{array}$ & $\begin{array}{c}\mathrm{Y} \\
21599 \\
0.24\end{array}$ & $\begin{array}{l}\mathrm{Y} \\
11,063 \\
076\end{array}$ \\
\hline
\end{tabular}
Adjusted R-squared

Panel B: Bivariate Probit Model Estimation of Corporate Fraud

VARIABLES

AFTA Fraud Detect|Fraud Fraud (5) Fraud Detect|Fra

AFDA $(0.400)$ $\frac{(2)}{-0.989 * * *}$ (4) (8)

AFTA+AFDA

Year Dummies Observations Prob> Chi ${ }^{2}$ log likelihood (0.364) Fraud (7)

Panel C: Forced CEO Turnover-Fraud Sensitivity

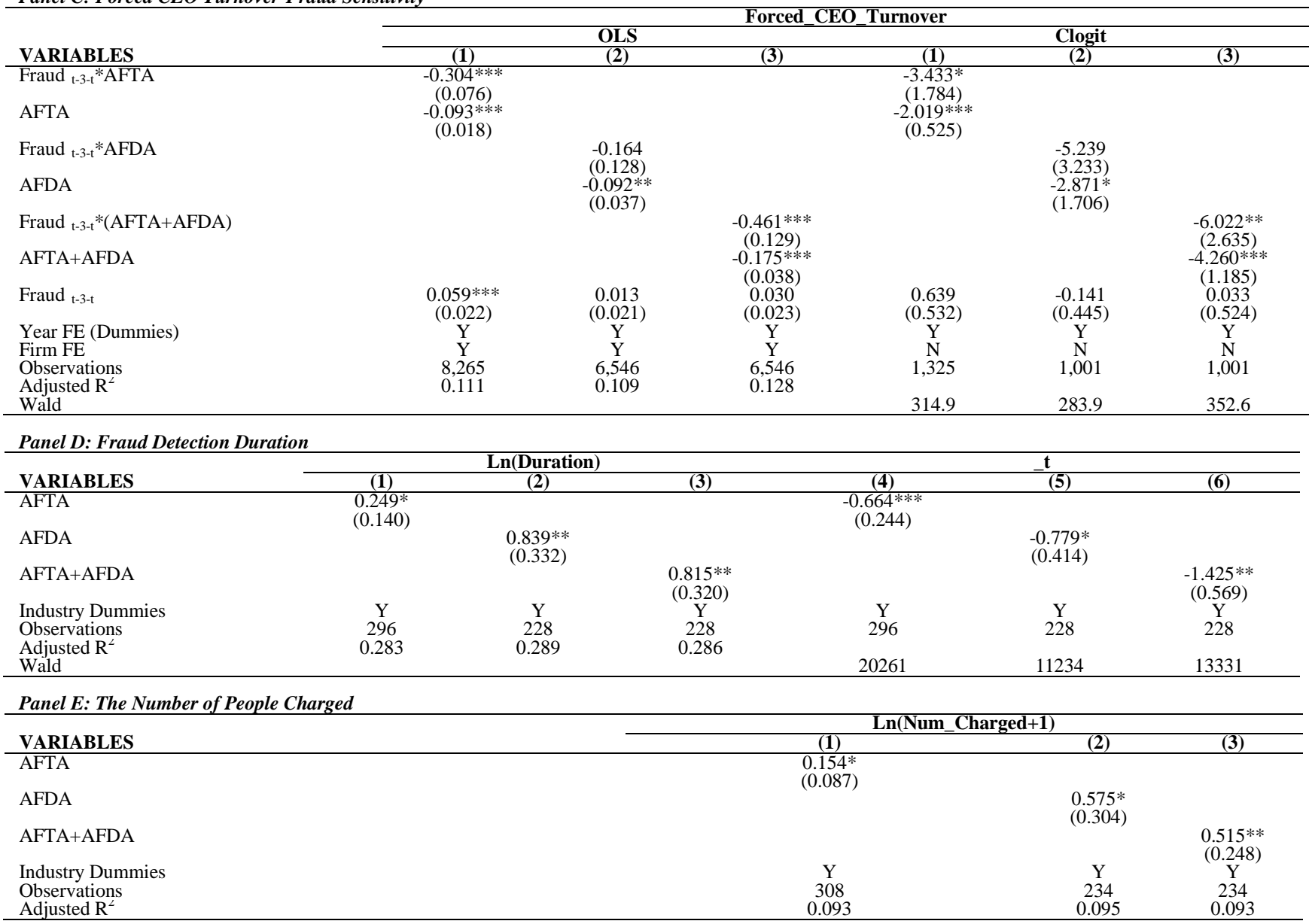


Appendix 3: Tenure Weighted Appointment-based CEO Connectedness Variables and Corporate Fraud.

This table re-estimates Tables V, VII, VIII, and IX using CEO connectedness measures weighted by the executives' tenure and directors' tenure. FTA_WT is the fraction of top four non-CEO executives appointed during the current CEO's tenure, weighted by the executives' tenure. AFTA_WT is the abnormal fraction of top four non-CEO executives appointed during the current CEO's tenure, weighted by the executives' tenure. FDA_WT is the fraction of directors appointed during the current CEO's tenure, weighted by the directors' tenure. AFDA_WT is abnormal fraction of directors appointed during the current CEO's tenure, weighted by the directors' tenure. The unreported control variables in Panels A-D are the same as those in Tables V, VII, VIII, and IX, respectively. Definitions of all variables are provided in Table I. Robust standard errors reported in parentheses are clustered at the industry level in Panels A, C and D and at the firm level in Panel B. Coefficients marked with *, **, and *** are significant at $10 \%, 5 \%, 1 \%$, respectively.

Panel A: Bivariate Probit Model Estimation of Corporate Fraud

\begin{tabular}{|c|c|c|c|c|c|c|c|c|}
\hline 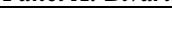 & Fraud & Detect|Fraud & Fraud & Detect|Fraud & Fraud & Detect|Fraud & Fraud & Detect|Fraud \\
\hline VARIABLES & (1) & (2) & (3) & (4) & (5) & (6) & (7) & (8) \\
\hline FTA_WT & $\begin{array}{c}0.554^{* * *} \\
(0.153)\end{array}$ & $\begin{array}{c}-1.061 * * * \\
(0.158)\end{array}$ & & & & & & \\
\hline AFTA_WT & & & $\begin{array}{c}0.418 * * \\
(0.170)\end{array}$ & $\begin{array}{c}-1.202 * * * \\
(0.227)\end{array}$ & & & & \\
\hline FDA_WT & & & & & $\begin{array}{c}1.299 * * * \\
(0.386)\end{array}$ & $\begin{array}{c}-1.117 * * * \\
(0.219)\end{array}$ & & \\
\hline AFDA_WT & & & & & & & $\begin{array}{c}1.054 * * \\
(0.523)\end{array}$ & $\begin{array}{c}-0.998 * * \\
(0.475)\end{array}$ \\
\hline Year Dummies & $\mathrm{Y}$ & Y & $\mathrm{Y}$ & Y & $\mathrm{Y}$ & Y & $\mathrm{Y}$ & $\mathrm{Y}$ \\
\hline Observations & 7,871 & 7,871 & 7,871 & 7,871 & 6,250 & 6,250 & 6,250 & 6,250 \\
\hline Prob $>\mathrm{Chi}^{2}$ & 0.000 & 0.000 & 0.000 & 0.000 & 0.000 & 0.000 & 0.000 & 0.000 \\
\hline log likelihood & -1253 & -1253 & -1254 & -1254 & -1106 & -1106 & -1102 & -1102 \\
\hline
\end{tabular}

Panel B: Forced CEO Turnover-Fraud Sensitivity

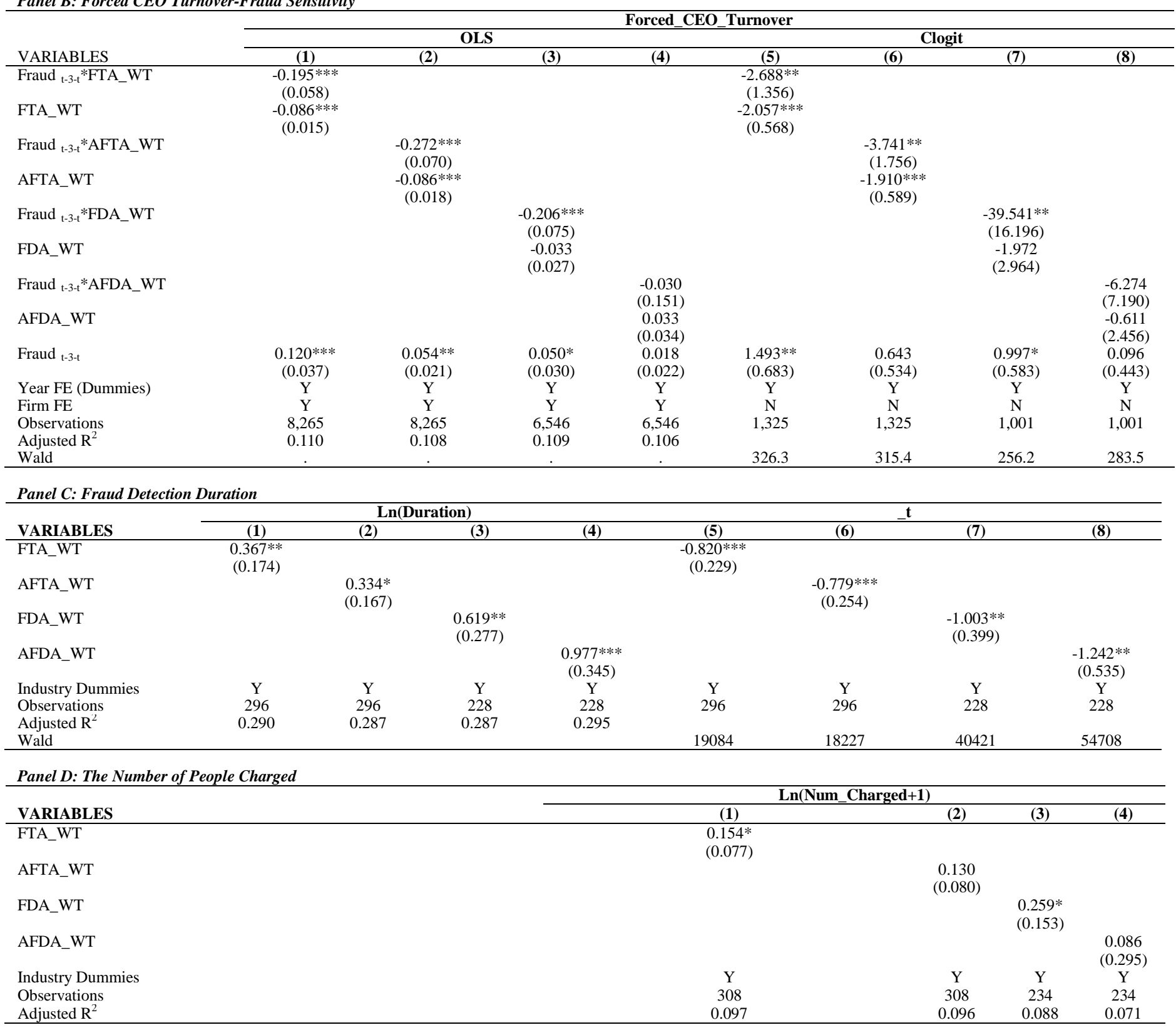


Appendix 4: Compensation Weighted Appointment-based CEO Connectedness Variables and Corporate Fraud.

This table re-estimates Tables V, VII, VIII, and IX using CEO connectedness measures weighted by the executives' compensation. FTA_WC is the fraction of top four non-CEO executives appointed during the current CEO's tenure, weighted by the executives' compensation. AFTA_WC is the abnormal fraction of top four non-CEO executives appointed during the current CEO's tenure, weighted by the executives' compensation. The unreported control variables in Panels A-D are the same as those in Tables V, VII, VIII, and IX, respectively. Definitions of all variables are provided in Table I. Robust standard errors reported in parentheses are clustered at the industry level in Panel A, C, and D and at the firm level in Panel B. Coefficients marked with *, **, and *** are significant at 10\%, 5\%, 1\%, respectively.

Panel A: Bivariate Probit Model Estimation of Corporate Fraud

\begin{tabular}{|c|c|c|c|c|}
\hline & Fraud & Detect|Fraud & Fraud & Detect|Fraud \\
\hline VARIABLES & (1) & (2) & (3) & (4) \\
\hline FTA_WC & $\begin{array}{c}1.102 * * * \\
(0.243)\end{array}$ & $\begin{array}{c}-0.990^{* * *} \\
(0.268)\end{array}$ & & \\
\hline AFTA_WC & & & $\begin{array}{c}1.221^{* * *} \\
(0.403)\end{array}$ & $\begin{array}{c}-1.059 * * * \\
(0.386)\end{array}$ \\
\hline Year Dummies & $\mathrm{Y}$ & $\mathrm{Y}$ & $\mathrm{Y}$ & $\mathrm{Y}$ \\
\hline Observations & 7,871 & 7,871 & 7,871 & 7,871 \\
\hline Prob $>\mathrm{Chi}^{2}$ & 0.000 & 0.000 & 0.000 & 0.000 \\
\hline log likelihood & -1253 & -1253 & -1254 & -1254 \\
\hline
\end{tabular}

Panel B: Forced CEO Turnover-Fraud Sensitivity

\begin{tabular}{|c|c|c|c|c|}
\hline \multirow[b]{3}{*}{ VARIABLES } & \multicolumn{4}{|c|}{ Forced_CEO_Turnover } \\
\hline & \multicolumn{2}{|c|}{ OLS } & \multicolumn{2}{|c|}{ Clogit } \\
\hline & (1) & (2) & (3) & (4) \\
\hline Fraud_t-3-t $* F T A \_W C$ & $\begin{array}{c}-0.208 * * * \\
(0.058)\end{array}$ & & $\begin{array}{c}-2.865^{*} \\
(1.501)\end{array}$ & \\
\hline FTA_WC & $\begin{array}{c}-0.090 * * * \\
(0.015)\end{array}$ & & $\begin{array}{c}-2.250 * * * \\
(0.528)\end{array}$ & \\
\hline Fraud_t-3-t $^{*}$ AFTA_WC & & $\begin{array}{c}-0.279 * * * \\
(0.073)\end{array}$ & & $\begin{array}{c}-3.417 * \\
(2.005)\end{array}$ \\
\hline AFTA_WC & & $\begin{array}{c}-0.092 * * * \\
(0.018)\end{array}$ & & $\begin{array}{c}-2.105^{* * *} \\
(0.530)\end{array}$ \\
\hline Fraud $_{-t-3-t}$ & $\begin{array}{c}0.134 * * * \\
(0.039)\end{array}$ & $\begin{array}{c}0.057 * * * \\
(0.021)\end{array}$ & $\begin{array}{c}1.611^{* *} \\
(0.748)\end{array}$ & $\begin{array}{c}0.683 \\
(0.548)\end{array}$ \\
\hline Year FE (Dummies) & $\mathrm{Y}$ & $\mathrm{Y}$ & $\mathrm{Y}$ & $\mathrm{Y}$ \\
\hline Firm FE & $\mathrm{Y}$ & $\mathrm{Y}$ & $\mathrm{N}$ & $\mathrm{N}$ \\
\hline Observations & 8,265 & 8,265 & 1,325 & 1,325 \\
\hline Adjusted $\mathrm{R}^{2}$ & 0.114 & 0.110 & & \\
\hline Wald & . & . & 323.5 & 312.4 \\
\hline \multicolumn{5}{|c|}{ Panel C: Fraud Detection Duration } \\
\hline & \multicolumn{2}{|c|}{ Ln(Duration) } & \multicolumn{2}{|c|}{$=$} \\
\hline VARIABLES & (1) & $(2)$ & (3) & (4) \\
\hline FTA_WC & $\begin{array}{l}1.066^{*} \\
(0.580)\end{array}$ & & $\begin{array}{c}-2.717 * * * \\
(0.769)\end{array}$ & \\
\hline AFTA_WC & & $\begin{array}{c}0.200 \\
(0.139)\end{array}$ & & $\begin{array}{c}-0.593 * * \\
(0.243)\end{array}$ \\
\hline Industry Dummies & $\mathrm{Y}$ & $\mathrm{Y}$ & $\mathrm{Y}$ & $\mathrm{Y}$ \\
\hline Observations & 296 & 296 & 296 & 296 \\
\hline Adjusted $\mathrm{R}^{2}$ & 0.285 & 0.282 & & \\
\hline Wald & & & 52927 & 54584 \\
\hline \multicolumn{5}{|c|}{ Panel D: The Number of People Charged } \\
\hline \multicolumn{5}{|c|}{ Ln(Num_Charged+1) } \\
\hline VARIABLES & & & (1) & $(2)$ \\
\hline FTA_WC & & & $\begin{array}{c}0.619 \\
(0.391)\end{array}$ & \\
\hline AFTA_WC & & & & $\begin{array}{c}0.129 \\
(0.095)\end{array}$ \\
\hline Industry Dummies & & & $\mathrm{Y}$ & $\mathrm{Y}$ \\
\hline Observations & & & 308 & 308 \\
\hline Adjusted $\mathrm{R}^{2}$ & & & 0.094 & 0.091 \\
\hline
\end{tabular}


Appendix 5: Appointment-based CEO Connectedness with Independent Directors and Non-independent Directors and Corporate Fraud.

This table re-estimates Tables V, VII, VIII, and IX using fractions of independent and non-independent directors appointed during the current CEO’s tenure. FIDA is the fraction of independent directors appointed during the current CEO's tenure. AFIDA is the abnormal FIDA. FNIDA is the fraction of non-independent directors appointed during the current CEO's tenure. AFNIDA is the abnormal FNIDA. The unreported control variables in Panels A-D are the same as those in Tables V, VII, VIII, and IX, respectively. Definitions of all variables are provided in Table I. Robust standard errors reported in parentheses are clustered at the industry level in Panels A, C and D and clustered at the firm level in Panel B. Coefficients marked with *, **, and *** are significant at $10 \%$, 5\%, $1 \%$, respectively.

Panel A: Bivariate Probit Model Estimation of Corporate Fraud

\begin{tabular}{|c|c|c|c|c|c|c|c|c|}
\hline VARIABLES & $\begin{array}{c}\text { Fraud } \\
\text { (1) }\end{array}$ & $\begin{array}{c}\text { Detect|Fraud } \\
(2)\end{array}$ & $\begin{array}{c}\text { Fraud } \\
\text { (3) }\end{array}$ & $\begin{array}{c}\text { Detect|Fraud } \\
\text { (4) }\end{array}$ & $\begin{array}{c}\text { Fraud } \\
\text { (5) }\end{array}$ & $\begin{array}{c}\text { Detect|Fraud } \\
(6)\end{array}$ & $\begin{array}{c}\text { Fraud } \\
\text { (7) }\end{array}$ & $\begin{array}{c}\text { Detect|Fraud } \\
\text { (8) }\end{array}$ \\
\hline FIDA & $\begin{array}{c}0.687 \\
(0.426)\end{array}$ & $\begin{array}{l}-0.496 \\
(0.329)\end{array}$ & & & & & & \\
\hline AFIDA & & & $\begin{array}{c}0.982 * * \\
(0.389)\end{array}$ & $\begin{array}{c}-0.799 * * \\
(0.374)\end{array}$ & & & & \\
\hline FNIDA & & & & & $\begin{array}{c}1.190 * * \\
(0.524)\end{array}$ & $\begin{array}{c}-1.055^{* *} \\
(0.496)\end{array}$ & & \\
\hline AFNIDA & & & & & & & $\begin{array}{c}1.246 * * \\
(0.608)\end{array}$ & $\begin{array}{l}-1.097^{*} \\
(0.589)\end{array}$ \\
\hline Year Dummies & $\mathrm{Y}$ & $\mathrm{Y}$ & $\mathrm{Y}$ & $\mathrm{Y}$ & $\mathrm{Y}$ & $\mathrm{Y}$ & $\mathrm{Y}$ & $\mathrm{Y}$ \\
\hline Observations & 6,237 & 6,237 & 6,237 & 6,237 & 6,246 & 6,246 & 6,246 & 6,246 \\
\hline Prob $>$ Chi $^{2}$ & 0.000 & 0.000 & 0.000 & 0.000 & 0.000 & 0.000 & 0.000 & 0.000 \\
\hline log likelihood & -1102 & -1102 & -1107 & -1107 & -1101 & -1101 & -1102 & -1102 \\
\hline
\end{tabular}

\begin{tabular}{|c|c|c|c|c|c|c|c|c|}
\hline \multirow[b]{3}{*}{ VARIABLES } & \multicolumn{8}{|c|}{ Forced_CEO_Turnover } \\
\hline & \multicolumn{4}{|c|}{ OLS } & \multicolumn{4}{|c|}{ Clogit } \\
\hline & (1) & (2) & (3) & (4) & (5) & (6) & (7) & (8) \\
\hline Fraud $_{\mathrm{t}-3-\mathrm{t}} *$ FIDA & $\begin{array}{c}-0.134 * * * \\
(0.049)\end{array}$ & & & & $\begin{array}{c}-0.791 \\
(3.054)\end{array}$ & & & \\
\hline FIDA & $\begin{array}{c}-0.091 * * * \\
(0.020)\end{array}$ & & & & $\begin{array}{c}-3.401 * * \\
(1.419)\end{array}$ & & & \\
\hline Fraud ${ }_{\mathrm{t}-3-\mathrm{t}} *$ AFIDA & & $\begin{array}{l}-0.120 \\
(0.102)\end{array}$ & & & & $\begin{array}{l}-1.392 \\
(3.110)\end{array}$ & & \\
\hline AFIDA & & $\begin{array}{c}-0.072^{* *} \\
(0.029)\end{array}$ & & & & $\begin{array}{l}-2.594^{*} \\
(1.373)\end{array}$ & & \\
\hline Fraud ${ }_{t-3-\mathrm{t}} *$ FNIDA & & & $\begin{array}{c}-0.090 * * \\
(0.043)\end{array}$ & & & & $\begin{array}{l}-3.067 \\
(2.223)\end{array}$ & \\
\hline FNIDA & & & $\begin{array}{l}-0.007 \\
(0.020)\end{array}$ & & & & $\begin{array}{c}0.336 \\
(1.293)\end{array}$ & \\
\hline Fraud ${ }_{\mathrm{t}-3-\mathrm{t}} *$ AFNIDA & & & & $\begin{array}{c}-0.040 \\
(0.076)\end{array}$ & & & & $\begin{array}{c}-4.463^{*} \\
(2.694)\end{array}$ \\
\hline AFNIDA & & & & $\begin{array}{c}-0.010 \\
(0.024)\end{array}$ & & & & $\begin{array}{c}0.337 \\
(1.197)\end{array}$ \\
\hline Fraud ${ }_{t-3-t}$ & $\begin{array}{c}0.068 * * \\
(0.033)\end{array}$ & $\begin{array}{c}0.018 \\
(0.019)\end{array}$ & $\begin{array}{c}0.038 \\
(0.025)\end{array}$ & $\begin{array}{c}0.021 \\
(0.020)\end{array}$ & $\begin{array}{c}0.299 \\
(0.437)\end{array}$ & $\begin{array}{c}0.170 \\
(0.450)\end{array}$ & $\begin{array}{c}0.510 \\
(0.448)\end{array}$ & $\begin{array}{c}0.327 \\
(0.410)\end{array}$ \\
\hline Year FE (Dummies) & $\mathrm{Y}$ & $\mathrm{Y}$ & $\mathrm{Y}$ & $\mathrm{Y}$ & $\mathrm{Y}$ & $\mathrm{Y}$ & $\mathrm{Y}$ & $\mathrm{Y}$ \\
\hline Firm FE & $\mathrm{Y}$ & $\mathrm{Y}$ & $\mathrm{Y}$ & $\mathrm{Y}$ & $\mathrm{N}$ & $\mathrm{N}$ & $\mathrm{N}$ & $\mathrm{N}$ \\
\hline Observations & 6,532 & 6,532 & 6,541 & 6,541 & 1,001 & 1,001 & 1,001 & 1,001 \\
\hline Adjusted R² & 0.117 & 0.109 & 0.107 & 0.106 & & & & \\
\hline Wald & . & . & . & . & 302.0 & 294.6 & 261.3 & 285.9 \\
\hline
\end{tabular}

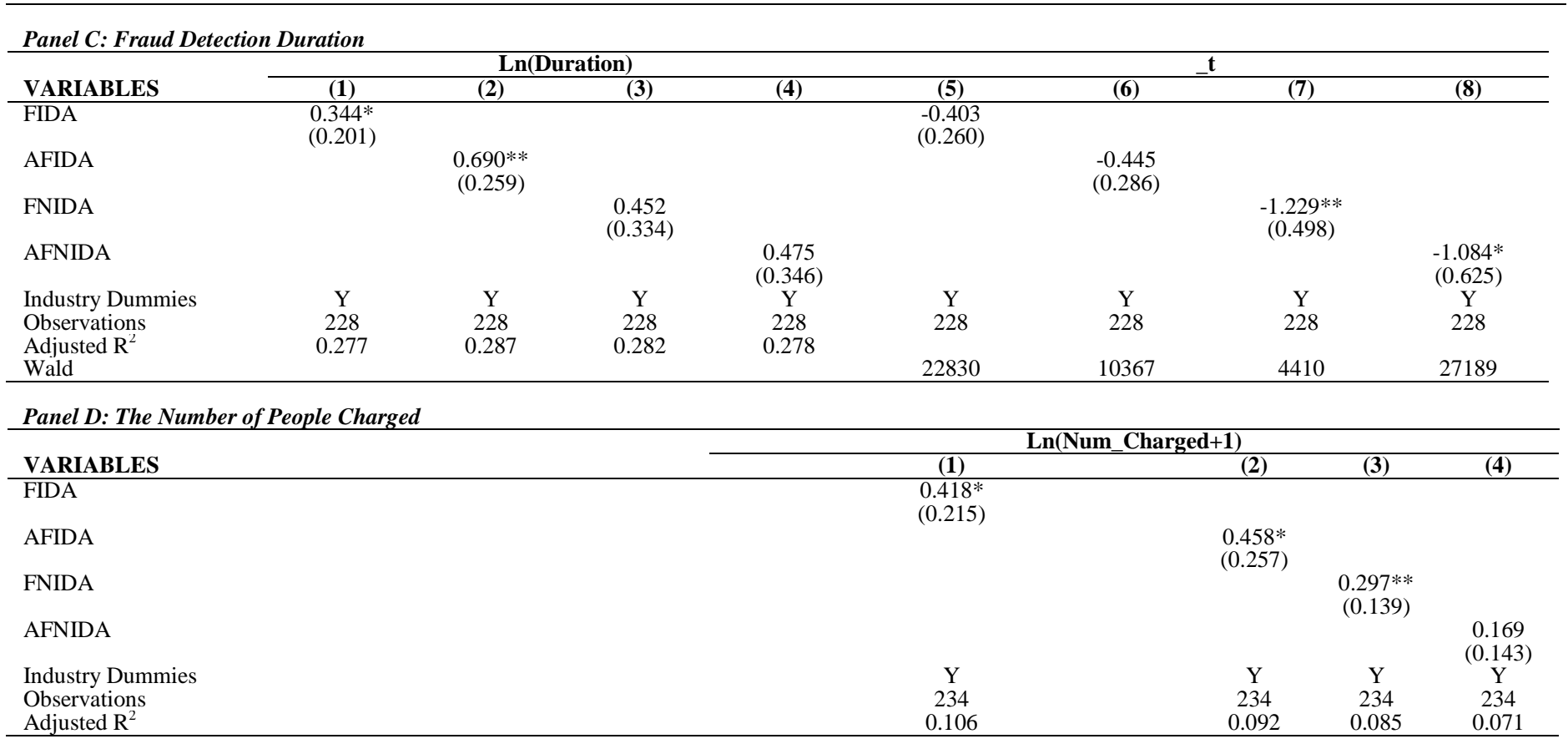


Appendix 6: Appointment-based CEO Connectedness and Corporate Fraud - Fraud Sample Including Fraud Cases in which the CEO is Not a Named Respondent.

This table re-estimates Tables V, VII, VIII, and IX based on the sample including both CEO-named and CEO-not-named fraud cases. The unreported control variables in Panels A-D are the same as those in Tables V, VII, VIII, and IX, respectively. Definitions of all variables are provided in Table I. Robust standard errors reported in parentheses are clustered at the industry level in Panels A, C, and D and at the firm level in Panel B. Coefficients marked with $* * *$, and $* * *$ are significant at $10 \%, 5 \%, 1 \%$, respectively.

Panel A: Bivariate Probit Model Estimation of Corporate Fraud

\begin{tabular}{|c|c|c|c|c|c|c|}
\hline VARIABLES & Fraud & Detect|Fraud & $\begin{array}{c}\text { Fraud } \\
\text { (3) }\end{array}$ & $\begin{array}{c}\text { Detect|Fraud } \\
4)\end{array}$ & $\begin{array}{c}\text { Fraud } \\
(5)\end{array}$ & $\begin{array}{c}\text { Detect|Fraud } \\
(6)\end{array}$ \\
\hline FTA & $\begin{array}{l}0.783^{*} \\
(0.473)\end{array}$ & $\begin{array}{c}-0.896^{* *} \\
(0.446)\end{array}$ & & & & \\
\hline FDA & & & $\begin{array}{c}0.622 * * * \\
(0.212)\end{array}$ & $\begin{array}{c}-1.085^{* * *} \\
(0.145)\end{array}$ & & \\
\hline FTA+FDA & & & & & $\begin{array}{c}1.428 * * * \\
(0.542)\end{array}$ & $\begin{array}{c}-1.411 * * * \\
(0.484)\end{array}$ \\
\hline Year Dummies & $\mathrm{Y}$ & $\mathrm{Y}$ & $\mathrm{Y}$ & $\mathrm{Y}$ & $\mathrm{Y}$ & $\mathrm{Y}$ \\
\hline Observations & 7,871 & 7,871 & 6,250 & 6,250 & 6,250 & 6,250 \\
\hline Prob $>\mathrm{Chi}^{2}$ & 0.000 & 0.000 & 0.000 & 0.000 & 0.000 & 0.000 \\
\hline log likelihood & -1475 & -1475 & -1296 & -1296 & -1297 & -1297 \\
\hline
\end{tabular}

Panel B: Forced CEO Turnover-Fraud Sensitivity

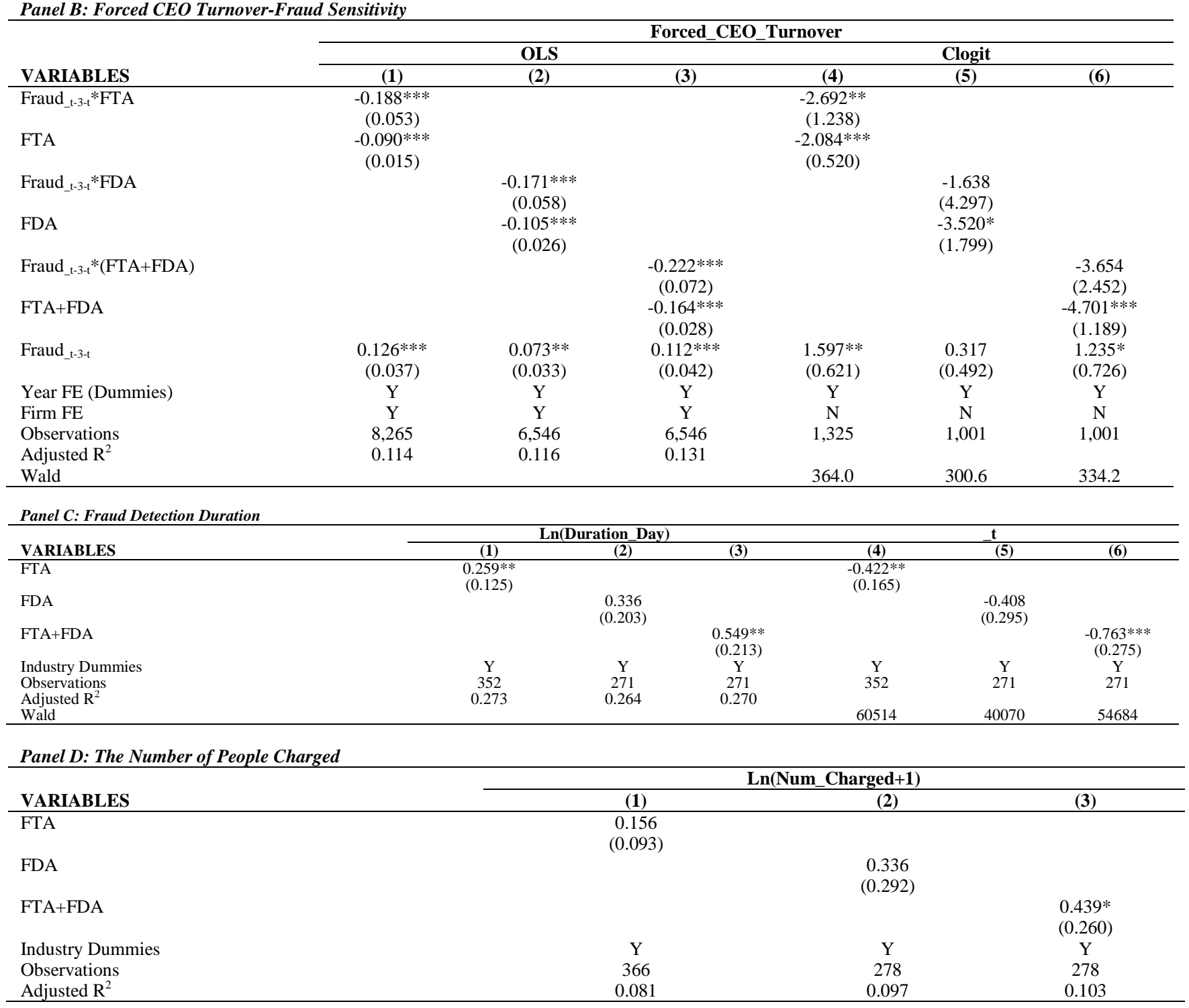


Appendix 7: Pre-existing Network Ties between the CEO and Top Executives and Corporate Fraud.

This table re-estimates Tables V, VII, VIII, and IX using pre-existing network ties between the CEO and top 4 non-CEO executives as the measure of CEO connectedness. Exe_Tie_Emp is the total number of pre-existing network ties a CEO has with top 4 non-CEO executives through past employment (either working as an employee or serving on the board) divided by four. Exe Tie Edu is the total number of pre-existing network ties a CEO has with top 4 non-CEO executives through past educational institutions divided by four. Exe Tie_Soc is the total number of pre-existing network ties a CEO has with top 4 non-CEO executives through past membership to social and professional organizations divided four. Exe Tie is the total number of pre-existing network ties a CEO has with top 4 non-CEO executives through past employment, educational institutions, and past membership to social and professional organizations divided by four. Only network ties established during overlapping years are included. The unreported control variables in Panels A-D are the same as those in Tables V, VII, VIII, and XI, respectively. Definitions of all variables are provided in Table I. Robust standard errors reported in parentheses are clustered at the same as those in Tables V, VII, VIII, and XI, respectively. Definitions of all variables are provided in Table I. Robust standard errors reported in parent
industry level in Panels A, C and D and at the firm level in Panel B. Coefficients marked with *, **, and *** are significant at 10\%, 5\%, 1\%, respectively.

\begin{tabular}{|c|c|c|c|c|c|c|c|c|}
\hline - & Fraud & Detect|Fraud & Fraud & Detect|Fraud & Fraud & Detect|Fraud & Fraud & Detect|Fraud \\
\hline VARIABLES & (1) & (2) & (3) & (4) & (5) & (6) & $(7)$ & (8) \\
\hline Exe_Tie & $\begin{array}{c}-0.108 \\
(0.098)\end{array}$ & $\begin{array}{c}0.022 \\
(0.098)\end{array}$ & & & & & & \\
\hline Exe_Tie_Emp & & & $\begin{array}{l}-0.142 \\
(0.099)\end{array}$ & $\begin{array}{c}0.041 \\
(0.106)\end{array}$ & & & & \\
\hline Exe Tie Edu & & & & & $\begin{array}{c}-0.522 \\
(0.715)\end{array}$ & $\begin{array}{c}3.172 * * * \\
(0.692)\end{array}$ & & \\
\hline Exe Tie Soc & & & & & & & $\begin{array}{c}5.888 \\
(4.385)\end{array}$ & $\begin{array}{l}-3.749 \\
(2.723)\end{array}$ \\
\hline Pct_Known_Exe_Tie & $\begin{array}{c}-0.803^{* * *} \\
(0.247)\end{array}$ & $\begin{array}{c}0.187 \\
(0.285)\end{array}$ & $\begin{array}{c}-0.771^{* * *} \\
(0.246)\end{array}$ & $\begin{array}{c}0.171 \\
(0.296)\end{array}$ & $\begin{array}{c}-0.693 * * * \\
(0.240)\end{array}$ & $\begin{array}{c}-0.006 \\
(0.241)\end{array}$ & $\begin{array}{c}-0.653 \\
(0.418)\end{array}$ & $\begin{array}{c}0.378 \\
(0.385)\end{array}$ \\
\hline Year Dummies & $\mathrm{Y}$ & $\mathrm{Y}$ & Y & $\mathrm{Y}$ & Y & $\mathrm{Y}$ & $\mathrm{Y}$ & $\mathrm{Y}$ \\
\hline Observations & 7,871 & 7,871 & 7,871 & 7,871 & 7,871 & 7,871 & 7,871 & 7,871 \\
\hline Prob $>\mathrm{Chi}^{2}$ & 0.000 & 0.000 & 0.000 & 0.000 & 0.000 & 0.000 & 0.000 & 0.000 \\
\hline log likelihood & -1259 & -1259 & -1259 & -1259 & -1258 & -1258 & -1254 & -1254 \\
\hline
\end{tabular}

Panel B: Forced CEO Turnover-Fraud Sensitivity

\begin{tabular}{|c|c|c|c|c|c|c|c|c|}
\hline \multirow[b]{3}{*}{ VARIABLES } & \multicolumn{8}{|c|}{ Forced_CEO_Turnover } \\
\hline & \multicolumn{4}{|c|}{ OLS } & \multicolumn{4}{|c|}{ Clogit } \\
\hline & (1) & (2) & (3) & (4) & (5) & (6) & (7) & (8) \\
\hline Fraud ${ }_{t-3-t}{ }^{*}$ Exe_Tie & $\begin{array}{c}0.060 \\
(0.040)\end{array}$ & & & & $\begin{array}{c}0.539 \\
(0.366)\end{array}$ & & & \\
\hline Exe Tie & $\begin{array}{l}-0.015 \\
(0.014)\end{array}$ & & & & $\begin{array}{c}0.020 \\
(0.498)\end{array}$ & & & \\
\hline Fraud t-3-t*Exe_Tie_Emp & & $\begin{array}{c}0.061 \\
(0.041)\end{array}$ & & & & $\begin{array}{c}0.560 \\
(0.375)\end{array}$ & & \\
\hline Exe_Tie_Emp & & $\begin{array}{l}-0.016 \\
(0.015)\end{array}$ & & & & $\begin{array}{l}-0.017 \\
(0.532)\end{array}$ & & \\
\hline Fraud ${ }_{t-3-\mathrm{t}} *$ Exe_Tie_Edu & & & $\begin{array}{r}-0.223 \\
(0.187)\end{array}$ & & & & $\begin{array}{l}-8.357 * \\
(4.707)\end{array}$ & \\
\hline Exe_Tie_Edu & & & $\begin{array}{l}-0.007 \\
(0.048)\end{array}$ & & & & $\begin{array}{c}(4 . / 07) \\
2.293 \\
(3.128)\end{array}$ & \\
\hline Fraud ${ }_{t-3-t} *$ Exe Tie Soc & & & & $\begin{array}{c}1.094 \\
(1.244)\end{array}$ & & & & $\begin{array}{l}527.749 \\
(0.000)\end{array}$ \\
\hline Exe Tie Soc & & & & $\begin{array}{c}0.021 \\
(0.047)\end{array}$ & & & & $\begin{array}{l}527.749 \\
(0.000)\end{array}$ \\
\hline Fraud $\mathrm{t}-3-\mathrm{t}$ & $\begin{array}{c}0.011 \\
(0.023)\end{array}$ & $\begin{array}{c}0.012 \\
(0.023)\end{array}$ & $\begin{array}{l}0.035^{*} \\
(0.020)\end{array}$ & $\begin{array}{c}0.030 \\
(0.019)\end{array}$ & $\begin{array}{c}0.364 \\
(0.523)\end{array}$ & $\begin{array}{c}0.370 \\
(0.516)\end{array}$ & $\begin{array}{c}0.757 \\
(0.486)\end{array}$ & $\begin{array}{c}0.602 \\
(0.464)\end{array}$ \\
\hline Pct Known Exe Tie & $\begin{array}{r}0.009 \\
(0.022)\end{array}$ & $\begin{array}{c}0.010 \\
(0.022)\end{array}$ & $\begin{array}{c}0.006 \\
(0.021)\end{array}$ & $\begin{array}{c}0.006 \\
(0.021)\end{array}$ & $\begin{array}{c}0.644 \\
(0.690)\end{array}$ & $\begin{array}{c}0.652 \\
(0.692)\end{array}$ & $\begin{array}{c}0.733 \\
(0.659)\end{array}$ & $\begin{array}{c}0.727 \\
(0.661)\end{array}$ \\
\hline Year FE (Dummies) & $\mathrm{Y}$ & $\mathrm{Y}$ & $\mathrm{Y}$ & $\mathrm{Y}$ & $\mathrm{Y}$ & $\mathrm{Y}$ & $\mathrm{Y}$ & $\mathrm{Y}$ \\
\hline $\begin{array}{l}\text { Firm FE } \\
\text { Observations }\end{array}$ & 8,265 & 8,265 & 8,265 & 8,265 & 1,325 & 1,325 & 1,325 & 1,325 \\
\hline $\begin{array}{l}\text { Adjusted } \mathrm{R}^{2} \\
\text { Wald }\end{array}$ & 0.090 & 0.090 & 0.089 & 0.090 & 298.4 & 298.4 & 284.0 & 121.7 \\
\hline \multicolumn{9}{|c|}{ Panel C: Fraud Detection Duration } \\
\hline & \multicolumn{4}{|c|}{ Ln(Duration) } & \multicolumn{4}{|c|}{$\mathbf{t}$} \\
\hline VARIABLES & (1) & (2) & (3) & (4) & (5) & (6) & (7) & (8) \\
\hline Exe_Tie & $\begin{array}{l}-0.159 \\
(0.113)\end{array}$ & & & & $\begin{array}{c}0.112 \\
(0.129)\end{array}$ & & & \\
\hline Exe Tie Emp & & $\begin{array}{l}-0.148 \\
(0.113)\end{array}$ & & & & $\begin{array}{c}0.114 \\
(0.137)\end{array}$ & & \\
\hline Exe Tie Edu & & & $\begin{array}{l}-0.704 \\
(1.166)\end{array}$ & & & & $\begin{array}{l}-0.247 \\
(1.111)\end{array}$ & \\
\hline Exe_Tie_Soc & & & & $\begin{array}{l}-4.533 \\
(6.572)\end{array}$ & & & & $\begin{array}{c}6.649 \\
(8.180)\end{array}$ \\
\hline Pct Known Exe Tie & $\begin{array}{c}0.347 * * * \\
(0.109)\end{array}$ & $\begin{array}{c}0.343 * * * \\
(0.109)\end{array}$ & $\begin{array}{c}0.325^{* * * *} \\
(0.108)\end{array}$ & $\begin{array}{c}0.321 * * * \\
(0.116)\end{array}$ & $\begin{array}{c}-0.565 * * * \\
(0.182)\end{array}$ & $\begin{array}{c}-0.565 * * * \\
(0.182)\end{array}$ & $\begin{array}{c}-0.544 * * * \\
(0.184)\end{array}$ & $\begin{array}{c}-0.551 * * * \\
(0.187)\end{array}$ \\
\hline Industry Dummies & & $\mathrm{Y}$ & & $\mathrm{Y}$ & $\mathrm{Y}$ & $\mathrm{Y}$ & $\mathrm{Y}$ & $\mathrm{Y}$ \\
\hline Observations & 296 & 296 & 296 & 296 & 296 & 296 & 296 & 296 \\
\hline $\begin{array}{l}\text { Adjusted } \mathrm{R}^{<} \\
\text {Wald }\end{array}$ & 0.290 & 0.290 & 0.286 & 0.288 & 20836 & 20715 & 44146 & 30157 \\
\hline \multicolumn{9}{|c|}{ Panel D: The Number of People Charged } \\
\hline \multicolumn{9}{|c|}{ Ln(Num_Charged+1) } \\
\hline VARIABLES & & & (1) & & (2) & & & (4) \\
\hline Exe Tie & & & $\begin{array}{c}0.021 \\
(0.065)\end{array}$ & & & & & \\
\hline Exe_Tie_Emp & & & & & $\begin{array}{c}0.017 \\
(0.067)\end{array}$ & & & \\
\hline Exe Tie Edu & & & & & & & & \\
\hline Exe_Tie_Soc & & & & & & & & 0.729 \\
\hline Pct_Known_Exe_Tie & & & 0.102 & & 0.103 & & & 0.107 \\
\hline & & & $(0.158)$ & & $(0.158)$ & & & $(0.152)$ \\
\hline Industry Dummies & & & $\mathrm{Y}$ & & $\mathrm{Y}$ & & & $\mathrm{Y}$ \\
\hline Observations & & & 308 & & 308 & & & 308 \\
\hline Adjusted $\mathrm{R}^{2}$ & & & 0.089 & & 0.089 & & & 0.089 \\
\hline
\end{tabular}


Appendix 8: Pre-existing Network Ties between the CEO and Directors and Corporate Fraud.

This table re-estimates Tables V, VII, VIII, and IX using pre-existing network ties between the CEO and directors as the measure of CEO connectedness. Dir_Tie_Emp is the total number of pre-existing network ties a CEO has with directors through past employment (either working as an employee or serving on the board) divided by the number of directors on the board. Dir Tie Edu is the total number of pre-existing network ties a CEO has with directors through past educational institutions divided by the number of directors on the board. Dir-Tie_Soc is the total number of pre-existing network ties a CEO has with directors through past membership to social and professional organizations divided by the number of directors on the board. Dir Tie is the total number of pre-existing network ties a CEO has with directors through past employment, educational institutions, and past membership to social and professional organizations divided by the number of directors on the board. Only network ties established during overlapping institutions, and past membership to social and professional organizations divided by the number of directors on the board. Only network ties established during overlapping years are included. The unreported control variables in Panels A-D are the same as those in Tables V, VII, VIII, and XI, respectively. Definitions of all variables are provided in
Table I. Robust standard errors reported in parentheses are clustered at the industry level in Panels A, C and D and at the firm level in Panel B. Coefficients marked with *, **,

Panel A: Bivariate Probit Model Estimation of Corporate Fraud

\begin{tabular}{|c|c|c|c|c|c|c|c|c|}
\hline ( & Fraud & Detect|Fraud & Fraud & Detect|Fraud & Fraud & Detect|Fraud & Fraud & Detect|Fraud \\
\hline VARIABLES & (1) & (2) & (3) & (4) & (5) & (6) & (7) & (8) \\
\hline Dir Tie & $\begin{array}{r}-0.413 \\
(0.975)\end{array}$ & $\begin{array}{c}0.215 \\
(0.813)\end{array}$ & & & & & & \\
\hline Dir Tie Emp & & & $\begin{array}{c}-0.635 * * * \\
(0149)\end{array}$ & 0.111 & & & & \\
\hline Dir_Tie_Edu & & & & & $\begin{array}{c}-2.484 * * * \\
(0.792)\end{array}$ & $\begin{array}{c}0.764 \\
(1.171)\end{array}$ & & \\
\hline Dir_Tie_Soc & & & & & & & $\begin{array}{c}2.641^{* * * *} \\
(0.803)\end{array}$ & $\begin{array}{l}-0.966 \\
(0.768)\end{array}$ \\
\hline Pct_Known_Dir_Tie & $\begin{array}{l}8.761 * \\
(4.626)\end{array}$ & $\begin{array}{l}-7.931 \\
(4.972)\end{array}$ & $\begin{array}{l}-0.991 \\
(0.917)\end{array}$ & $\begin{array}{c}-6.342 * * * \\
(1.020)\end{array}$ & $\begin{array}{c}0.009 \\
(0.965)\end{array}$ & $\begin{array}{c}-6.243 * * * \\
(1.027)\end{array}$ & $\begin{array}{c}9.594 * * * \\
(2.608)\end{array}$ & $\begin{array}{c}-9.162 * * * \\
(2.374)\end{array}$ \\
\hline Year Dummies & $\mathrm{Y}$ & $\mathrm{Y}$ & $\mathrm{Y}$ & $\mathrm{Y}$ & $\mathrm{Y}$ & $\mathrm{Y}$ & $\mathrm{Y}$ & $\mathrm{Y}$ \\
\hline Observations & 7,871 & 7,871 & 7,871 & 7,871 & 7,871 & 7,871 & 7,871 & 7,871 \\
\hline Prob > Chi ${ }^{2}$ & 0.000 & 0.000 & 0.000 & 0.000 & 0.000 & 0.000 & 0.000 & 0.000 \\
\hline log likelihood & -1252 & -1252 & -1252 & -1252 & -1258 & -1258 & -1242 & -1242 \\
\hline
\end{tabular}

Panel B: Forced CEO Turnover-Fraud Sensitivity

\begin{tabular}{|c|c|c|c|c|c|c|c|c|}
\hline \multirow[b]{3}{*}{ VARIABLES } & \multicolumn{8}{|c|}{ Forced_CEO_Turnover } \\
\hline & \multicolumn{4}{|c|}{ OLS } & \multicolumn{4}{|c|}{ Clogit } \\
\hline & (1) & (2) & (3) & (4) & (5) & (6) & (7) & (8) \\
\hline Fraud t-3-t ${ }^{*}$ Dir_Tie & 0.006 & & & & -1.304 & & & \\
\hline Dir Tie & $\begin{array}{l}-0.033 \\
(0.021)\end{array}$ & & & & $\begin{array}{l}-0.786 \\
(0.794)\end{array}$ & & & \\
\hline Fraud $_{\mathrm{t}-3 \mathrm{-t}} *$ Dir Tie Emp & & $\begin{array}{c}0.006 \\
(0.071)\end{array}$ & & & & $\begin{array}{l}-0.986 \\
(1.268)\end{array}$ & & \\
\hline Dir_Tie_Emp & & $\begin{array}{l}-0.009 \\
(0.020)\end{array}$ & & & & -0.613 & & \\
\hline Fraud ${ }_{\mathrm{t}-3-\mathrm{t}} *$ Dir Tie Edu & & & $\begin{array}{l}-0.211 \\
(0.585)\end{array}$ & & & & $\begin{array}{c}-12.932 * \\
(6.993)\end{array}$ & \\
\hline Dir_Tie_Edu & & & $-0.289 * * *$ & & & & -1.699 & \\
\hline Fraud t-3-t*Dir_Tie_Soc & & & & 0.144 & & & & -3.495 \\
\hline Dir_Tie_Soc & & & & $\begin{array}{r}(0.286) \\
-0.285 * * \\
(0.138)\end{array}$ & & & & $\begin{array}{l}(5.183) \\
-3.625 \\
(2.820)\end{array}$ \\
\hline Fraud $t-3-t$ & $\begin{array}{c}0.028 \\
(0.049)\end{array}$ & $\begin{array}{c}0.029 \\
(0.036)\end{array}$ & $\begin{array}{c}0.052 \\
(0.062)\end{array}$ & $\begin{array}{c}0.016 \\
(0.037)\end{array}$ & $\begin{array}{l}1.410^{*} \\
(0.846)\end{array}$ & $\begin{array}{c}0.999 \\
(0.694)\end{array}$ & $\begin{array}{l}1.964 * * \\
(0.870)\end{array}$ & $\begin{array}{r}0.985 \\
(0.732)\end{array}$ \\
\hline Pct_Known_Dir_Tie & $\begin{array}{c}0.021 \\
(0.041)\end{array}$ & $\begin{array}{l}-0.001 \\
(0.040)\end{array}$ & $\begin{array}{c}0.025 \\
(0.037)\end{array}$ & $\begin{array}{c}0.022 \\
(0.038)\end{array}$ & $\begin{array}{c}0.791 \\
(0.996)\end{array}$ & $\begin{array}{l}0.498 \\
(0.962)\end{array}$ & $\begin{array}{c}0.355 \\
(0.858)\end{array}$ & 0.548 \\
\hline Year FE (Dummies) & $\mathrm{Y}$ & $\mathrm{Y}$ & $\mathrm{Y}$ & $\mathrm{Y}$ & $\mathrm{Y}$ & $\mathrm{Y}$ & $\mathrm{Y}$ & $\mathrm{Y}$ \\
\hline Firm FE & $\mathrm{Y}$ & $\mathrm{Y}$ & $\mathrm{Y}$ & $\mathrm{Y}$ & $\mathrm{N}$ & $\mathrm{N}$ & $\mathrm{N}$ & $\mathrm{N}$ \\
\hline Observations & 8,265 & 8,265 & 8,265 & 8,265 & 1,325 & 1,325 & 1,325 & 1,325 \\
\hline $\begin{array}{l}\text { Adjusted R² } \\
\text { Wald }\end{array}$ & 0.090 & 0.089 & 0.092 & 0.091 & 314.4 & 317.4 & 312.9 & 318.0 \\
\hline \multicolumn{9}{|c|}{ Panel C: Fraud Detection Duration } \\
\hline & & $\mathbf{L n}$ & tion) & & & & & \\
\hline VARIABLES & (1) & (2) & (3) & (4) & (5) & (6) & (7) & (8) \\
\hline Dir Tie & $\begin{array}{c}0.234 \\
(0.294)\end{array}$ & & & & $\begin{array}{l}-0.914 * \\
(0.507)\end{array}$ & & & \\
\hline Dir_Tie_Emp & & $\begin{array}{c}0.253 \\
(0.295)\end{array}$ & & & & $\begin{array}{l}-0.998 * \\
(0.561)\end{array}$ & & \\
\hline Dir_Tie_Edu & & & $\begin{array}{l}1.831 \\
(1.858)\end{array}$ & & & & $\begin{array}{c}-4.494 * * \\
(1.969)\end{array}$ & \\
\hline Dir_Tie_Soc & & & & $\begin{array}{l}-0.474 \\
(1.356)\end{array}$ & & & & $\begin{array}{c}0.260 \\
(1.523)\end{array}$ \\
\hline Pct_Known_Dir_Tie & $\begin{array}{l}-0.072 \\
(0.240)\end{array}$ & $\begin{array}{l}-0.021 \\
(0.178)\end{array}$ & $\begin{array}{l}-0.148 \\
(0.313)\end{array}$ & $\begin{array}{c}0.138 \\
(0.203)\end{array}$ & $\begin{array}{c}0.400 \\
(0.435)\end{array}$ & $\begin{array}{c}0.210 \\
(0.328)\end{array}$ & $\begin{array}{c}0.355 \\
(0.406)\end{array}$ & $\begin{array}{l}-0.228 \\
(0.281)\end{array}$ \\
\hline Industry Dummies & $\mathrm{Y}$ & $\mathrm{Y}$ & $\mathrm{Y}$ & $\mathrm{Y}$ & $\mathrm{Y}$ & $\mathrm{Y}$ & $\mathrm{Y}$ & $\mathrm{Y}$ \\
\hline Observations & 296 & 296 & 296 & 296 & 296 & 296 & 296 & 296 \\
\hline $\begin{array}{l}\text { Adjusted R } \\
\text { Wald }\end{array}$ & 0.280 & 0.280 & 0.282 & 0.277 & 8885 & 25789 & 18075 & 46829 \\
\hline
\end{tabular}

Panel D: The Number of People Charged

\begin{tabular}{|c|c|c|c|c|}
\hline \multirow[b]{2}{*}{ VARIABLES } & \multicolumn{4}{|c|}{ Ln(Num_Charged+1) } \\
\hline & (1) & (2) & (3) & (4) \\
\hline Dir_Tie & $\begin{array}{c}-0.027 \\
(0.165)\end{array}$ & & & \\
\hline Dir Tie Emp & & $\begin{array}{c}0.043 \\
(0.192)\end{array}$ & & \\
\hline Dir Tie Edu & & & $\begin{array}{l}-1.266 \\
(0.856)\end{array}$ & \\
\hline Dir_Tie_Soc & & & & $\begin{array}{c}-0.878 \\
(0.592)\end{array}$ \\
\hline Pct_Known_Dir_Tie & $\begin{array}{c}-0.035 \\
(0.169)\end{array}$ & $\begin{array}{l}-0.070 \\
(0.151)\end{array}$ & $\begin{array}{c}0.086 \\
(0.134)\end{array}$ & $\begin{array}{c}0.047 \\
(0.129)\end{array}$ \\
\hline Industry Dummies & $\mathrm{Y}$ & $\mathrm{Y}$ & $\mathrm{Y}$ & Y \\
\hline Observations & 308 & 308 & 308 & 308 \\
\hline Adjusted R ${ }^{<}$ & 0.087 & 0.087 & 0.094 & 0.092 \\
\hline
\end{tabular}


Appendix 9: CEO Power and Corporate Fraud.

This table re-estimates Tables V, VII, VIII, and IX using the CEO power index. CEO_Power is the sum of CEO_Founder, CEO_Chair, H_CEO_OWN, and L_CEO_Tenure. H_CEO_OWN is equal to one if the CEO owns $10 \%$ or more share outstanding, and zero otherwise. L_CEO_Tenure is equal to one if the CEO's current tenure is longer than four years (sample median), and zero otherwise. The unreported control variables in Panels A-D are the same as those in Tables V, VII, VIII, and XI, respectively, except that CEO_Founder, CEO_Chair, CEO_OWN, and CEO_Tenure are dropped from the control variables. Definitions of all variables are provided in Table I. Robust standard errors reported in parentheses are clustered at the industry level in Panels A, C, and D and clustered at the firm level in Panel B. Coefficients marked with *, **, and *** are significant at $10 \%, 5 \%, 1 \%$, respectively.

Panel A: Bivariate Probit Model Estimation of Corporate Fraud

\begin{tabular}{|c|c|c|}
\hline & Fraud & Detect|Fraud \\
\hline VARIABLES & (1) & (2) \\
\hline \multirow[t]{2}{*}{ CEO_Power } & 0.155 & -0.100 \\
\hline & (0.138) & (0.116) \\
\hline Year Dummies & $\mathrm{Y}$ & $\mathrm{Y}$ \\
\hline Observations & 7,871 & 7,871 \\
\hline Prob $>\mathrm{Chi}^{2}$ & 0.000 & 0.000 \\
\hline log likelihood & -1266 & -1266 \\
\hline
\end{tabular}

Panel B: Forced CEO Turnover-Fraud Sensitivity

\begin{tabular}{|c|c|c|}
\hline \multirow[t]{3}{*}{ VARIABLES } & \multicolumn{2}{|c|}{ Forced_CEO_Turnover } \\
\hline & OLS & Clogit \\
\hline & (1) & $(2)$ \\
\hline \multirow[t]{2}{*}{ Fraud_t-3-t *CEO_Power } & -0.029 & 0.217 \\
\hline & $(0.018)$ & $(0.649)$ \\
\hline \multirow[t]{2}{*}{ CEO_Power } & $-0.018 * * *$ & $-0.932 * * *$ \\
\hline & $(0.005)$ & (0.195) \\
\hline \multirow[t]{2}{*}{ Fraud ${ }_{t-3-t}$} & $0.069 *$ & 0.242 \\
\hline & $(0.036)$ & $(0.775)$ \\
\hline Year FE (Dummies) & $\mathrm{Y}$ & $\mathrm{Y}$ \\
\hline Firm FE & $\mathrm{Y}$ & $\mathrm{N}$ \\
\hline Observations & 7,978 & 1,214 \\
\hline Adjusted $\mathrm{R}^{2}$ & 0.082 & \\
\hline Wald & & 488.9 \\
\hline
\end{tabular}

Panel C: Fraud Detection Duration

\begin{tabular}{|c|c|c|}
\hline \multirow[t]{2}{*}{ VARIABLES } & \multicolumn{2}{|c|}{ Ln(Duration_Day) } \\
\hline & $(1)$ & $(2)$ \\
\hline \multirow[t]{2}{*}{ CEO_Power } & $0.087^{*}$ & $-0.248 * * *$ \\
\hline & $(0.049)$ & $(0.063)$ \\
\hline Industry Dummies & $\mathrm{Y}$ & $\mathrm{Y}$ \\
\hline Observations & 296 & 296 \\
\hline Adjusted $\mathrm{R}^{2}$ & 0.284 & \\
\hline Wald & & 68208 \\
\hline \multicolumn{3}{|c|}{ Panel D: The Number of People Charged } \\
\hline \multirow[t]{2}{*}{ VARIABLES } & \multicolumn{2}{|c|}{ Ln(Num_Charged+1) } \\
\hline & \multicolumn{2}{|c|}{ (1) } \\
\hline \multirow[t]{2}{*}{ CEO_Power } & \multicolumn{2}{|c|}{0.032} \\
\hline & \multicolumn{2}{|c|}{$(0.037)$} \\
\hline Industry Dummies & \multicolumn{2}{|c|}{$\mathrm{Y}$} \\
\hline Observations & \multicolumn{2}{|c|}{303} \\
\hline Adjusted $\mathrm{R}^{2}$ & \multicolumn{2}{|c|}{0.100} \\
\hline
\end{tabular}

